Supporting Information

\title{
Involving Single-Atom Silver(0) in Selective Dehalogenation by AgF under Visible-Light Irradiation
}

Wenli Wu, Enxin Cui, Yun Zhang, Chen Zhang, Feng Zhu, Chen-Ho Tung and Yifeng Wang*

Key Lab for Colloid and Interface Science of Ministry of Education, School of Chemistry and Chemical Engineering, Shandong University, Jinan 250100, P. R. China

Corresponding author email: yifeng@sdu.edu.cn

\section{Table of contents}

1. Experimental Section

1.1 Chemicals

1.2 Instruments

1.3 Light sources

1.4 Methods

1.5 Single crystal X-ray crystallography (SC-XRD)

2. Supplementary data and discussion

Figure S1. Kinetics of the reactions

Table S1. Effects of the experimental parameters on the yields

Table S2. Modification of experimental parameters

Table S3. Effects of added eqs of AgF on the reactions

Table S4. Effects of added amount of $\mathrm{CsF}$ on reaction $\mathbf{1} \rightarrow \mathbf{1 b}$

Figure S2. Leaching tests

Figure S3. The recycling experiments of the AgF/visible-light system

Figure S4. XPS and PXRD data of the various samples

Figure S5. TEM images of $\mathrm{Ag}(0) / \mathrm{AgI}$

Discussion on the assignment of the $g=2.003$ peak

Figure S6. Additional ESR spectra of $\mathrm{Ag}(0) / \mathrm{AgI}$

Figure S7. The ESR spectra of Ag species in literature

Figure S8. Characterization of $\mathrm{Ag}(0)$ supported on BEA zeolite

Figure S9. ESR of bare $\mathrm{SiO}_{2}, \mathrm{Ag}_{1} / \mathrm{SiO}_{2}$, bare $\mathrm{GO}$ and $\mathrm{Ag}_{1} / \mathrm{GO}$

Figure S10. The low-resolution TEM images of $\mathrm{Ag}_{1} / \mathrm{GO}$ and $\mathrm{Ag}_{1} / \mathrm{SiO}_{2}$

Figure S11. The AC-STEM image of $\mathrm{Ag}_{1} / \mathrm{GO}$

Figure S12. A full AC-STEM image of $\mathrm{Ag}(0) / \mathrm{SiO}_{2}$

Figure S13. More TEM images of recycled-AgF

Figure S14. The ESR spectrum of phenylsilver

Figure S15. Determination of the PMP-TEMPO adduct

Figure S16. Determination of the byproducts in the hydrodehalogenation reaction

Figure S17. Kinetic isotope effects

3. Characterization data of the products

4. Spectra of the compounds

5. References 


\section{Experimental Section}

1.1 Chemicals. $\mathrm{SiO}_{2}$ (Alfa Aesar, surface area $\left.=300-350 \mathrm{~m}^{2} \mathrm{~g}^{-1}\right)$ and $\mathrm{TiO}_{2}($ Degussa P25) were obtained from Specialty Chemicals (Shanghai) Co Ltd. AgI (99\%), $\mathrm{AgNO}_{3}(\mathrm{AR}, 99 \%)$ and $\mathrm{CsF}(99 \%)$ were purchased from Xiya Reagent. AgF, aryl halides, heterocyclic iodides and perfluoroiodothane (purity $>98 \%$ ) were purchased from Shanghai Boka-chem Tech Inc and used as received. The commercially unavailable substrates, including alkenyl iodides and alkynyl iodides were prepared in the lab of which the procedures and the characterizations are described later. The radical scavenger, 2,2,6,6-tetramethylpiperidine-1-oxyl (TEMPO), was obtained from J\&K Scientific. Graphene oxide (GO) was synthesized from natural graphite powder following the modified Hummers method and obtained as an aqueous solution $\left(1.45 \mathrm{~g} \mathrm{~L}^{-1}\right)$ without any surfactant. ${ }^{1}$ The solvents, like benzene, toluene, $p$-xylene, 1,4-difluorobenzene, DCM and acetonitrile, were of analytical grade and purified by distillation using calcium hydride before use. Deionized water $(18.2 \mathrm{M} \Omega \cdot \mathrm{cm})$ was used for preparation of the materials.

1.2 Instruments. STEM was performed on a JEM-ARM 200F instrument (JEOL, Japan) operating at $200 \mathrm{kV}$, equipped with a spherical aberration corrector (CEOS Gmbh). The images were recorded with an HAADF detector (70 - $250 \mathrm{mrad})$ and ABF detector (11-25 mrad). High-resolution TEM images were taken using a JEM-2100F instrument (JEOL, Japan) operating at $200 \mathrm{kV}$. Low-resolution TEM images were taken using a JEM-1011 instrument (JEOL, Japan) operating at $100 \mathrm{kV}$. Scanning electron microscopic images were obtained using a Bruker SH3000 SEM attached with an energy dispersive spectrometer (EDS). ${ }^{1} \mathrm{H}$ NMR and ${ }^{13} \mathrm{C}$ NMR spectra were obtained using the Bruker $500 \mathrm{MHz}$ Fourier transform NMR spectrometer. Gas chromatography-mass spectroscopy (GCMS) measurements were conducted using Shimadzu QP2010 SE system equipped with a capillary column (HP-5, $30 \mathrm{~m} \times 0.32 \mathrm{~mm} \times 0.5 \mu \mathrm{m}$ ). GC was conducted with a GC-7900 instrument (Techcomp, China) equipped with an FID detector and a capillary column $(\mathrm{TM}-5,60 \mathrm{~m} \times 0.32 \mathrm{~mm} \times 0.5 \mu \mathrm{m})$. Column chromatography for purification of the organic compounds was performed using 200-300 mesh silica according to standard techniques. Single crystal X-ray diffraction data were collected on a Bruker SMART APEX II diffractometer at 173 K. Powder X-ray diffraction (PXRD) was recorded on a Bruker D8 Advance X-ray diffraction instrument. X-ray photoelectron spectroscopy (XPS) measurements were conducted using a ThermoFisher Scientific ESCALAB 250 system. ESR measurements were performed on a JOEL X320 instrument. The field and the signal intensity were calibrated using the Mn marker of the instrument. Lyophilization was performed using a domestic instrument. Concentration of $\mathrm{I}^{-}$was measured using the ion specific electrode method with an ion meter (model PXSJ-216; INESA Scientific Instrument Co., Ltd) in aqueous solutions.

1.3 Light sources. The single-wavelength LED lamps were assembled using plant grow light LED chips of which the spectra are shown later. A Xenon lamp (300 W input; model CEL-HFX300E7; Au light Co., China) was used as the solar simulator. The light intensity irradiated on the reaction vial was measured using a light intensity meter 
(model CEL-NP2000-10; Au light Co). The values for the 395, 425, 450 and $475 \mathrm{~nm}$ LED, Xenon lamp were 112, 153, 164 and $102 \mathrm{~mW} \mathrm{~cm}^{-2}$, respectively. The spectra of the LED lamps are shown as follows:

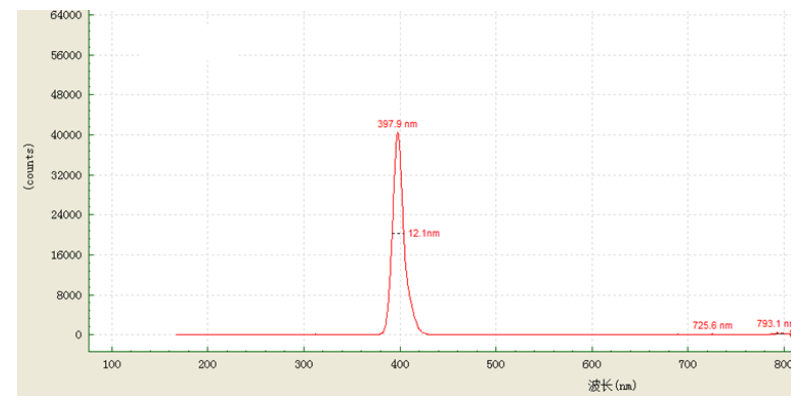

the $395 \mathrm{~nm}$ lamp, $398 \pm 6 \mathrm{~nm}$

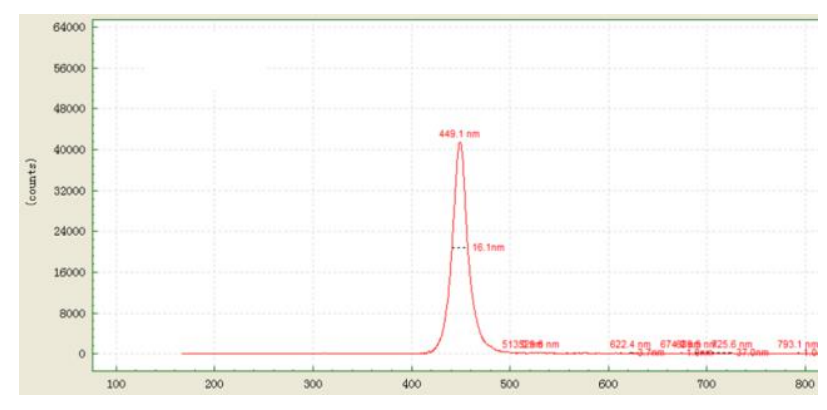

the $450 \mathrm{~nm}$ lamp, $449 \pm 8 \mathrm{~nm}$

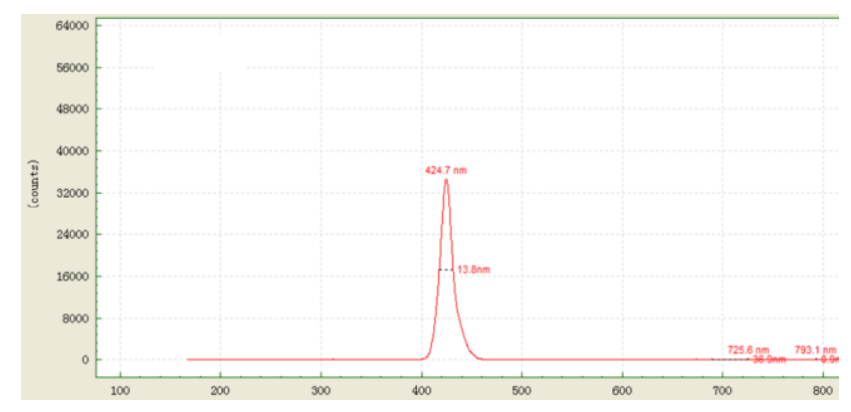

the $425 \mathrm{~nm}$ lamp, $425 \pm 7 \mathrm{~nm}$

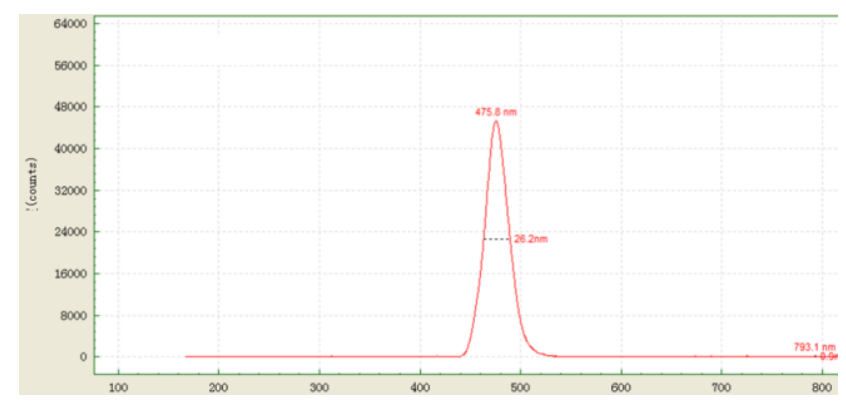

the $475 \mathrm{~nm}$ lamp, $475 \pm 13 \mathrm{~nm}$

\subsection{Methods}

Preparation of $\mathbf{A g ( 0 )} / \mathrm{SiO}_{2}$. A mixture of $50 \mathrm{mg}$ of recycled-AgF and $200 \mathrm{mg}$ of $\mathrm{SiO}_{2}$ was added to $50 \mathrm{~mL}$ of $\mathrm{Na}_{2} \mathrm{~S}_{2} \mathrm{O}_{3}(1.0 \mathrm{M})$ under stirring. According to the composition of recycled-AgF, this protocol should afford a sample with ca. $6.0 \mathrm{wt} \%$ of $\operatorname{Ag}(0)$. The resultant black powder was isolated by centrifugation and washed 2 more times using $50 \mathrm{~mL}$ of the $\mathrm{Na}_{2} \mathrm{~S}_{2} \mathrm{O}_{3}$ solution. Afterwards, $\mathrm{Ag}(0) / \mathrm{SiO}_{2}$ was isolated by centrifugation, washed 10 times with water and air dried. A representative SEM image and the EDS results are shown below. The bright small particles in the SEM image are silver(0) nanoparticles. EDS confirms the complete removal of AgI.
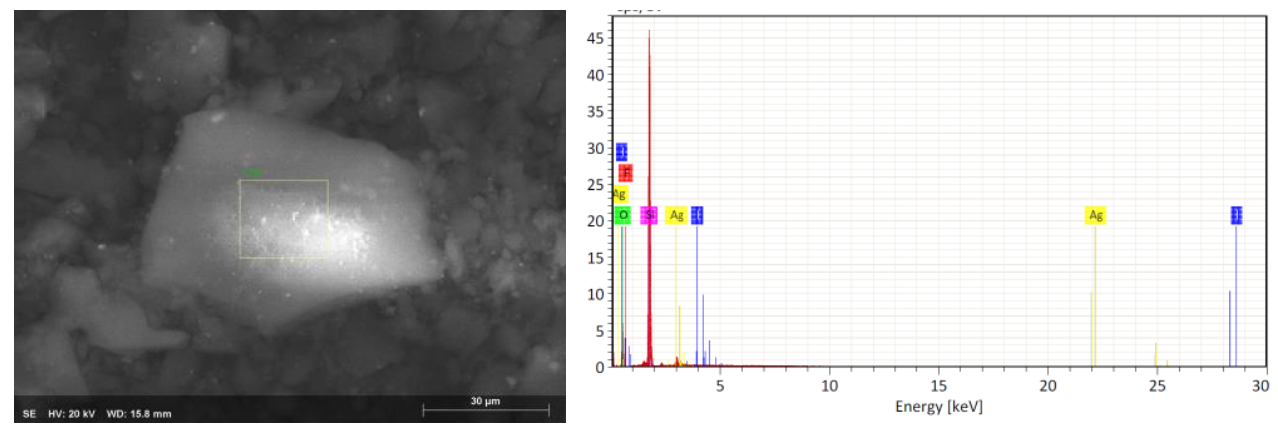

$\begin{array}{lll}\text { Element } & \text { Wt } \% & \text { Atom\% } \\ \mathrm{O} & 40.76 & 55.67 \\ \mathrm{Si} & 55.44 & 43.13 \\ \mathrm{Ag} & 4.6 & 0.93 \\ \mathrm{~F} & 0.22 & 0.25 \\ \mathrm{I} & 0.09 & 0.01\end{array}$


Preparation of $\mathbf{A g ( 0 ) / A g I . ~ I n ~ a ~} 50 \mathrm{~mL}$ beaker, ca. $100 \mathrm{mg}$ of recycled-AgF was dispersed in $20 \mathrm{~mL}$ of ammonia (5 $\mathrm{M})$ for ca. $2 \mathrm{~h}$ under stirring to dissolve AgF. This process was repeated three times. The black residue, i.e., $\mathrm{Ag}(0) / \mathrm{AgI}$, was isolated by centrifugation, washed 10 times with water and air dried. Yield was ca. $30 \mathrm{mg}$. According to the measurements shown later, the loading of $\mathrm{Ag}(0)$ and $\mathrm{AgI}$ were $24 \mathrm{wt} \%$ and $76 \mathrm{wt} \%$, respectively.

Preparation of $\mathbf{A g}_{1} / \mathrm{SiO}_{2}$ and $\mathbf{A g}_{1} / \mathbf{G O}$. The as-prepared, phase-pure $\mathrm{Ag}_{1} / \mathrm{GO}$ and $\mathrm{Ag}_{1} / \mathrm{SiO}_{2}$ samples were prepared by an "iced-photochemical reduction" method following the method by Wei et al. ${ }^{2}$ Wei et al. used this protocol to disperse isolated metal-atoms on the surfaces of various materials like MWCNT and used HAADF-STEM to characterize the samples. Using this method, both metal( 0$)$ NPs and isolated metal(0) atoms were generated. In the present study, we optimized the preparation temperature, the ratio of support to $\mathrm{AgNO}_{3}$ and the irradiation time to load SAAg on surfaces of $\mathrm{SiO}_{2}$ and GO. In detail, a $200 \mathrm{~mL}$ beaker was half immersed in a thermostatic bath at $30{ }^{\circ} \mathrm{C}$. A $5 \mathrm{~mL}$ aqueous dispersion of $\mathrm{SiO}_{2}\left(5 \mathrm{~g} \mathrm{~L}^{-1}\right)$ or $\mathrm{GO}\left(1.45 \mathrm{~g} \mathrm{~L}^{-1}\right)$ was prepared by ultrasonication and then added to the beaker. The dispersion was frozen quickly. Afterwards, a certain amount of aqueous $\mathrm{AgNO}_{3}$ (e.g., 5 $\mathrm{mL}, 7.5 \mathrm{~mL}, 10 \mathrm{~mL} ; 0.3 \mathrm{~g} \mathrm{~L}^{-1}$ ) was also added and frozen. The ice was irradiated by the 100-W $395 \mathrm{~nm}$ LED from the top for 6 hours at $-30^{\circ} \mathrm{C}$. The loaded amount of $\mathrm{Ag}(0)$ was controlled by the volume of the added $\mathrm{AgNO}_{3}$ solution, assuming all the $\mathrm{Ag}^{+}$was converted to $\operatorname{Ag}(0)$ on the support. After irradiation, the ice was melt at room temperature in the dark under magnetic stirring for $30 \mathrm{~min}$. The $\mathrm{Ag}_{1} /$ support sample was collected by centrifugation, washed thrice with water (no $\mathrm{Ag}^{+}$residue remained by $\mathrm{Cl}^{-}$test) and dried under vacuum at room temperature. TEM images of $\mathrm{Ag}_{1} / \mathrm{GO}$ and $\mathrm{Ag}_{1} / \mathrm{SiO}_{2}$ are shown later.

Preparation of AgNPs using the Turkevich ${ }^{3}$ method. A $60 \mathrm{~mL}$ of $1.0 \mathrm{mM} \mathrm{AgNO}_{3}$ solution was boiled in a beaker by a hot plate. To this boiling solution was added dropwise $6.0 \mathrm{~mL}$ of $10 \mathrm{mM}$ trisodium citrate. Water was added as necessary during the heating process. After $30 \mathrm{~min}$ the boiling solution color became light golden, indicating formation of Ag colloid. The solution was then cooled naturally to room temperature. According to the TEM images shown below, the size of the NPs ranges from $5-35 \mathrm{~nm}$. Then, the colloid was centrifuged to give a precipitate which was dried by lyophilization.
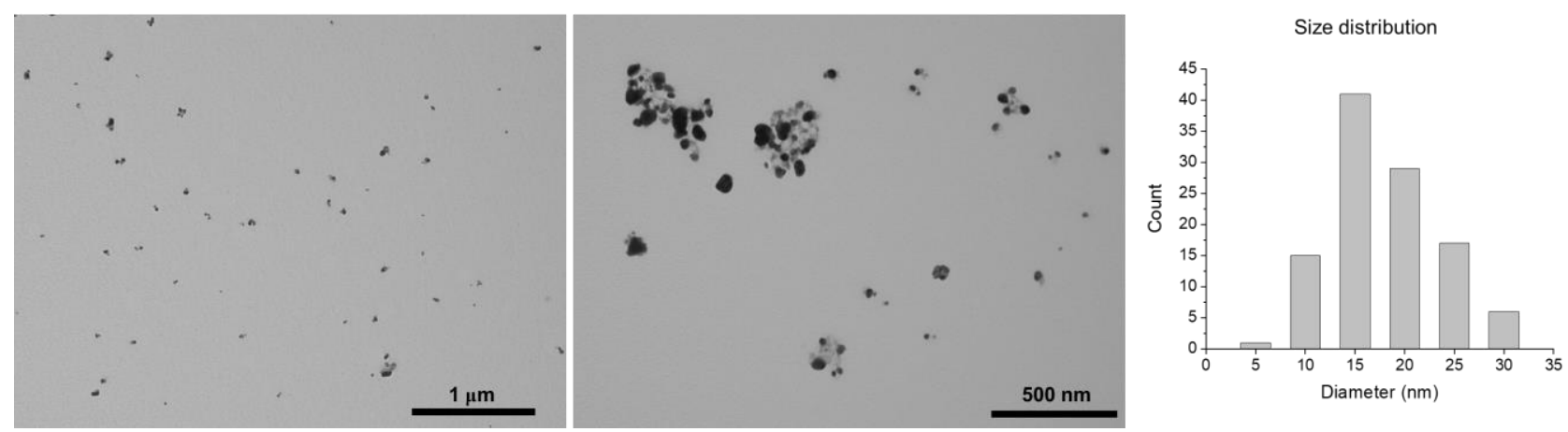

Preparation of AgNPs/TiO $2, \mathbf{A g N P s} / \mathrm{SiO}_{2}$ and AgNPs/AgI. The protocol involves the adsorption of $\mathrm{AgNO}_{3}$ on the surfaces of $\mathrm{TiO}_{2}, \mathrm{SiO}_{2}$ or $\mathrm{AgI}$ followed by UV photolysis following the literature. ${ }^{4} 1.0 \mathrm{~g}$ of $\mathrm{TiO}_{2}\left(\right.$ or $\left.\mathrm{SiO}_{2}, \mathrm{AgI}\right)$ 
was dispersed in $100 \mathrm{~mL}$ of water containing $15.7 \mathrm{mg} \mathrm{AgNO} 3(1.0 \mathrm{wt} \%)$ and $400 \mu \mathrm{L}$ of methanol. After purging with $\mathrm{N}_{2}$, the solution was magnetically stirred in the dark for $30 \mathrm{~min}$ and then irradiated with the $300-\mathrm{W}$ Xe lamp for $120 \mathrm{~min}$. The resultant suspension was centrifuged to give a precipitate, which was washed 5 times with water. The wet precipitate was dried at $80^{\circ} \mathrm{C}$ in an oven under air atmosphere and ground into a powder. According to the HR-TEM images of AgNPs/SiO 2 (see below), the diameter of the AgNPs ranges $2-25 \mathrm{~nm}$. ESR measurements indicated no SAAg existed in $\mathrm{AgNPs} / \mathrm{TiO}_{2}, \mathrm{AgNPs} / \mathrm{SiO}_{2}$ or $\mathrm{AgNPs} / \mathrm{AgI}$.
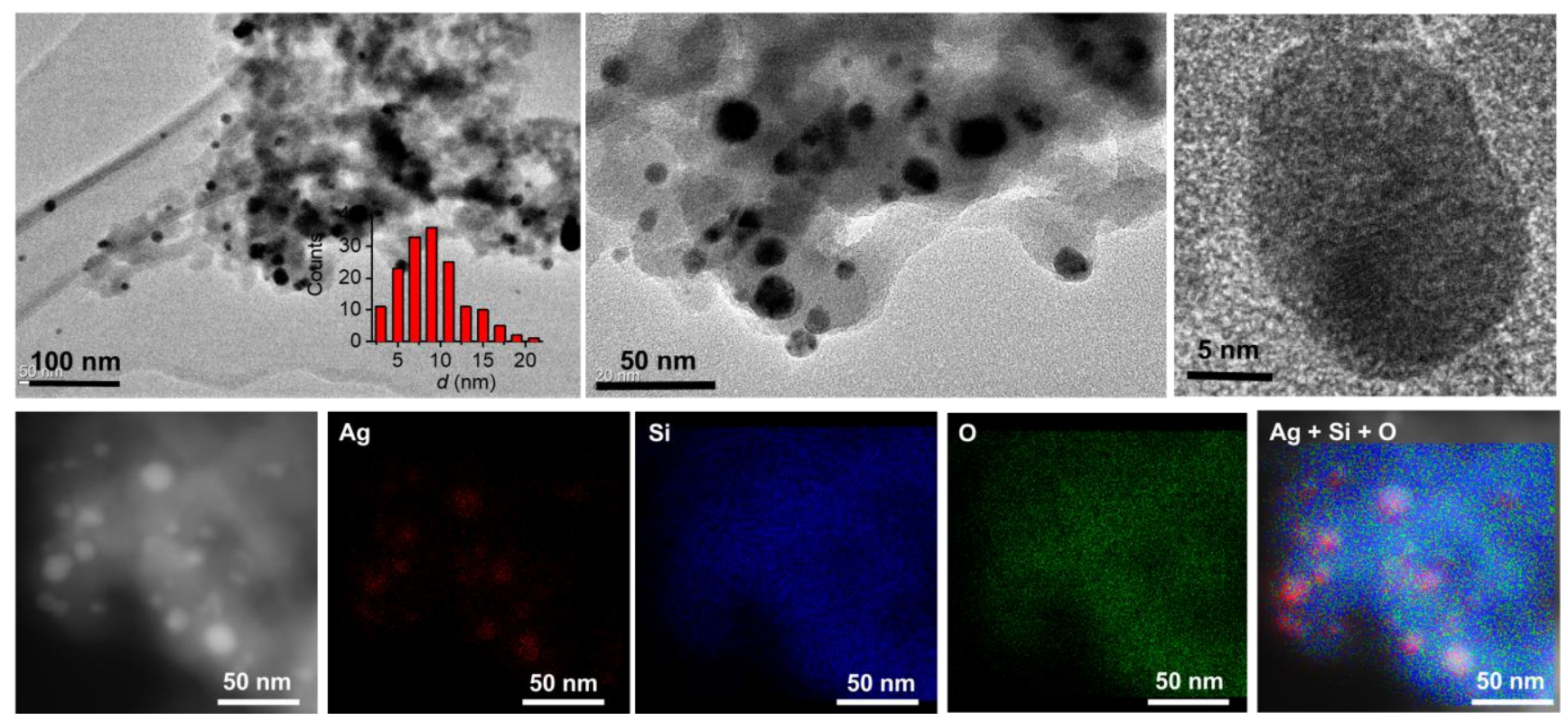

Quantification of [SAAg] using ESR. A $10 \mathrm{~mL}$ of TEMPO/ $\mathrm{CH}_{2} \mathrm{Cl}_{2}$ solution $\left(0.5-4.0 \times 10^{-4} \mathrm{~g} \mathrm{~L}^{-1}\right)$ was prepared and mixed thoroughly with $10 \mathrm{~mL}$ of solid $\mathrm{SiO}_{2}$ powder $(\sim 400 \mathrm{mg})$. This dispersion was concentrated by rotary evaporation to give a solid sample (sample A). Volume of the TEMPO/ $\mathrm{CH}_{2} \mathrm{Cl}_{2}$ solution varied so that the amount of TEMPO on $\mathrm{SiO}_{2}$ could be controlled. A series of the solid samples were used for ESR measurements to give a calibration curve, which was used for quantification of [SAAg] later. Then, a certain amount (e.g., $29 \mathrm{mg}$ ) of the powder sample, e.g., $\mathrm{Ag}(0) / \mathrm{AgI}$, was mixed uniformly with $0.54 \mathrm{~mL}$ (21.6 mg) of $\mathrm{SiO}_{2}$ for ESR measurement. The total volume of the final solid sample was assumed to be $0.54 \mathrm{~mL}$ as well. The peak area of the $\mathrm{g}=2.003$ peak of this sample was used to calculate the concentration of SAAg in $\mathrm{Ag}(0) / \mathrm{AgI}$.

Quantification of AgI and Ag(0) in Ag(0)/AgI. $20 \mathrm{mg} \mathrm{Ag(0)/AgI} \mathrm{was} \mathrm{dispersed} \mathrm{in} \mathrm{ca.} 30 \mathrm{~mL}$ of $1.0 \mathrm{M} \mathrm{Na}_{2} \mathrm{~S}_{2} \mathrm{O}_{3}$ in a $100 \mathrm{~mL}$ volumetric flask. After soaking for ca. $2 \mathrm{~h}$, water was added to the volume marker. The concentration of $\mathrm{I}^{-}$in the solution was measured using an ion meter equipped with an iodide specific electrode. The amount of $\mathrm{I}^{-}$in the solution was then used to calculate the content of $\mathrm{AgI}$ in $\mathrm{Ag}(0) / \mathrm{AgI}$. Accordingly, the content of $\operatorname{Ag}(0)$ could be estimated.

Protocol for the quantification of $\mathbf{A g ( 0 )}$ in Table 3. After the reaction completed, organic phase was removed. The residual was in sequence washed with DCM three times, washed with $20 \mathrm{~mL}$ of ammonia (5 M) for ca. $2 \mathrm{~h}$ 
under stirring to dissolve $\mathrm{AgF}$, washed with water three times and air dried. Then, the solid material was socked in $0.3 \mathrm{M} \mathrm{HNO}_{3}(5 \mathrm{~mL})$ for ca. $5 \mathrm{~h}$ to dissolve $\mathrm{Ag}(0)$ in a $100 \mathrm{~mL}$ flask. Afterwards, $0.5 \mathrm{wt} \%$ aqueous $\mathrm{KNO}_{3}$ was added to the volume marker. The concentration of $\mathrm{Ag}^{+}$in the solution was measured using an ion meter equipped with an $\mathrm{Ag}^{+}$specific electrode.

General procedure for the dehalogenation reactions. The solvents were routinely purified by distillation in order to obtain repeatable outcome and to understand the details of mechanism. In a $10 \mathrm{~mL}$ pyrex reaction vial, $20 \mathrm{mg}$ organic halide and $20 \mathrm{mg}$ material were dispersed in $2.0 \mathrm{~mL}$ of solvent. For the arylation of the halides, benzene, fluorobenzene, 1,4-difluorobenzene and $p$-xylene which are liquids of low viscosity were used directly as both the aryl sources and the solvents. Solid naphthalene was used by dissolving 10 eqs of it in $\mathrm{MeCN}$. For the hydrogenation of the organic halides, MeCN was used as the solvent. For all reactions, $n-\mathrm{C}_{14} \mathrm{H}_{30}$ was also added as an internal standard of gas chromatography as necessary. The vial was sealed with a butyl rubber stopper and then purged with $\mathrm{N}_{2}$. The vial was half immersed in a water bath (to maintain room temperature) and irradiated from the side (see the scheme below). After every certain time, ca. $1.0 \mu \mathrm{L}$ of the solution was withdrawn and analyzed with GC or GCMS to check the products and the reaction kinetics. After complete conversion of the halide, the dispersion was filtered with celite to remove the insoluble material and then the filtrate was concentrated to give a residue which was purified by column chromatography for further analysis (e.g., GC-MS and NMR).

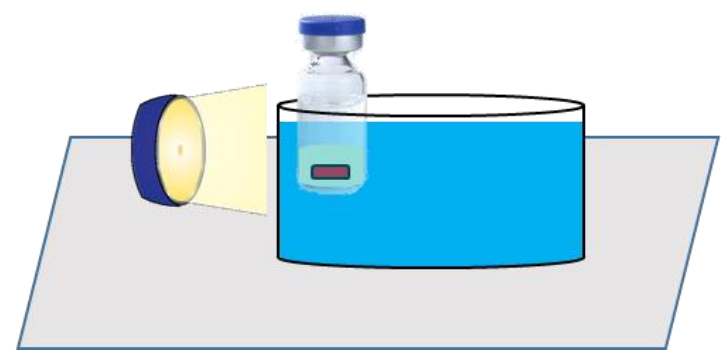

The experimental setup for the photo-reaction

The method for quantum yield estimations. The quantum yields were estimated following the previous method. ${ }^{5}$ It was assumed that all the incident photons reaching the solution were harvested. It was also assumed that the LEDs are monochromatic. The reaction cross section is estimated to be $4 \mathrm{~cm}^{2}$ for the $2-\mathrm{mL}$ reaction. The total quantum yield, $\eta$, is defined as:

$$
\eta=\frac{\text { the amount of reacted } 1}{\text { the number of photons }}
$$

Notably, the above calculations should underestimate the quantum yield values.

Method for in situ ESR studies. $20 \mathrm{mg}(0.086 \mathrm{mmol})$ 4-methoxybenzene iodide and $20 \mathrm{mg}$ of the material were grinding evenly for use. Then the solid mixture $\left(10 \mathrm{mg}\right.$ ) and benzene (containing $n-\mathrm{C}_{14} \mathrm{H}_{30}$ ) were added to a $1.0 \mathrm{~mm}$ capillary in a glovebox. The capillary was sealed with plasticine and then enclosed in $5 \mathrm{~mm}$ NMR tube. Finally, the 
NMR tube was sealed with wax after being taken out of the glovebox. To carry out the photo-driven reaction, the sample was irradiated with LED from the side. After certain intervals, the sample was directly taken for ESR measurements. The loading of SAAg was calculated using the calibration curve of TEMPO. After the reaction, the conversion of 4-methoxybenzene iodide and the yield of biphenyl were quantified using GC.

Procedure of leaching tests. After certain time, the reaction dispersion was allowed to stand for ca. 10 min for sedimentation. The supernatant was filtered with $0.22 \mu \mathrm{M}$ membrane filters to remove the nanoparticles. Although the sizes of SAAg and AgNPs are much smaller than that of the membrane pore, they could be readily removed since they are attached on the surfaces of $\mathrm{AgF}$ and/or $\mathrm{AgI}$. Then, the filtrate was irradiated under standard conditions in a new reaction vial. The reaction kinetic was followed using GC.

1.5 Single crystal X-ray crystallography (SC-XRD). Crystals of 31a (as well as 41) appropriate for X-ray diffraction were obtained by vapor diffusion of petroleum ether into an ethyl acetate solution saturated with 31a. However, this method was not suitable for 33a. After many efforts, it was found out that vapor diffusion of ethanol into a concentrated ethyl acetate solution of 33a was able to produce high-quality crystals. Single crystal X-ray diffraction was performed on a Bruker SMART APEX II diffractometer using Cu K $\alpha$ radiation $(\lambda=1.54184 \AA)$ at 173 K. Structure solution and refinement were performed using the Shelx package embedded in the Olex 2 software. Hydrogen atoms were added theoretically. Crystallographic data are summarized as follows. 


\begin{tabular}{|c|c|c|c|}
\hline & Compound 31a & Compound 33a & Compound 41 \\
\hline \multicolumn{4}{|l|}{ Structure } \\
\hline \multicolumn{4}{|l|}{$\begin{array}{l}\text { Thermal ellipsoidal repre- } \\
\text { sentation of the structures } \\
\text { (50\% probability) }\end{array}$} \\
\hline Empirical formula & $\mathrm{C}_{16} \mathrm{H}_{12} \mathrm{~N}_{2}$ & $\mathrm{C}_{15} \mathrm{H}_{17} \mathrm{NO}_{4}$ & $\mathrm{C}_{16} \mathrm{H}_{12} \mathrm{~N}_{2}$ \\
\hline Formula weight & 232.28 & 275.29 & 232.29 \\
\hline Temperature, $\mathrm{K}$ & $173.00(10)$ & $173.00(10)$ & $172.98(10)$ \\
\hline Crystal system & orthorhombic & orthorhombic & monoclinic \\
\hline Space group & Pna2 $2_{1}$ & Pna2 $2_{1}$ & $\mathrm{P} 2_{1} / \mathrm{n}$ \\
\hline $\mathrm{a}, \AA$ & $7.5559(5)$ & $9.7201(4)$ & $7.8048(3)$ \\
\hline $\mathrm{b}, \AA$ & $13.9087(12)$ & $26.2838(10)$ & $5.9454(3)$ \\
\hline $\mathrm{c}, \AA$ & $11.4271(7)$ & $5.4483(2)$ & $13.2408(5)$ \\
\hline$\alpha,{ }^{\circ}$ & 90 & 90 & 90 \\
\hline$\beta, \circ$ & 90 & 90 & $92.593(4)$ \\
\hline$\gamma,{ }^{\circ}$ & 90 & 90 & 90 \\
\hline Volume, $\AA^{3}$ & $1200.91(15)$ & 1391.94(9) & $613.78(5)$ \\
\hline Z & 4 & 4 & 4 \\
\hline$\rho_{\text {calc }}, \mathrm{g} \mathrm{cm}^{-3}$ & 1.285 & 1.314 & 1.257 \\
\hline$\mu, \mathrm{mm}^{-1}$ & 0.597 & 0.790 & 0.584 \\
\hline $\mathrm{F}(000)$ & 488.0 & 584.0 & 244.0 \\
\hline Radiation & $\mathrm{Cu} \mathrm{K \alpha}(\lambda=1.54184)$ & $\mathrm{Cu} \mathrm{K} \alpha(\lambda=1.54184)$ & $\mathrm{Cu} \mathrm{K} \alpha(\lambda=1.54184)$ \\
\hline $\begin{array}{l}2 \theta \text { range for data collec- } \\
\text { tion, }{ }^{\circ}\end{array}$ & 10.018 to 151.762 & 6.726 to 162.704 & 12.916 to 152.706 \\
\hline Reflections collected & 3443 & 4450 & 3467 \\
\hline Independent reflections & $\begin{array}{l}1806\left[R_{\text {int }}=0.0596,\right. \\
\left.R_{\text {sigma }}=0.0630\right]\end{array}$ & $\begin{array}{l}2213\left[\mathrm{R}_{\text {int }}=0.0454, \mathrm{R}_{\text {sigma }}=\right. \\
0.0486]\end{array}$ & $\begin{array}{l}1219\left[R_{\text {int }}=0.0355, R_{\text {sigma }}=\right. \\
0.0413]\end{array}$ \\
\hline Data/restraints/parameters & $1806 / 1 / 163$ & $2213 / 1 / 83$ & $1219 / 0 / 82$ \\
\hline Goodness-of-fit on $\mathrm{F}^{2}$ & 1.791 & 1.114 & 1.055 \\
\hline Final $R$ indexes $[I>=2 \sigma(I)]$ & $\begin{array}{l}\mathrm{R}_{1}=0.1656, \quad w \mathrm{R}_{2}= \\
0.3673\end{array}$ & $\mathrm{R}_{1}=0.0495, \mathrm{wR}_{2}=0.1244$ & $\mathrm{R}_{1}=0.0523, \mathrm{wR}_{2}=0.1393$ \\
\hline Final $\mathrm{R}$ indexes [all data] & $\begin{array}{l}\mathrm{R}_{1}=0.1727, \quad \mathrm{wR}_{2}= \\
0.3940\end{array}$ & $\mathrm{R}_{1}=0.0598, \mathrm{wR}_{2}=0.1435$ & $\mathrm{R}_{1}=0.0648, \mathrm{wR}_{2}=0.1581$ \\
\hline Largest diff. peak/hole, e $\AA^{-3}$ & $1.49 /-0.44$ & $0.30 /-0.21$ & $0.16 /-0.24$ \\
\hline
\end{tabular}




\section{Supplementary data and discussion}
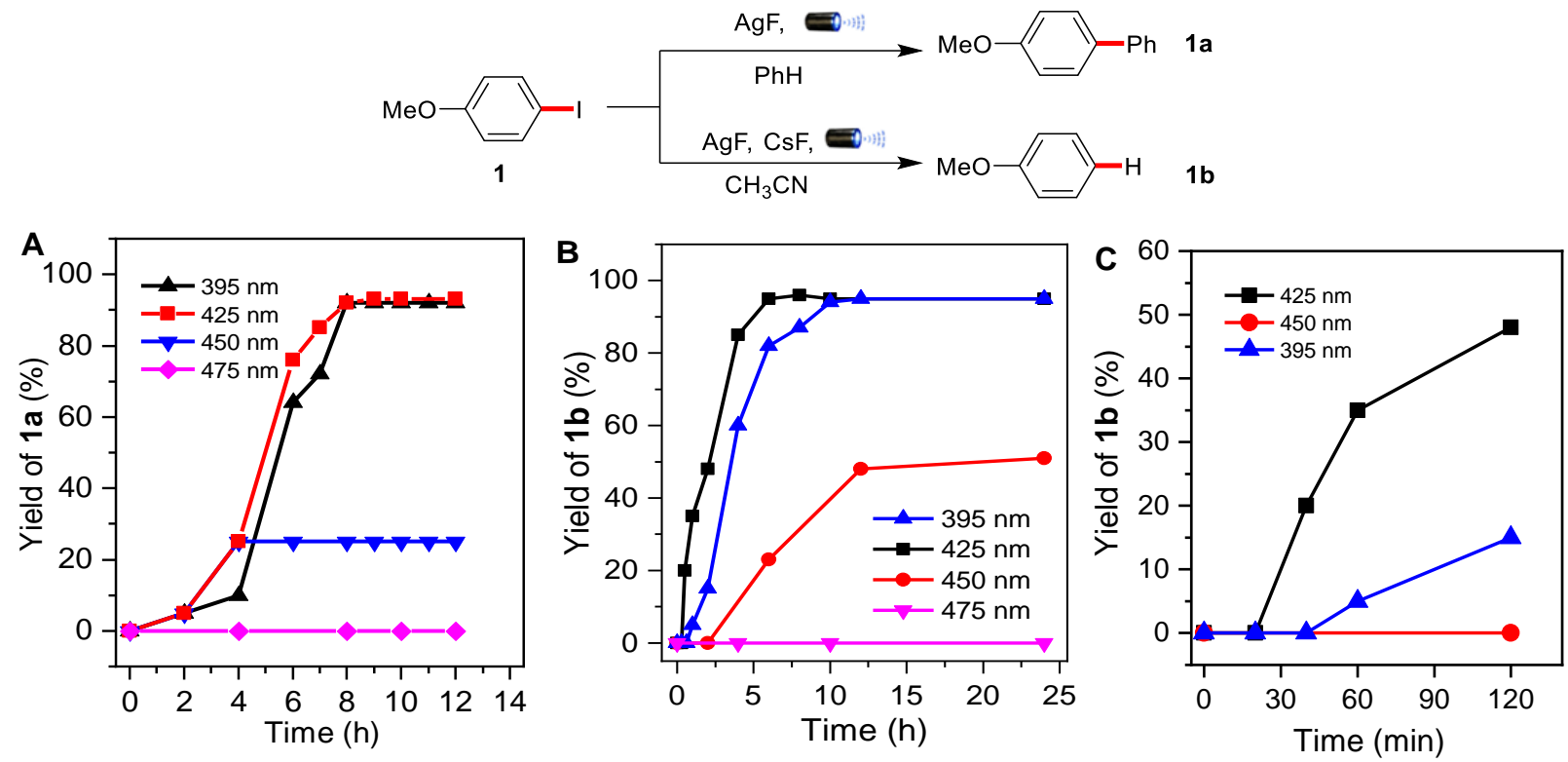

Figure S1. (A) The formation kinetics of 1a. An induction period of ca. $2 \mathrm{~h}$ was observed. Other conditions: 1, 20 $\mathrm{mg}$; AgF, $20 \mathrm{mg} ; 2.0 \mathrm{~mL}$ benzene as the solvent; $\mathrm{N}_{2}$; r.t. (B) and (C) The formation kinetics of $\mathbf{1 b}$. Panel C shows the magnified view of panel B highlighting the induction period. Other conditions: 1, $20 \mathrm{mg}$; AgF, $20 \mathrm{mg}$; CsF, 40 $\mathrm{mg} ; \mathrm{MeCN}, 2.0 \mathrm{~mL} ; \mathrm{N}_{2}$. The yields were determined by GC using $n-\mathrm{C}_{14} \mathrm{H}_{30}$ as the internal standard.

Table S1. Effects of the experimental parameters on the yields

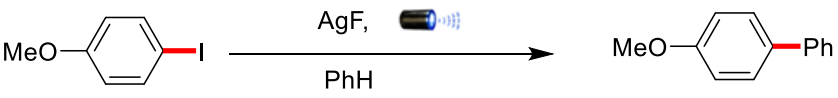

$1 \mathrm{a}$

\begin{tabular}{llll}
\hline Entry & Change from the standard conditions & Conversion of 1 (\%) & Yield of 1a (\%) \\
\hline 1 & no change & 100 & 92 \\
2 & $\mathrm{O}_{2}$ & 0 & 0 \\
3 & no AgF & 0 & 0 \\
4 & dark & 0 & 0 \\
5 & dark, $80^{\circ} \mathrm{C}$ & 0 & 0 \\
6 & $395 \mathrm{~nm} \mathrm{LED}$ & 100 & 92 \\
7 & $450 \mathrm{~nm}$ LED & 36 & 22 \\
8 & $300 \mathrm{~W}$ Xenon lamp & 82 & 78 \\
9 & $475 \mathrm{~nm}$ LED & 0 & 0 \\
10 & methanol, 10 eq & 100 & 68 \\
11 & ethanol, 10 eq & 100 & 55 \\
12 & water, 100 eq & 100 & 92 \\
\hline
\end{tabular}

${ }^{a}$ Standard conditions: 1, $20 \mathrm{mg}$; AgF, $20 \mathrm{mg} ; 2.0 \mathrm{~mL}$ benzene as the solvent; $425 \mathrm{~nm} \mathrm{LED} ; \mathrm{N}_{2}$; r.t.; 12 h. ${ }^{\mathrm{b}}$ Yields were determined by gas chromatography using $n-\mathrm{C}_{14} \mathrm{H}_{30}$ as the internal standard. 
Entry 2 infers that the reaction was readily quenched by $\mathrm{O}_{2}$. This, together with entries 10-11 which show a reducing solvent did not quench the reaction, rules out an oxidative deiodination mechanism proposed by He et al. ${ }^{6}$ Entry 12 shows that water did not affect the reaction, indicating the current protocol for coupling of halides with arenes is very robust.

Table S2. Modification of experimental parameters.

\begin{tabular}{|c|c|c|c|}
\hline Entry & Change from the standard conditions ${ }^{\mathrm{a}}$ & Conversion of $1(\%)$ & Yield of $\mathbf{1 b}(\%)$ \\
\hline 1 & no change & 100 & 99 \\
\hline 2 & no $\mathrm{AgF}$ & 0 & 0 \\
\hline 3 & no $\mathrm{CsF}$ & 36 & 36 \\
\hline 4 & $\mathrm{O}_{2}$ & 0 & 0 \\
\hline 5 & dark & 0 & 0 \\
\hline 6 & dark, $80^{\circ} \mathrm{C}$ & 0 & 0 \\
\hline 7 & $395 \mathrm{~nm}$ LED & 100 & $>99$ \\
\hline 8 & $450 \mathrm{~nm}$ LED & 53 & 51 \\
\hline 9 & visible light (Xenon lamp with $400 \mathrm{~nm}$ UV-cutoff filter) & 93 & 90 \\
\hline 10 & $300 \mathrm{~W}$ Xenon lamp & 100 & $>99$ \\
\hline 11 & $475 \mathrm{~nm}$ LED & 0 & 0 \\
\hline 12 & $\mathrm{CsCl}(220 \mathrm{mg}, 15 \mathrm{eq})+\mathrm{NaF}(54 \mathrm{mg}, 15 \mathrm{eq})$ & 100 & $>99$ \\
\hline 13 & $\mathrm{CsCl}(220 \mathrm{mg}, 15 \mathrm{eq})$ & 0 & 0 \\
\hline 14 & $\mathrm{NaF}(54 \mathrm{mg}, 15 \mathrm{eq})$ & 0 & 0 \\
\hline 15 & ascorbic acid, 2 eq & 60 & 58 \\
\hline 16 & $n-\mathrm{C}_{8} \mathrm{H}_{18}$ solvent & 55 & 42 \\
\hline 17 & tetrahydrofuran (THF) solvent & 95 & 92 \\
\hline 18 & methanol solvent & 100 & 20 \\
\hline 19 & solvent: MeCN $1 \mathrm{~mL}$ and water $1 \mathrm{~mL}$ & 100 & $>99$ \\
\hline
\end{tabular}

${ }^{a}$ Standard conditions: 1, $20 \mathrm{mg} ; \mathrm{AgF}, 20 \mathrm{mg}$; CsF, $40 \mathrm{mg}$; MeCN, $2.0 \mathrm{~mL} ; 425 \mathrm{~nm}$ LED; $\mathrm{N}_{2} ;$ r.t.; 12 h. ${ }^{\mathrm{b}}$ Yields were determined by $\mathrm{GC}$ using $n-\mathrm{C}_{14} \mathrm{H}_{30}$ as the internal standard.

Entry 4 indicates that the hydrodeiodination of 1 was readily quenched by an oxidizing agent like $\mathrm{O}_{2}$. Entries 15 and 18 indicate that a reducing agent did not quench the hydrodeiodination of $\mathbf{1}$. Therefore, hydrodeiodination of $\mathbf{1}$ should not follow an oxidative mechanism. Entries 12-14 infer that both $\mathrm{Cs}^{+}$and $\mathrm{F}^{-}$were essential of the hydrodeiodination of 1. Entries 16-19 indicate that the competent solvent is not limited to $\mathrm{MeCN}$ and meanwhile, water did not quench the hydrodeiodination reaction. 
Table S3. Effects of added eqs of $\mathrm{AgF}$ on the reactions

\begin{tabular}{lllll}
\hline Entry & Added AgF (mg) & Added AgF (eqs) & $\begin{array}{l}\text { Reaction } \mathbf{1} \rightarrow \mathbf{1 a} \\
\text { conversion of } \mathbf{1} / \text { yield of } \mathbf{1 a}(\%)\end{array}$ & $\begin{array}{l}\text { Reaction } \mathbf{1} \rightarrow \mathbf{1 b} \\
\text { conversion of } \mathbf{1} / \text { yield of } \mathbf{1 b}(\%)\end{array}$ \\
\hline 1 & 2.0 & 0.2 & $24 / 22$ & $28 / 28$ \\
2 & 5.0 & 0.5 & $49 / 42$ & $55 / 54$ \\
3 & 10.0 & 0.9 & $86 / 67$ & $76 / 76$ \\
4 & 15.0 & 1.4 & $100 / 90$ & $100 / 97$ \\
5 & 20.0 & 1.8 & $100 / 92$ & $100 />99$ \\
\hline
\end{tabular}

Standard conditions were applied. 1, $20 \mathrm{mg} ; 425 \mathrm{~nm} \mathrm{LED} ; \mathrm{N}_{2} ;$ r.t.; $24 \mathrm{~h}$. Other conditions: for phenylation benzene $(2.0 \mathrm{~mL})$ was the solvent; for hydrodeiodination $\mathrm{CsF}(40 \mathrm{mg})$ was essential and $\mathrm{MeCN}$ was the solvent. Conversion and yields were determined by $\mathrm{GC}$ with $n-\mathrm{C}_{14} \mathrm{H}_{30}$ as the internal standard.

Table S4. Effects of added amount of CsF on reaction $\mathbf{1} \rightarrow \mathbf{1 b}$

\begin{tabular}{llll}
\hline Entry & Amount of CsF $(\mathrm{mg})$ & Conversion of $\mathbf{1}(\%)^{\mathrm{b}}$ & Yield of $\mathbf{1 b}(\%)$ \\
\hline 1 & 0 & 36 & 36 \\
2 & 6.5 & 47 & 47 \\
3 & 13 & 85 & 85 \\
4 & 26 & 94 & 94 \\
5 & 40 & 100 & $>99$ \\
\hline
\end{tabular}

Conditions: 1, $20 \mathrm{mg}$; CsF (40 mg), $2 \mathrm{~mL} \mathrm{MeCN,} 425 \mathrm{~nm} \mathrm{LED}$; $\mathrm{N}_{2}$; r.t.; 24 h. Conversion and yields were determined by gas chromatography using $n-\mathrm{C}_{14} \mathrm{H}_{30}$ as the internal standard.
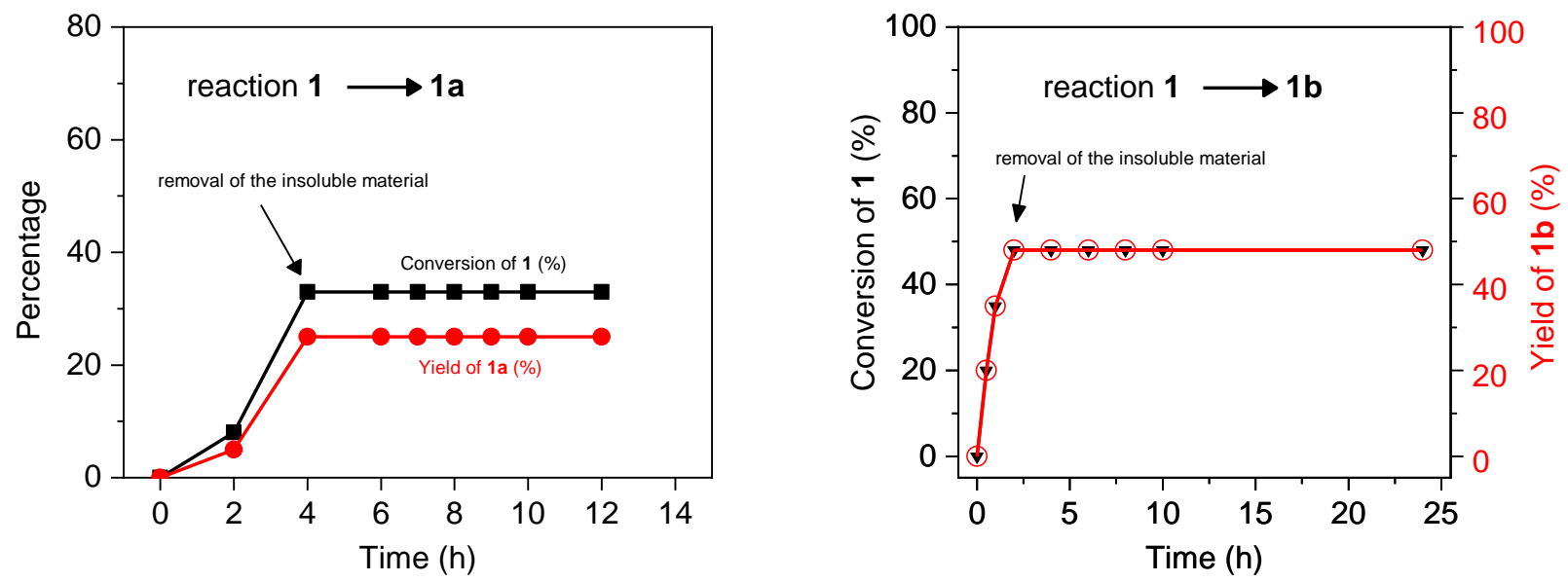

Figure S2. Leaching tests. Standard conditions were applied. 

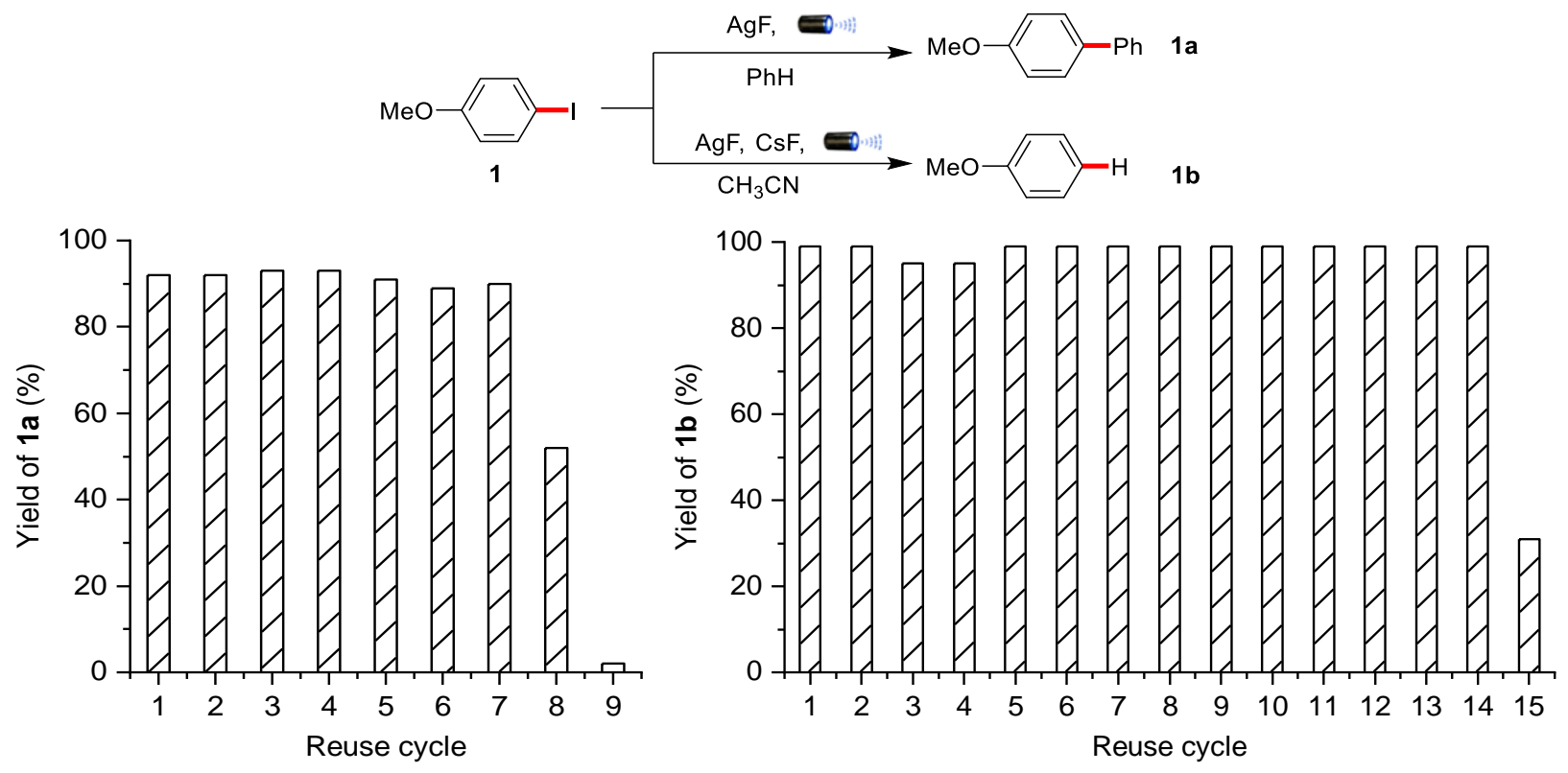

Figure S3. The recycling experiments of the AgF/visible-light system. After each run, the supernatant was carefully withdrawn by a pipette for analysis and afterwards fresh reactants and solvent were added for the next run. For all the experiments, conversion of 1 could reach $100 \%$. The overall TON was calculated as moles of converted 1 divided by moles of AgF. Conditions for $\mathbf{1} \rightarrow \mathbf{1 a}: \mathbf{1}, 20 \mathrm{mg}$ (0.085 mmol); AgF, $20 \mathrm{mg}$; benzene, $2 \mathrm{~mL}$; $425 \mathrm{~nm}$ LED; r.t. Conditions for $\mathbf{1} \rightarrow \mathbf{1 b}$ : 1, $20 \mathrm{mg}$; AgF, $20 \mathrm{mg}$; CsF, $40 \mathrm{mg}$; MeCN, $2.0 \mathrm{~mL} ; 425 \mathrm{~nm} \mathrm{LED}$; $\mathrm{N}_{2} ;$ r.t.; 12 h. TON = 4.1 for the left panel and TON $=7.8$ for the right panel.
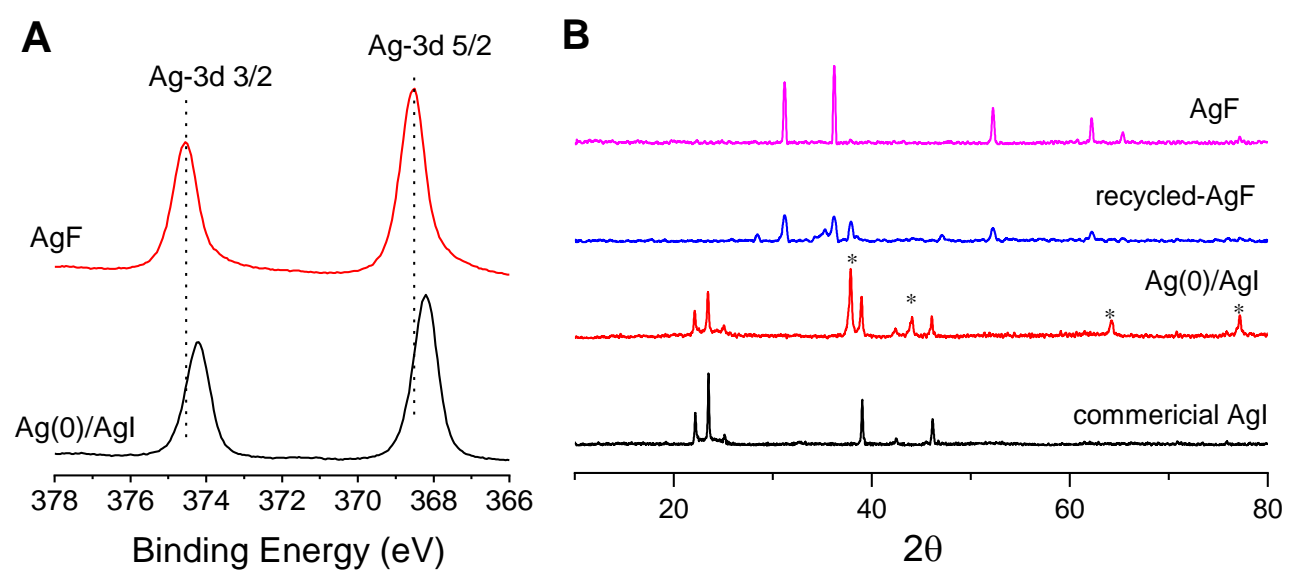

Figure S4. (A) XPS and (B) PXRD data of the various samples. The peaks marked with "** are assigned as $\operatorname{Ag}(0)$. Both XPS and PXRD confirm the existence of elemental $\operatorname{Ag}(0)$ in both recycled-AgF and $\operatorname{Ag}(0) / \operatorname{AgI}$. PXRD suggests $\operatorname{Ag}(0) / \mathrm{AgI}$ does not contain AgF. PXRD also demonstrates that both $\alpha$ and $\beta$ phases of AgI exist in both recycled-AgF and $\mathrm{Ag}(0) / \mathrm{AgI}$. 

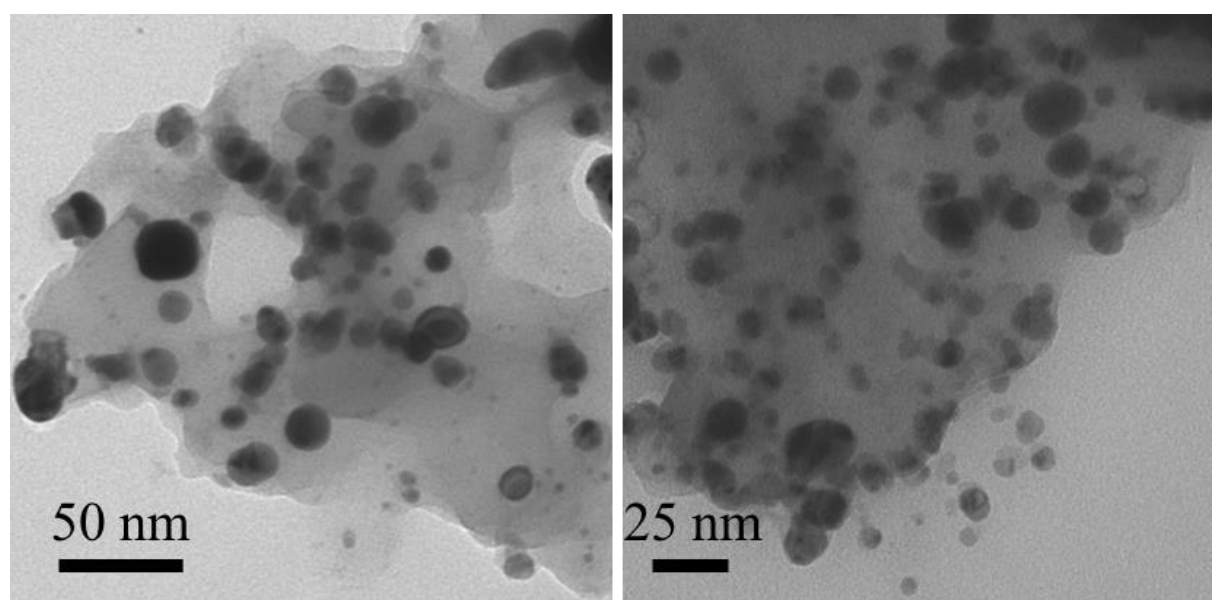

Figure S5. TEM images of $\mathrm{Ag}(0) / \mathrm{AgI}$.

Discussion on the assignment of the $\mathbf{g}=\mathbf{2 . 0 0 3}$ peak. When $E S R$ measurement of $\mathrm{Ag}(0) / \mathrm{AgI}$ was optimized, no additional peak of Ag was observed in wider scan range (2000 - 5000 Gauss) or using higher gain. The line shape did not change as temperature decreased to $-170{ }^{\circ} \mathrm{C}$ (see the figure below). The half width of the $\mathrm{g}=2.003$ peak is ca. 15 gauss, much wider than a normal carbon-centered radical (ca. 2.5 gauss), suggesting this is not a carboncentered radical. When recycled-AgF was soaked in $\mathrm{NaBH}_{4}, \mathrm{HCl}$ or TEMPO solution, the $\mathrm{g}=2.003$ peak remained intact. In addition, the height of the $\mathrm{g}=2.003$ peak decreased sharply when recycled-AgF was ground in an agate mortar (see the figure below). The above evidences unequivocally indicated that the $g=2.003$ peak should not be assigned as $\operatorname{Ag}(\mathrm{I}), \operatorname{Ag}(\mathrm{II})$ or carbon-centered radicals. Rather, it should be assigned as $\operatorname{Ag}(0)$.
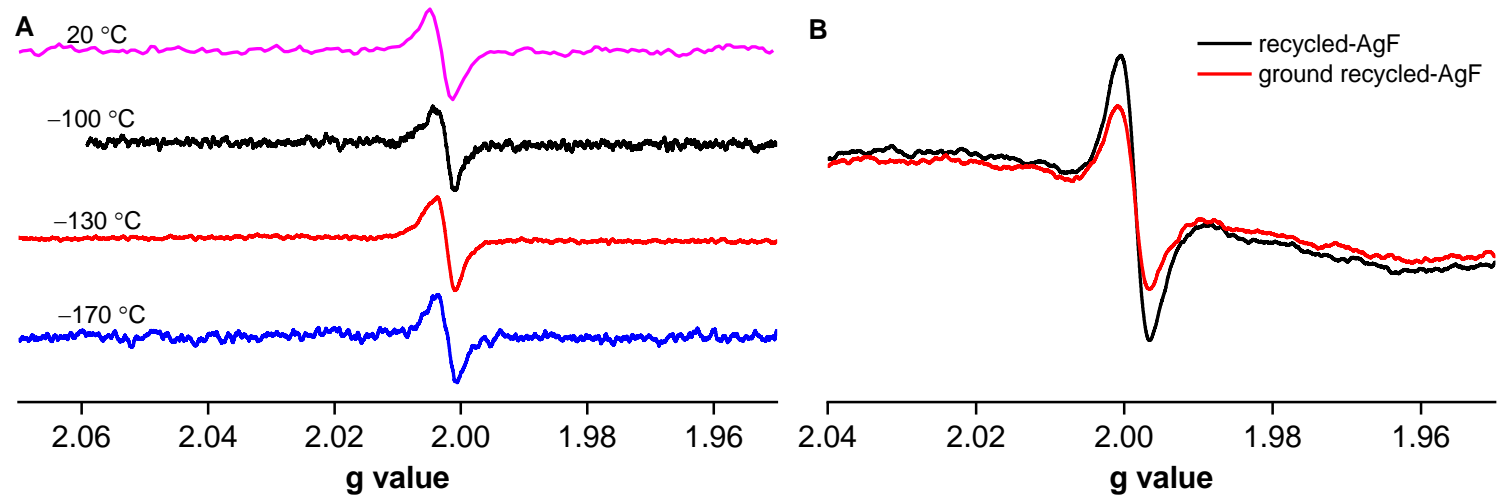

Figure S6. (A) Variable temperature ESR of $\mathrm{Ag}(0) / \mathrm{AgI}$. (B) ESR spectra of recycled-AgF and ground recycled$\mathrm{AgF}$ showing the $\mathrm{g}=2.003$ peak became smaller after grinding.

ESR has been used previously to show that small Ag clusters can be paramagnetic. The peak of $\operatorname{Ag}(0)$ is centered at ca. $\mathrm{g}=2.001 .{ }^{7} \mathrm{An} \mathrm{Ag}_{\mathrm{n}}$ cluster that contains an unpaired electron shows $\mathrm{n}+1$ peaks since the nuclear spin of $\mathrm{Ag}$ is $\mathrm{I}=1 / 2$. For example, the quartet of the Ag@MOF-508 sample $(\mathrm{g}=2.001)$ was assigned as an linear $\mathrm{Ag}_{3}{ }^{0}$ cluster. $^{7}$ 
Ledo-Suarez et al. assigned the sextet $(\mathrm{g}=2.0 ; 1: 1: 1: 1: 1: 1 ; \mathrm{A} \approx 9 \mathrm{mT})$ to an $\mathrm{Ag}_{5}{ }^{0}$ cluster stabilized in a microemulsion. ${ }^{8}$ Cremer et al. assigned a seventet $\left(\mathrm{g}=2.03, \mathrm{~A} \approx 6.75 \mathrm{mT}\right.$ ) as an $\mathrm{Ag}_{6}{ }^{\mathrm{n}+}$ cluster (with $\mathrm{n}=1,3$, or 5 ) formed by reduction of $\mathrm{Ag}^{+}$-exchanged zeolites by $\mathrm{H}_{2}{ }^{9}$

There are indeed a few studies reporting the $\mathrm{g} \approx 2.0$ singlet signal of $\mathrm{Ag}$, which are precisely similar to the current study which is assigned as SAAg. For example, the $\mathrm{Ag}(0)$ species stabilized in a copolymer prepared using microwave, ${ }^{10}$ an Ag-containing BEA zeolite by Popovych et al. ${ }^{11}$ prepared by the "ion exchange - calcination at $773 \mathrm{~K}-$ reduction by $\mathrm{H}_{2}$ " protocol, and an $\mathrm{AgNP} / \mathrm{SiO}_{2}$ sample by Mitrikas et al. ${ }^{12}$ prepared by three steps (first disperse $\mathrm{AgNO}_{3}$ in a silica gel, then calcination in air, and finally calcination in $\mathrm{H}_{2}$ ), as follows:
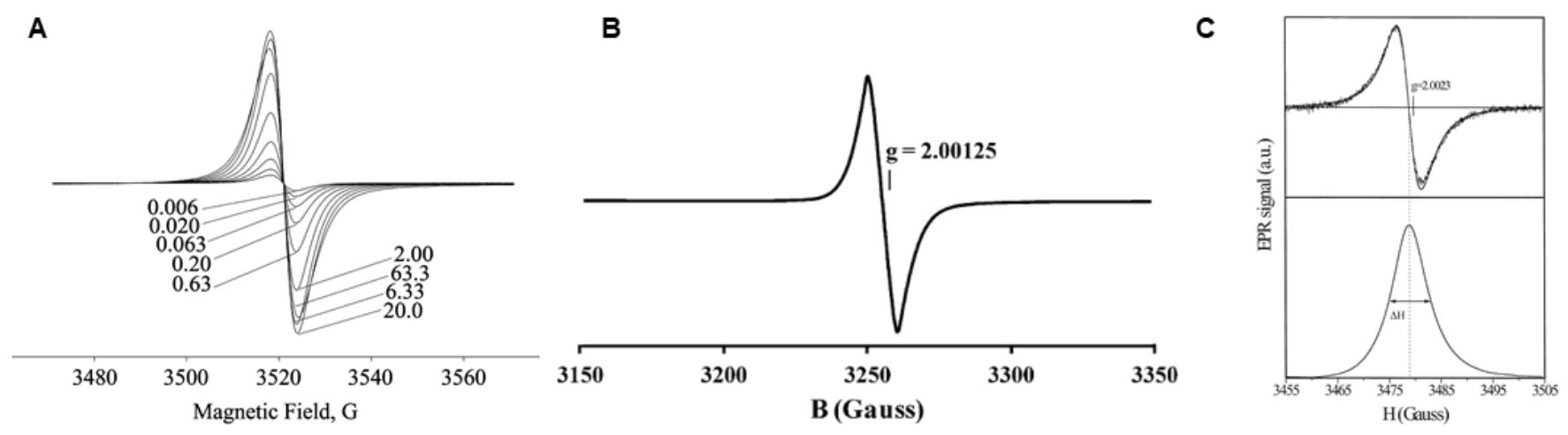

Figure S7. The ESR spectra of Ag species in literature. (A) ESR spectra of a silver-containing nanocomposite of the copolymer VT-AN at various microwave powers $(\mathrm{mW}) .{ }^{10}$ The sample contains $10^{19}-10^{20} \mathrm{spin} / \mathrm{g}$, smaller than $6 \times 10^{16} \mathrm{spin} / \mathrm{g}$ of our $\mathrm{Ag}(0) / \mathrm{AgI}$ sample. (B) ESR spectrum of an Ag-containing zeolite reported by Popovych et al. ${ }^{11}$ (C) ESR spectrum of an $\mathrm{AgNP} / \mathrm{SiO}_{2}$ sample by Mitrikas et al. ${ }^{12}$

Different from the current study, the authors assigned the singlet at $\mathrm{g} \approx 2.00$ as isolated mononuclear $\mathrm{Ag}(\mathrm{I})$ species or AgNPs. ${ }^{10-12}$ However, although the TEM images provided in these articles are usually of low resolution, numerous sub-nanometer particles could still be discernable. In order to check the status of silver in these reports, we synthesized the material following the protocol of ref. 11 (denoted as $\operatorname{Ag}(0) / \mathrm{BEA} ; \beta$-type zeolite with pore size 0.55-0.7 nm purchased from Aladdin, Co). ESR spectra recorded at room temperature showed a $\mathrm{g} \approx 2.00$ peak. When $\mathrm{Ag}(0) / \mathrm{BEA}$ was soaked in $\mathrm{Na}_{2} \mathrm{~S}_{2} \mathrm{O}_{3}, \mathrm{NaBH}_{4}, \mathrm{HCl}$ or TEMPO solution, the $\mathrm{g} \approx 2.00$ peak remained intact (see Figure S8A), indicating the $g \approx 2.00$ peak must be assigned as $\operatorname{Ag}(0) . \operatorname{Ag}(0) / B E A$ was then used for catalyzing the reaction $\mathbf{1} \rightarrow \mathbf{1 a}$ (using the standard conditions) and the conversion (yield) reached 21\% (18\%). For reaction $\mathbf{1} \rightarrow$ $1 \mathrm{~b}$ (using the standard conditions), the conversion and yield reached $54 \%$ and $50 \%$. Hence, $\operatorname{Ag}(0) / \mathrm{BEA}$ is an active photocatalyst. Finally, $\mathrm{Ag}(0) / \mathrm{BEA}$ was soaked in $1.0 \mathrm{M}$ aqueous $\mathrm{Na}_{2} \mathrm{~S}_{2} \mathrm{O}_{3}$ for three times to thoroughly remove excess $\mathrm{Ag}^{+}$(the resultant material is denoted as AgNP/BEA-R) for AC-STEM imaging (see Figure S8). It was found out that numerous SAAg existed in the vicinity of AgNPs. Therefore, the material reported by Popovych et al. ${ }^{11}$ 
contained SAAg which was not characterized in their report, and the $\mathrm{g}=2.00125 \mathrm{ESR}$ peak should be assigned as SAAg according the the current study.

A
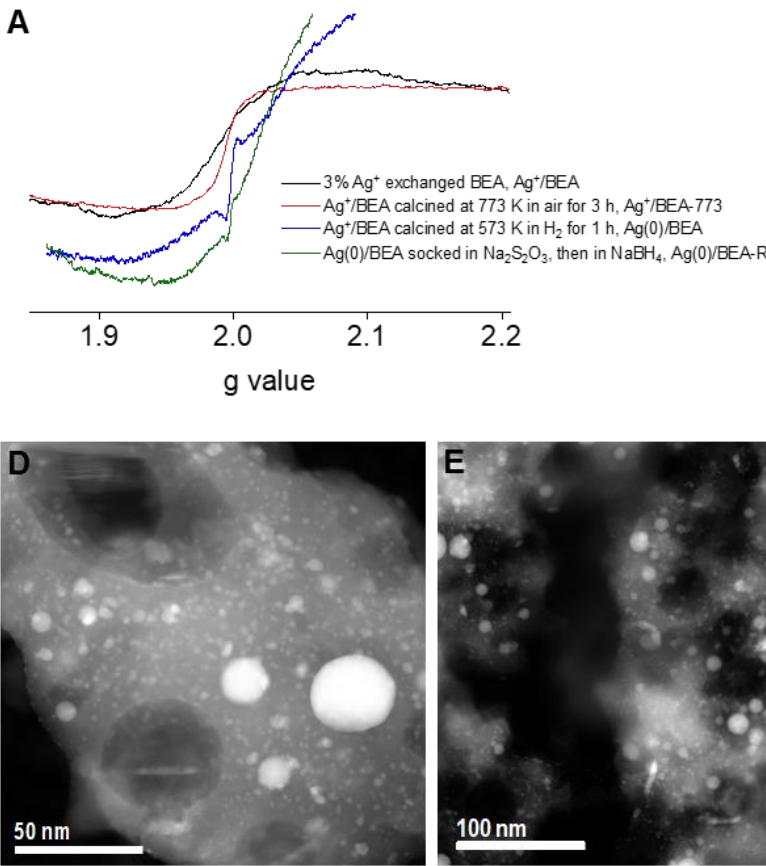

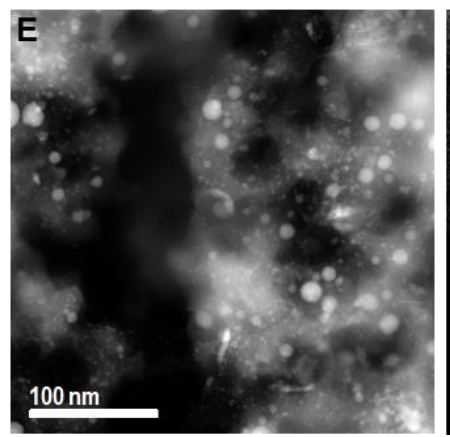

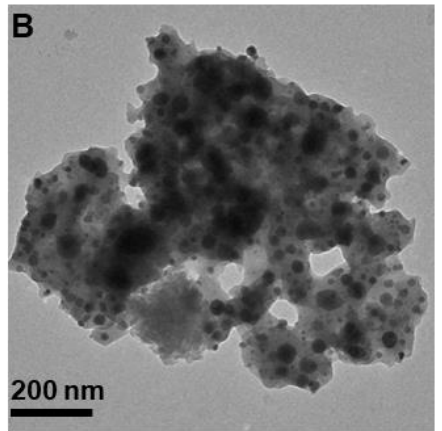
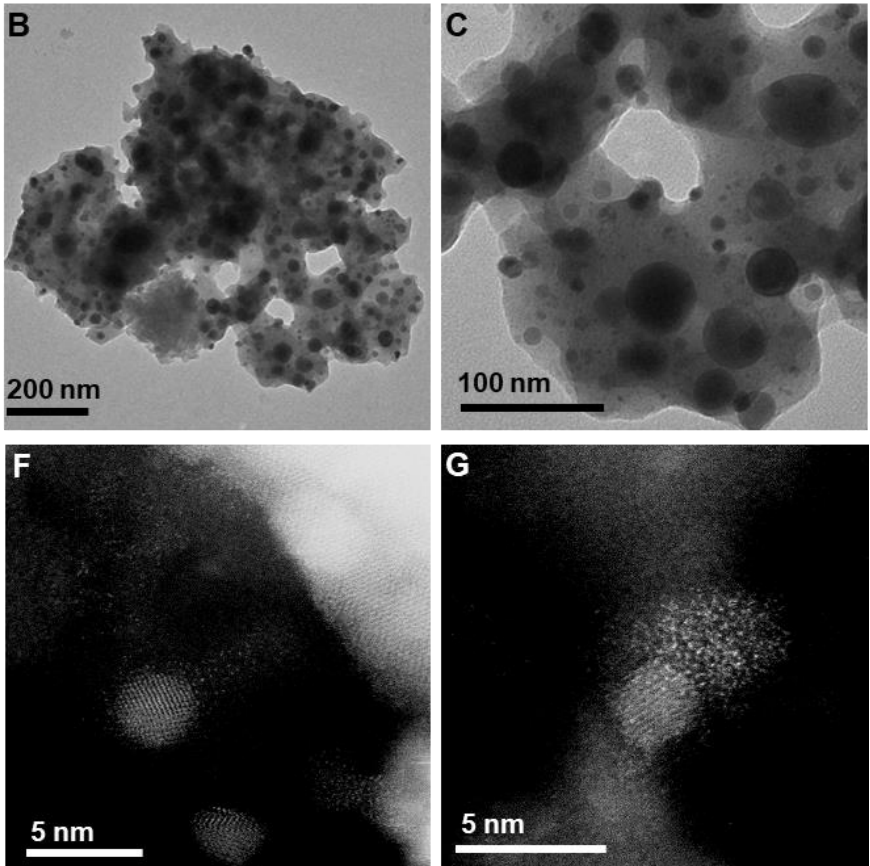

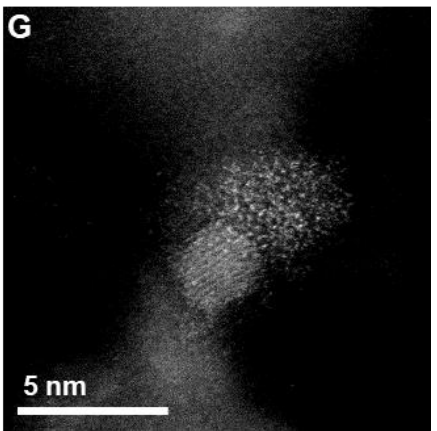

Figure S8. (A) ESR spectra. (B, C) TEM images of $\mathrm{Ag}(0) / \mathrm{BEA}$ prepared following the literature method ${ }^{11}$ showing many AgNPs of $<10 \mathrm{~nm}$. (D, E) dark field HR-TEM and $(\mathbf{F}, \mathbf{G})$ dark field AC-STEM of Ag( $(0) / \mathrm{BEA}-\mathrm{R}$. The dark field HR-TEM images show there are many sub-nanometer $\operatorname{Ag}(0)$ clusters. The AC-STEM images show there are many SAAg in the vicinity of AgNPs.

Then, two SAAg-containing samples which also exhibit the $\mathrm{g}=2.003$ peak, i.e., $\mathrm{Ag}_{1} / \mathrm{SiO}_{2}$ and $\mathrm{Ag}_{1} / \mathrm{GO}$, were prepared by photolysis of frozen aqueous $\mathrm{AgNO}_{3}{ }^{2}$ Because both are phase-pure, the magnetic impurities are not responsible for their ESR peaks (Figure S9). Notably, due to $\mathrm{Ag}-\mathrm{Ag}$ bonding, an $\operatorname{Ag}(0)_{2 \mathrm{n}+1}$ cluster possesses only one unpaired electron, an $\operatorname{Ag}(0)_{2 n}$ cluster should not possess any unpaired electron and as a result is ESR-silent, and a nanosized $\operatorname{Ag}(0)$ particle may possess one unpaired electron but is also ESR-silent due to peak broadening. ${ }^{13}$ Therefore, since in the AC-STEM images of $\mathrm{Ag}_{1} / \mathrm{GO}$ individual $\mathrm{Ag}$ atoms account for the major population among the silver species on the GO substrate (Figures S9-S11), the observed $g=2.003$ peak should be assigned as SAAg. So far as we know it is the first time assigning the $g=2.003$ peak to SAAg in the current study. The reason why SAAg showed a singlet signal was not known and herein we tentatively attribute this to very weak spin-orbital coupling of SAAg. 
A
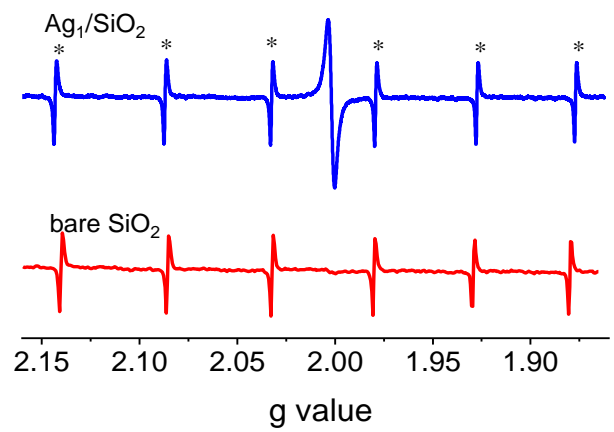

B
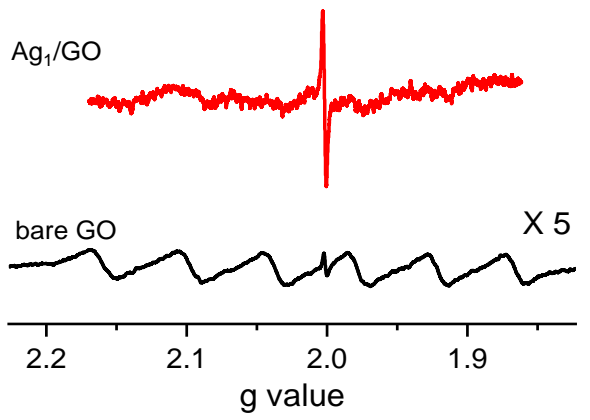

Figure S9. ESR of bare $\mathrm{SiO}_{2}, \mathrm{Ag}_{1} / \mathrm{SiO}_{2}$, bare $\mathrm{GO}$ and $\mathrm{Ag}_{1} / \mathrm{GO}$. The sextet peaks marked with "**" are attributed to the Mn marker of the instrument. The origin of the small $\mathrm{g} \approx 2.0$ peak of bare GO was not known. The waves in the ESR of bare GO are attributed to the unpaired electrons of GO itself. However, due to the much stronger $g=2.003$ peak of SAAg, the native signals of GO were greatly suppressed in the ESR spectrum of $\mathrm{Ag}_{1} / \mathrm{GO}$. The common $\mathrm{g}$ $=2.003$ peak of $\mathrm{Ag}_{1} / \mathrm{GO}$ and $\mathrm{Ag}_{1} / \mathrm{SiO}_{2}$ and the following TEM images indicate the $\mathrm{g}=2.003$ peak should be attributed to SAAg.
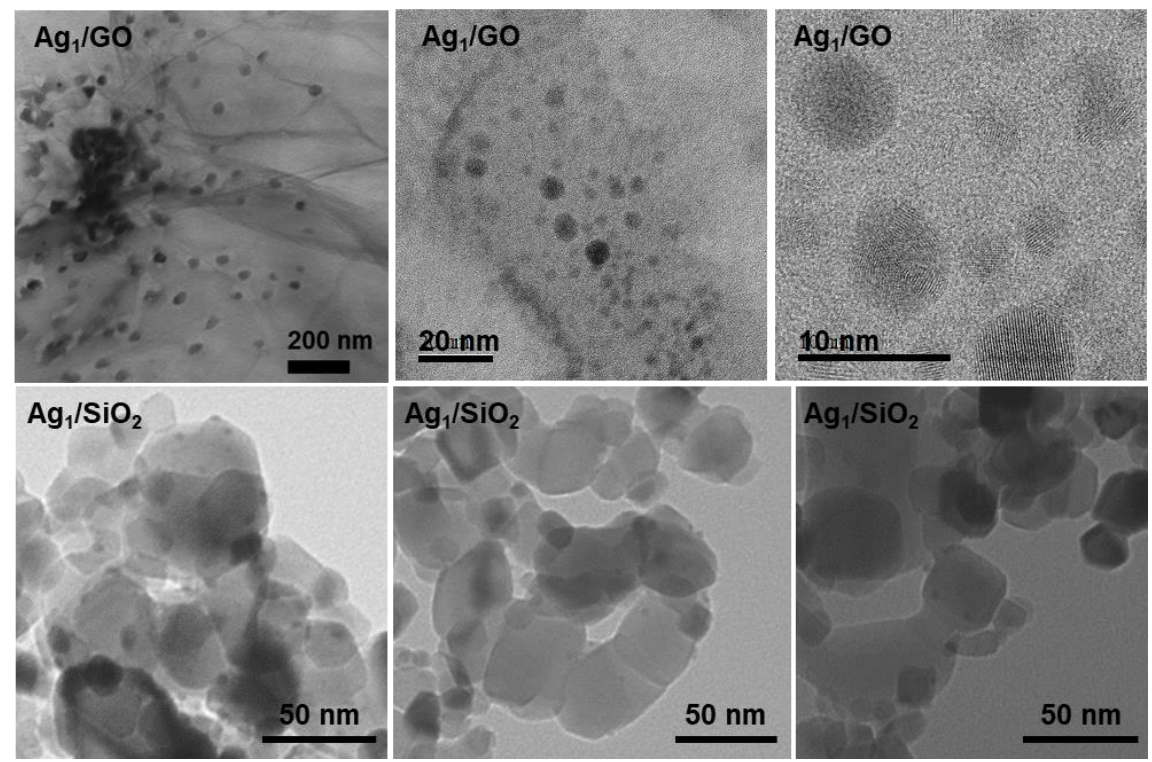

Figure S10. The low-resolution TEM images of $\mathrm{Ag}_{1} / \mathrm{GO}$ and $\mathrm{Ag}_{1} / \mathrm{SiO}_{2}$. The images show that many $\mathrm{Ag}(0)$ nanoparticles are dispersed on the supports. 


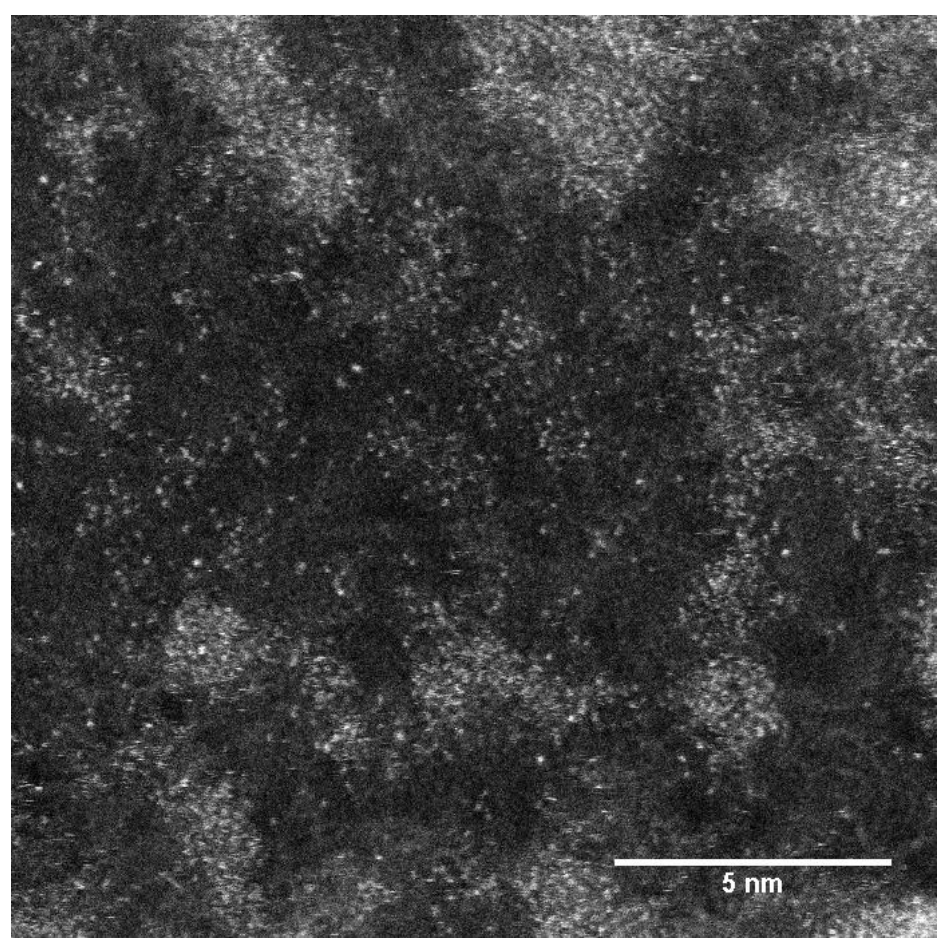

Figure S11. AC-STEM image of $\mathrm{Ag}_{1} / \mathrm{GO}$. $\mathrm{An} \mathrm{Ag}_{2 \mathrm{n}+1}$ cluster (containing $\mathrm{Ag}-\mathrm{Ag}$ bond) possesses only one unpaired electron whereas all the electrons of an $\mathrm{Ag}_{2 n}$ cluster are paired. Although there are many clusters in the $\mathrm{Ag}_{1} / \mathrm{GO}$ sample, there are much more isolated Ag atoms (in number) as evidenced by the AC-STEM image. Since in the ESR measurements peak intensity $(\mathrm{g} \approx 2)$ is proportional to the number concentration of the unpaired electrons, SAAg contributes much more to the ESR intensity than the small $\mathrm{Ag}_{2 \mathrm{n}+1}$ clusters. Therefore, the $\mathrm{g}=2.003$ peak of Figure $\mathrm{S} 7$ should be assigned as SAAg.

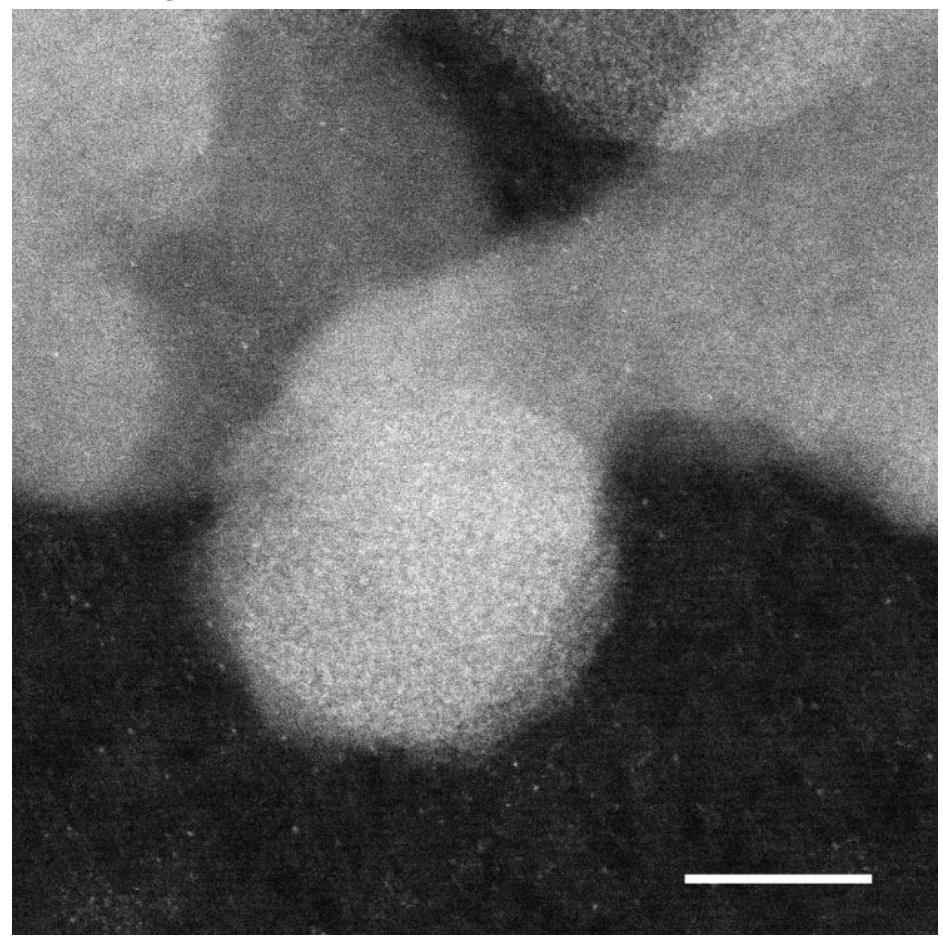

Figure S12. A full AC-STEM image of $\mathrm{Ag}(0) / \mathrm{SiO}_{2}$. Bar $=5 \mathrm{~nm}$. No $\mathrm{Ag}_{2-10}$ sub-nanoclusters are discernable, implying their quantities should be very small. 

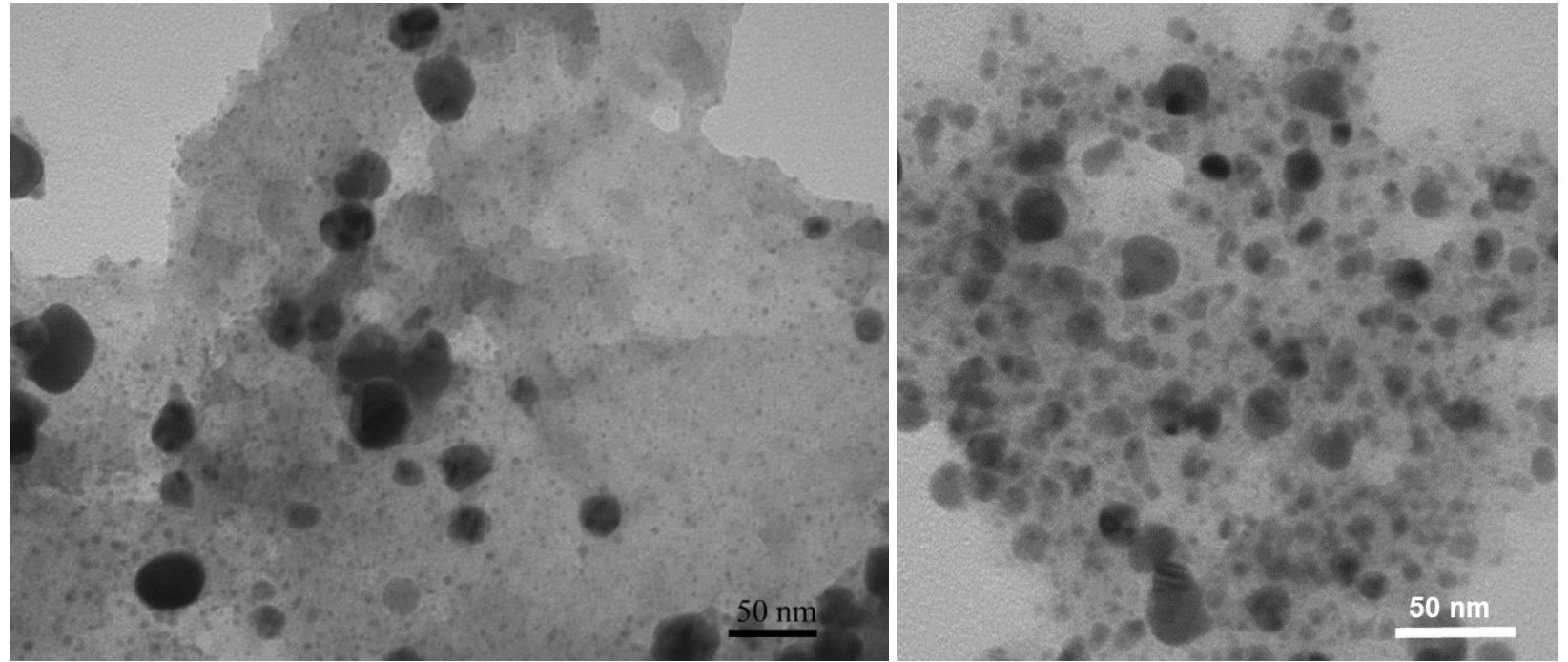

Figure S13. More TEM images of recycled-AgF.
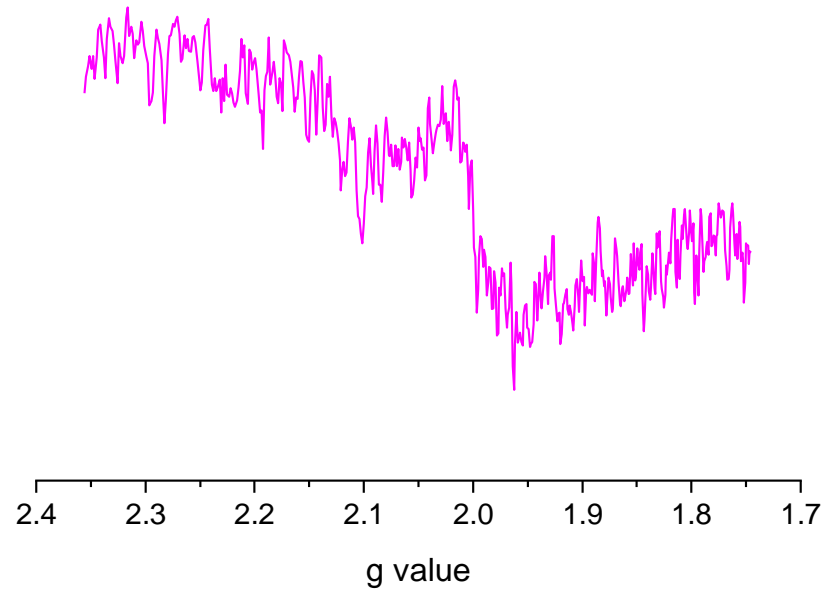

Figure S14. The ESR spectrum of phenylsilver synthesized following the literature protocol. ${ }^{14}$ Hence, phenylsilver was not involved in the present system. 


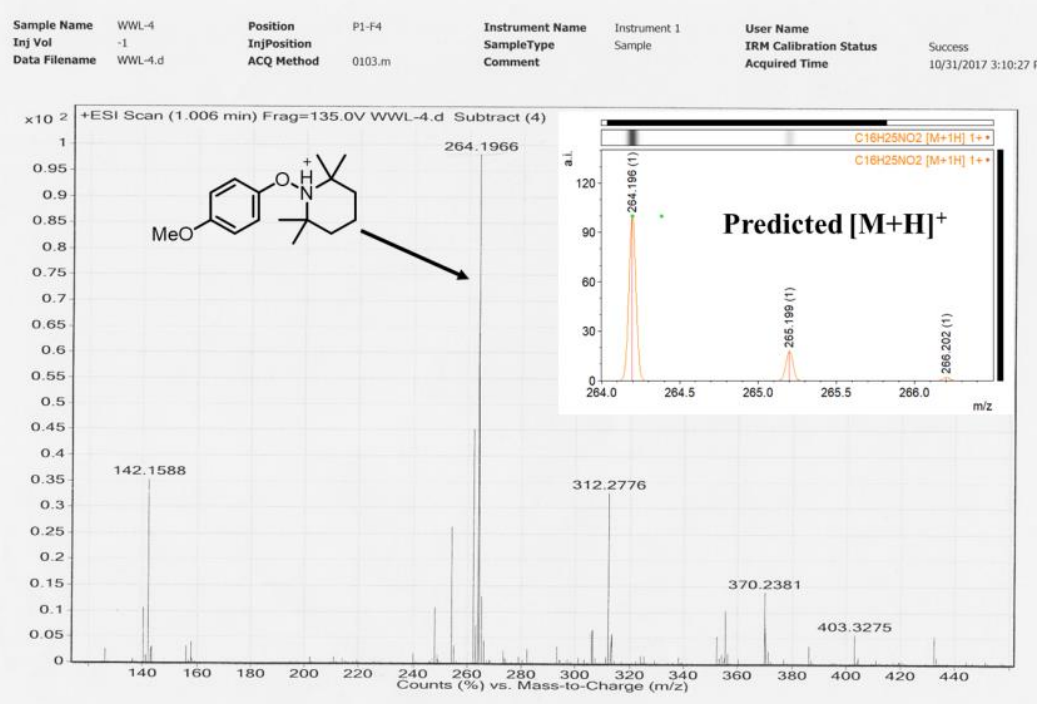

Figure S15. Determination of the PMP-TEMPO adduct by HR-MS for the radical trapping experiment with TEMPO. The reaction was performed following the standard conditions for the phenylation of 1 with 1 eq of added TEMPO.
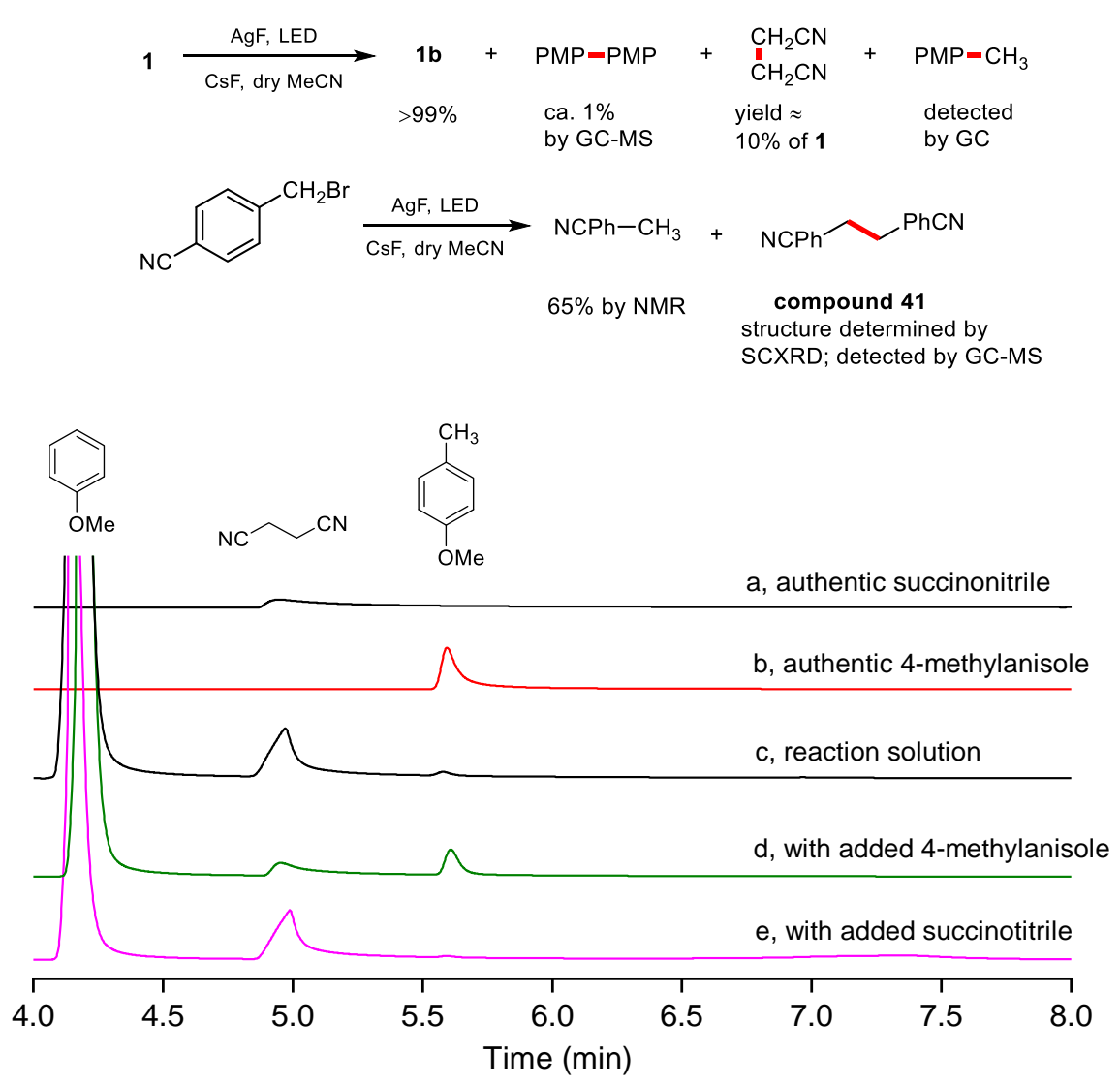

Figure S16. Determination of the byproducts in the hydrodehalogenation reaction. The reaction solution was concentrated for the GC measurements. The data suggest the deiodination of $\mathbf{1}$ by the AgF/visible-light system follows 
a radical chain mechanism. Formation of the byproducts may involve radical chain propagation and radical-radical coupling.
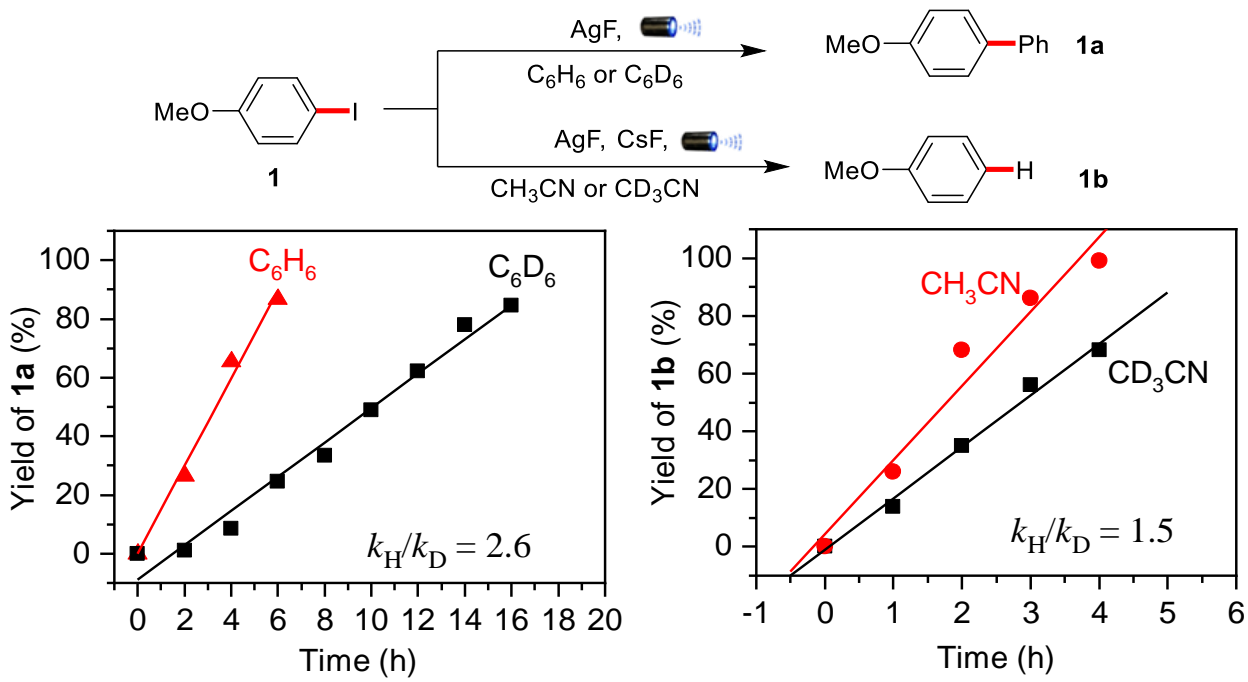

Figure S17. Effects of deuterated solvents on the kinetics of the deiodination of 1 in the presence of AgF. Note that only the linear parts of the kinetic plots are shown here. The pronounced KIEs infer that the conversion of the PMP$\mathrm{I}-\mathrm{Ag}_{1}$ intermediate to the desired products is the rate limiting step. Conditions refer to standard conditions in Tables $\mathrm{S} 1$ and $\mathrm{S} 2$.

\section{Characterization Data of the Products}
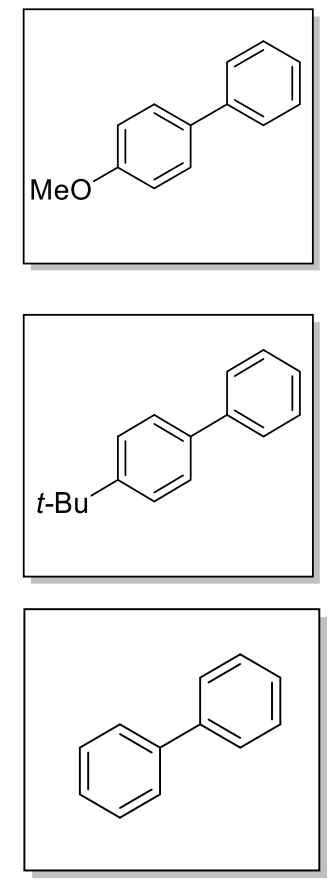

1a, (4-methoxy-1,1'-biphenyl)

The synthesis of $\mathbf{1 a}$ by the AgF/visible-light system was performed following the "standard conditions" for $12 \mathrm{~h}$.

${ }^{1} \mathrm{H}$ NMR $\left(500 \mathrm{MHz}, \mathrm{CDCl}_{3}\right) \delta$ 7.57-7.53 (m, 4H), 7.44-7.41(m, 2H), 7.32-7.31 $(\mathrm{m}, 1 \mathrm{H}), 6.99(\mathrm{~d}, J=10 \mathrm{~Hz}, 2 \mathrm{H}), 3.86(\mathrm{~s}, 3 \mathrm{H}) ;{ }^{13} \mathrm{C} \mathrm{NMR}\left(126 \mathrm{MHz}, \mathrm{CDCl}_{3}\right) \delta$ $158.16,139.87,132.76,127.69,127.06,125.71,125.63,113.17,54.26$.

2a, 4-(tert-butyl)-1,1'-biphenyl

Standard conditions, $12 \mathrm{~h}$.

${ }^{1} \mathrm{H}$ NMR (500 MHz, $\left.\mathrm{CDCl}_{3}\right) \delta$ 7.61-7.30 (m, 9H), $1.36(\mathrm{~s}, 9 \mathrm{H}) ;{ }^{13} \mathrm{C}$ NMR (126 $\left.\mathrm{MHz}, \mathrm{CDCl}_{3}\right) \delta 150.27,141.09,138.34,137.08,128.71,127.60,127.05,127.00$, $126.81,125.73,34.56,31.40,31.17,29.74$.

3a, 1,1'-biphenyl

Standard conditions, $12 \mathrm{~h}$.

${ }^{1} \mathrm{H}$ NMR $\left(500 \mathrm{MHz}, \mathrm{CDCl}_{3}\right) \delta$ 6.61-7.44(m, 8H), 3.27-7.35(m, 2H); ${ }^{13} \mathrm{C} \mathrm{NMR}$ $\left(126 \mathrm{MHz}, \mathrm{CDCl}_{3}\right) \delta 141.26,128.77,127.27,127.19$. 

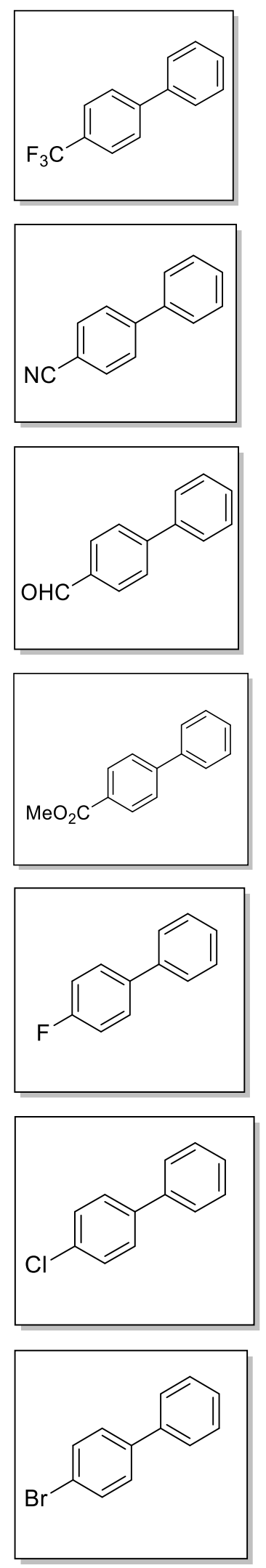

4a, 4-(trifluoromethyl)-1,1'-biphenyl

Standard conditions, $12 \mathrm{~h}$.

${ }^{1} \mathrm{H} \mathrm{NMR}\left(500 \mathrm{MHz}, \mathrm{CDCl}_{3}\right) \delta$ 7.69-7.40 (m, 9H); ${ }^{13} \mathrm{C} \mathrm{NMR}\left(126 \mathrm{MHz}, \mathrm{CDCl}_{3}\right)$ $\delta 144.85,139.79,129.01,128.20,127.44,127.30,125.74,125.71,77.29,77.03$, 76.78 .

5a, [1,1'-biphenyl]-4-carbonitrile

Standard conditions, $12 \mathrm{~h}$.

${ }^{1} \mathrm{H}$ NMR $\left(500 \mathrm{MHz}, \mathrm{CDCl}_{3}\right) \delta$ 7.74-7.68 (m, 4H), 7.60-7.59 (m, 2H), 7.507.41(m,3H); ${ }^{13} \mathrm{C}$ NMR $\left(126 \mathrm{MHz}, \mathrm{CDCl}_{3}\right) \delta 145.70,139.20,132.62,129.14$, $128.68,127.76,127.26,118.97,110.94$

6a, [1,1'-biphenyl]-4-carbaldehyde

Standard conditions, $12 \mathrm{~h}$.

${ }^{1} \mathrm{H}$ NMR $\left(500 \mathrm{MHz}, \mathrm{CDCl}_{3}\right) \delta 10.0(\mathrm{~s}, 1 \mathrm{H}), 7.97-7.95(\mathrm{~m}, 2 \mathrm{H}), 7.77-7.75(\mathrm{~m}$, $2 \mathrm{H}), 7.65-7.64(\mathrm{~m}, 2 \mathrm{H}), 7.50-7.41(\mathrm{~m}, 3 \mathrm{H}) ;{ }^{13} \mathrm{C} \mathrm{NMR}\left(126 \mathrm{MHz}, \mathrm{CDCl}_{3}\right) \delta$ $191.93,147.23,139.75,135.23,130.29,129.04,128.50,127.71,127.39$.

7a, methyl [1,1'-biphenyl]-4-carboxylate

Standard conditions, $12 \mathrm{~h}$.

${ }^{1} \mathrm{H} \mathrm{NMR}\left(500 \mathrm{MHz}, \mathrm{CDCl}_{3}\right) \delta 8.12(\mathrm{~d}, J=8.5 \mathrm{~Hz}, 2 \mathrm{H}), 7.68-7.62(\mathrm{~m}, 4 \mathrm{H}), 7.49-$ $7.38(\mathrm{~m}, 3 \mathrm{H}), 3.95$ (s, 3H); ${ }^{13} \mathrm{C} \mathrm{NMR}\left(126 \mathrm{MHz}, \mathrm{CDCl}_{3}\right) \delta$ 167.02, 145.66, $140.03,130.12,128.94,128.92,128.16,127.30,127.07,52.14$.

8a, 4-fluoro-1,1'-biphenyl

Standard conditions, $12 \mathrm{~h}$.

${ }^{1} \mathrm{H}$ NMR (500 MHz, $\left.\mathrm{CDCl}_{3}\right) \delta$ 7.57-7.51(m, 4H), 7.46-7.35 (m, 5H).

9a, 4-chloro-1,1'-biphenyl

Standard conditions, $12 \mathrm{~h}$.

${ }^{1} \mathrm{H}$ NMR (500 MHz, $\left.\mathrm{CDCl}_{3}\right) \delta$ 7.56-7.54 (m, 4H), 7.45-7.44 (m, 2H), 7.36-7.33 $(\mathrm{m}, 1 \mathrm{H}), 7.15-7.11(\mathrm{~m}, 2 \mathrm{H}) ;{ }^{13} \mathrm{C}$ NMR $\left(126 \mathrm{MHz}, \mathrm{CDCl}_{3}\right) \delta 140.99,137.05$, 129.07, 127.03, 115.42.

10a, 4-bromo-1,1'-biphenyl

Standard conditions, $12 \mathrm{~h}$.

${ }^{1} \mathrm{H}$ NMR (500 MHz, $\left.\mathrm{CDCl}_{3}\right) \delta$ 7.58-7.55 (m, 4H), 7.47-7.43 (m, 4H), 7.38-7.35 $(\mathrm{m}, 1 \mathrm{H}) ;{ }^{3} \mathrm{C} \mathrm{NMR}\left(126 \mathrm{MHz}, \mathrm{CDCl}_{3}\right) \delta 140.15,140.06,131.87,128.91,128.76$, $127.68,126.96,121.57$. 

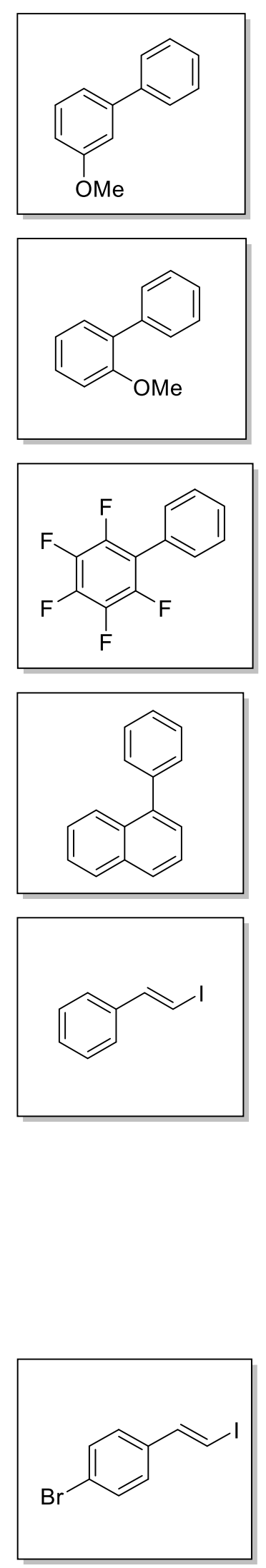

11a, 3-methoxy-1,1'-biphenyl

Standard conditions, $12 \mathrm{~h}$.

${ }^{1} \mathrm{H}$ NMR $\left(500 \mathrm{MHz}, \mathrm{CDCl}_{3}\right) \delta$ 7.56-7.30 (m, 6H), 7.15-7.08 (m, 2H), 6.87-6.85 (m, 1H), $3.83(\mathrm{~s}, 3 \mathrm{H}) ;{ }^{13} \mathrm{C}$ NMR $\left(126 \mathrm{MHz}, \mathrm{CDCl}_{3}\right) \delta 156.66,138.69,130.93$, $129.58,128.64,128.01,126.94,120.86,111.47,55.58$.

12a, 2-methoxy-1,1'-biphenyl

Standard conditions, $12 \mathrm{~h}$.

${ }^{1} \mathrm{H}$ NMR $\left(500 \mathrm{MHz}, \mathrm{CDCl}_{3}\right) \delta$ 7.57-7.33 (m, 7H), 7.07-7.00 (m, 2H), $3.83(\mathrm{~s}$, $3 \mathrm{H}) ;{ }^{13} \mathrm{C}$ NMR $\left(126 \mathrm{MHz}, \mathrm{CDCl}_{3}\right) \delta 156.51,138.66,130.93,130.77,129.58$, $128.64,128.01,126.94,120.86,111.28,55.64$.

13a, 2,3,4,5,6-pentafluoro-1,1'-biphenyl

Standard conditions, $12 \mathrm{~h}$.

${ }^{1} \mathrm{H} \mathrm{NMR}\left(500 \mathrm{MHz}, \mathrm{CDCl}_{3}\right) \delta$ 7.52-7.26 (m, 5H); ${ }^{13} \mathrm{C} \mathrm{NMR}\left(126 \mathrm{MHz}, \mathrm{CDCl}_{3}\right)$ $\delta 130.16,129.32,128.74 ;{ }^{13} \mathrm{~F}$ NMR $\left(\mathrm{CDCl}_{3}\right) \delta-143.21--143.28(\mathrm{~m}, 2 \mathrm{~F})$, 155.54- -155.63(m, 1F), -162.17- -162.28(m, 2F).

14a, 1-phenylnaphthalene

Standard conditions, $12 \mathrm{~h}$.

${ }^{1} \mathrm{H}$ NMR $\left(500 \mathrm{MHz}, \mathrm{CDCl}_{3}\right) \delta$ 7.94-7.88 (m, 3H), 7.56-7.43 (m, 9H); ${ }^{13} \mathrm{C} \mathrm{NMR}$ $\left(126 \mathrm{MHz}, \mathrm{CDCl}_{3}\right) \delta 140.80,140.30,133.83,131.69,130.11,128.29,127.66$, $127.26,126.95,126.06,125.99,125.79,125.41$.

\section{Compound 15, (E)-(2-iodovinyl)benzene}

15 was synthesized following the literature method. ${ }^{15}$ A solution of $\mathrm{CH}_{2} \mathrm{I}_{2}(24.8$ $\mathrm{mmol})$ in $16 \mathrm{~mL}$ of $1: 1(\mathrm{v} / \mathrm{v}) \mathrm{THF} / \mathrm{ether}$ mixture was added dropwise to a solution of NaHMDS ( $2 \mathrm{M}$ in THF, $24.8 \mathrm{~mL}, 49.6 \mathrm{mmol})$ in ca. $30 \mathrm{~min}$ at $-78{ }^{\circ} \mathrm{C}$ in the dark under magnetic stirring. The mixture was stirred for another $20 \mathrm{~min}$, and then a solution of benzyl bromide $(16.6 \mathrm{mmol})$ in THF $(10 \mathrm{~mL})$ was added dropwise in $15 \mathrm{~min}$. The mixture was stirred for $90 \mathrm{~min}$ in the dark and then warmed to room temperature. After $30 \mathrm{~min}$, DBU $(2.5 \mathrm{~mL}, 16.6 \mathrm{mmol})$ was added dropwise and the solution was stirred for $2 \mathrm{~h}$ before ether $(100 \mathrm{~mL})$ was added. The mixture was filtered through celite and then the solvent was removed by rotary evaporation. The residue was purified by flash chromatography to provide the product (yield $=88 \%) .{ }^{1} \mathrm{H}$ NMR $\left(500 \mathrm{MHz}, \mathrm{CDCl}_{3}\right) \delta 7.43(\mathrm{~d}, J=15 \mathrm{~Hz}, 1 \mathrm{H})$, 7.35-7.26 (m, 5H), $6.83(\mathrm{~d}, J=15 \mathrm{~Hz}, 1 \mathrm{H})$.

Compound 16, (E)-1-bromo-4-(2-iodovinyl)benzene

16 was prepared following the same protocol as that for $15 .{ }^{1} \mathrm{H}$ NMR $(500 \mathrm{MHz}$, $\left.\mathrm{CDCl}_{3}\right) \delta 7.37(\mathrm{~d}, J=14.5 \mathrm{~Hz}, 1 \mathrm{H}), 7.27-7.25(\mathrm{~m}, 2 \mathrm{H}), 7.03-6.99(\mathrm{~m}, 2 \mathrm{H})$, $6.75(\mathrm{~d}, J=15 \mathrm{~Hz}, 1 \mathrm{H}) ;{ }^{13} \mathrm{C} \mathrm{NMR}\left(126 \mathrm{MHz}, \mathrm{CDCl}_{3}\right) \delta 163.67,161.69,143.72$, $134.01,133.98,127.65,127.58,115.80,115.63,76.04$. 

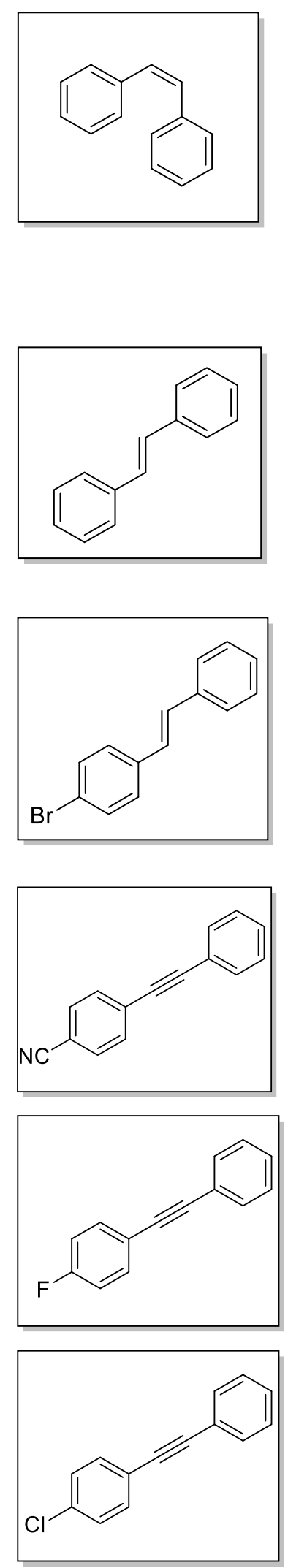

15a, (Z)-1,2-diphenylethene

Standard conditions, $24 \mathrm{~h}$.

The title compound was synthesized from 15 and benzene using the AgF/visiblelight system. Although the substrate (15) was purely Z-isomer, arylation using the current protocol yielded a mixture of $Z$ - and $E$ - isomers, consistent with a radical mechanism. The $Z$ - and $E$ - isomers were isolated using flash chromatography. ${ }^{1} \mathrm{H} \mathrm{NMR}\left(500 \mathrm{MHz}, \mathrm{CDCl}_{3}\right) \delta 7.25-7.14(\mathrm{~m}, 10 \mathrm{H}), 6.58-6.57(\mathrm{~m}, 2 \mathrm{H}) ;{ }^{13} \mathrm{C}$ NMR $\left(126 \mathrm{MHz}, \mathrm{CDCl}_{3}\right) \delta 137.37,130.38,129.20,129.00,128.83,128.75$, $128.57,128.46,128.33,128.13,127.37,127.21,126.93,126.64$.

15a, (E)-1,2-diphenylethene

Standard conditions, $24 \mathrm{~h}$.

The title compound was synthesized from 15 and benzene using the $\mathrm{AgF} / \mathrm{visible-}$ light system. The Z- and E- isomers were isolated using flash chromatography. ${ }^{1} \mathrm{H}$ NMR $\left(500 \mathrm{MHz}, \mathrm{CDCl}_{3}\right) \delta$ 7.53-7.52 (m, 4H), 7.38-7.35 (m, 4H), 7.28-7.24 $(\mathrm{m}, 2 \mathrm{H}), 7.11(\mathrm{~s}, 2 \mathrm{H}) ;{ }^{13} \mathrm{C} \mathrm{NMR}\left(126 \mathrm{MHz}, \mathrm{CDCl}_{3}\right) \delta 137.36,128.73,128.69$, $127.63,126.53$.

16a, a mixture of $Z$ - and $E$ - 1-bromo-4-styrylbenzene

Standard conditions, $24 \mathrm{~h}$.

The $Z$ - and $E$ - isomers could not be separated using flash chromatography. ${ }^{1} \mathrm{H}$ $\operatorname{NMR}\left(500 \mathrm{MHz}, \mathrm{CDCl}_{3}\right) \delta$ 7.52-7.47 (m, 4H), 7.39-7.35 (m, 4H), 7.30-7.26 (m, $1 \mathrm{H}), 7.12-7.02\left(\mathrm{dd}, 2 \mathrm{H}, J_{l}=12.8 \mathrm{~Hz}, J_{2}=33 \mathrm{~Hz}\right) ;{ }^{13} \mathrm{C} \mathrm{NMR}\left(126 \mathrm{MHz}, \mathrm{CDCl}_{3}\right)$ $\delta 136.97,136.30,131.80,129.45,128.76,127.99,127.92,127.42,126.58$, 121.33 .

17a, 4-(phenylethynyl)benzonitrile

Standard conditions, $12 \mathrm{~h}$.

${ }^{1} \mathrm{H}$ NMR (500 MHz, $\left.\mathrm{CDCl}_{3}\right) \delta$ 7.64-7.50 (m, 6H), 7.39-7.38 (m, 3H); ${ }^{13} \mathrm{C}$ NMR $\left(126 \mathrm{MHz}, \mathrm{CDCl}_{3}\right) \delta 132.90,132.09,132.07,131.97,131.81,129.15,128.53$, $128.27,122.24,118.55,111.50,93.80,87.74$.

18a, 1-fluoro-4-(phenylethynyl)benzene

Standard conditions, $12 \mathrm{~h}$.

${ }^{1} \mathrm{H}$ NMR $\left(500 \mathrm{MHz}, \mathrm{CDCl}_{3}\right) \delta$ 7.53-7.50 (m, 4H), 7.35-7.34 (m, 3H), 7.07-7.03 $(\mathrm{m}, 2 \mathrm{H}) ;{ }^{13} \mathrm{C} \mathrm{NMR}\left(126 \mathrm{MHz}, \mathrm{CDCl}_{3}\right) \delta 161.53,133.52,133.46,131.57,128.39$, $128.34,123.11,119.41,115.74,115.56,89.04,88.29$.

19a, 1-chloro--4-(phenylethynyl)benzene

Standard conditions, $12 \mathrm{~h}$.

${ }^{1} \mathrm{H} \mathrm{NMR}\left(500 \mathrm{MHz}, \mathrm{CDCl}_{3}\right) \delta$ 7.54-7.52 (m, 2H), 7.47-7.45 (m, 2H), 7.37-7.26 $(\mathrm{m}, 5 \mathrm{H})$. 

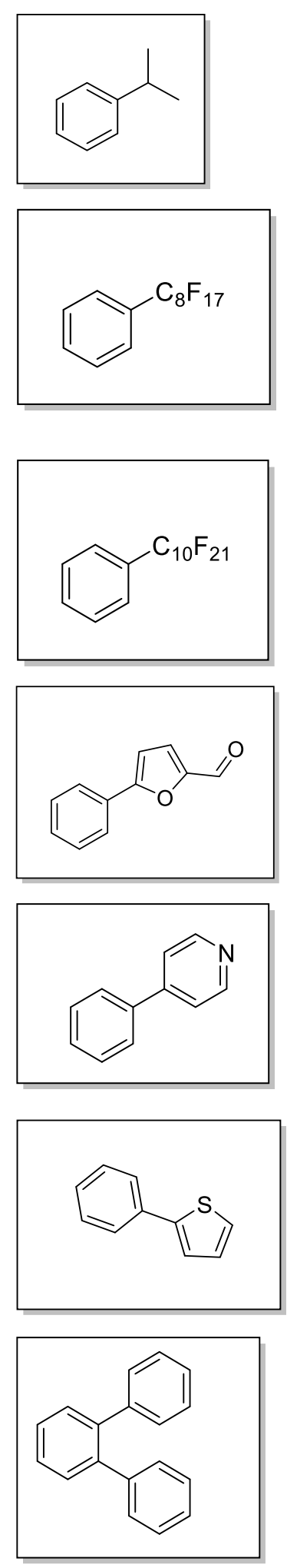

20a, isopropylbenzene

The authentic sample of $\mathbf{2 0 a}$ is commercially available. Hence the yield was determined by GC-FID.

Standard conditions, $48 \mathrm{~h}$.

21a, (perfluorooctyl)benzene

Standard conditions, $48 \mathrm{~h}$.

${ }^{1} \mathrm{H}$ NMR $\left(500 \mathrm{MHz}, \mathrm{CDCl}_{3}\right) \delta$ 7.60-7.56 (m, 3H), 7.52-7.49 (m, 2H); ${ }^{13} \mathrm{C}$ NMR $\left(126 \mathrm{MHz}, \mathrm{CDCl}_{3}\right) \delta 131.89,129.20,129.01,128.82,128.58,126.86,126.80$, $126.75 ;{ }^{19} \mathrm{~F} \mathrm{NMR}\left(470 \mathrm{MHz}, \mathrm{CDCl}_{3}\right) \delta-80.88(\mathrm{t}, 3 \mathrm{~F}),-110.89(\mathrm{t}, 2 \mathrm{~F}),-121.31$ - $122.79(\mathrm{~m}, 10 \mathrm{~F}),-126.21$ (s, 2F).

22a, (perfluorodecyl)benzene

Standard conditions, $48 \mathrm{~h}$.

${ }^{1} \mathrm{H}$ NMR (500 MHz, $\left.\mathrm{CDCl}_{3}\right) \delta$ 7.61-7.49 (m, 5H); ${ }^{19} \mathrm{~F} \mathrm{NMR}\left(470 \mathrm{MHz}, \mathrm{CDCl}_{3}\right)$ $\delta-80.79(\mathrm{t}, 3 \mathrm{~F}),-110.81(\mathrm{t}, 2 \mathrm{~F}),-121.26--122.74(\mathrm{~m}, 14 \mathrm{~F}),-126.10(\mathrm{~s}, 2 \mathrm{~F})$.

23a, 5-phenylfuran-2-carbaldehyde

Standard conditions, $24 \mathrm{~h}$.

${ }^{1} \mathrm{H}$ NMR (500 MHz, $\left.\mathrm{CDCl}_{3}\right) \delta 9.65(\mathrm{~s}, 1 \mathrm{H})$, 7.83-7.81 (m, $\left.2 \mathrm{H}\right)$, 7.45-7.37 (m, $3 \mathrm{H}), 7.31(\mathrm{~d}, J=3.5 \mathrm{~Hz}, 1 \mathrm{H}), 7.31-6.83(\mathrm{~d}, J=3.5 \mathrm{~Hz}, 1 \mathrm{H}) .{ }^{13} \mathrm{C} \mathrm{NMR}(126 \mathrm{MHz}$, $\left.\mathrm{CDCl}_{3}\right) \delta 177.25,159.60,152.21,129.71,129.01,125.32,107.70$.

24a, 4-phenylpyridine

Standard conditions, $24 \mathrm{~h}$.

${ }^{1} \mathrm{H}$ NMR (500 MHz, $\left.\mathrm{CDCl}_{3}\right) \delta 8.67-8.65(\mathrm{~m}, 2 \mathrm{H}), 7.65(\mathrm{~m}, 2 \mathrm{H}), 7.52-7.43(\mathrm{~m}$, $4 \mathrm{H}), 7.26(\mathrm{~m}, 1 \mathrm{H}) ;{ }^{13} \mathrm{C} \mathrm{NMR}\left(126 \mathrm{MHz}, \mathrm{CDCl}_{3}\right) \delta 150.29,148.36,138.19$, $129.13,129.07,127.02,121.66$.

25a, 2-phenylthiophene

Standard conditions, $48 \mathrm{~h}$.

${ }^{1} \mathrm{H}$ NMR $\left(500 \mathrm{MHz}, \mathrm{CDCl}_{3}\right) \delta$ 7.62-7.60 (m, 2H), 7.47-7.46 (m, 1H); 7.42-7.39 $(\mathrm{m}, 4 \mathrm{H}) ; 7.32-7.29(\mathrm{~m}, 1 \mathrm{H}){ }^{13} \mathrm{C} \mathrm{NMR}\left(126 \mathrm{MHz}, \mathrm{CDCl}_{3}\right) \delta 142.36,135.98$, $128.82,127.12,126.48,126.37,126.21,120.29$.

26a, 1,1' 2',1"-terphenyl

Standard conditions, $48 \mathrm{~h}$.

${ }^{1} \mathrm{H}$ NMR $\left(500 \mathrm{MHz}, \mathrm{CDCl}_{3}\right) \delta$ 7.45-7.41 (m, 4H), 7.24-7.14 (m, 10H); ${ }^{13} \mathrm{C}$ NMR $\left(126 \mathrm{MHz}, \mathrm{CDCl}_{3}\right) \delta 141.54,140.60,130.61,129.91,127.86,127.48,126.45$. 

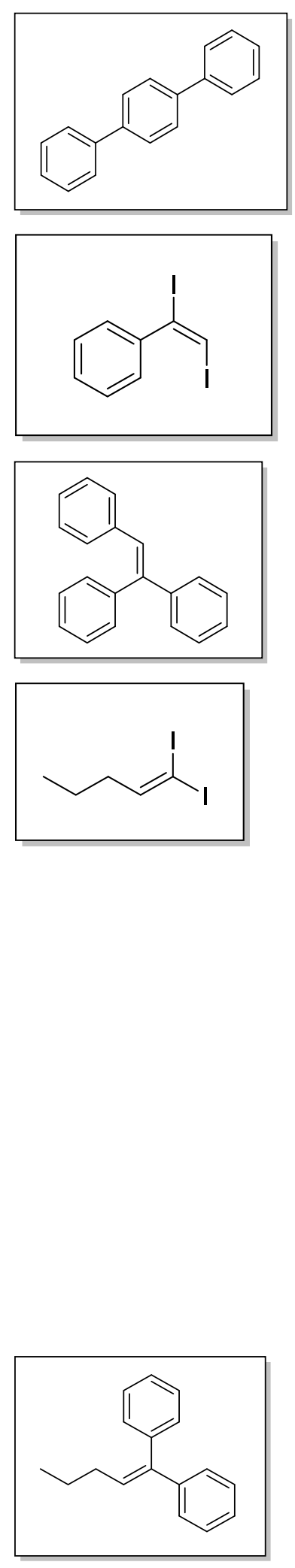

27a, 1,1':4',1"-terphenyl

Standard conditions, $48 \mathrm{~h}$.

${ }^{1} \mathrm{H}$ NMR $\left(500 \mathrm{MHz}, \mathrm{CDCl}_{3}\right) \delta$ 7.69-7.64 (m, 8H), 7.48-7.45 (m, 4H), 7.38-7.35 $(\mathrm{m}, 2 \mathrm{H}) ;{ }^{13} \mathrm{C} \mathrm{NMR}\left(126 \mathrm{MHz}, \mathrm{CDCl}_{3}\right) \delta 140.71,140.13,128.82,127.50,127.49$, 127.34, 127.06, 127.05, 127.05.

compound 28, E-(1,2-diiodovinyl)benzene

Synthesis. Ethynylbenzene ( $1 \mathrm{eq})$ and $\mathrm{I}_{2}(1.05 \mathrm{eq})$ were dissolved in methanol and stirred for $5 \mathrm{~h}$ at room temperature. The product was obtained as white solid after purification. ${ }^{1} \mathrm{H}$ NMR $\left(500 \mathrm{MHz}, \mathrm{CDCl}_{3}\right) \delta 7.39-7.26(6 \mathrm{H}, \mathrm{m}) ;{ }^{13} \mathrm{C} \mathrm{NMR}$ $\left(126 \mathrm{MHz}, \mathrm{CDCl}_{3}\right) \delta 143.11,128.99,128.53,128.45,96.20,80.82$.

28a, ethene-1,1,2-triyltribenzene

Standard conditions, $48 \mathrm{~h}$.

${ }^{1} \mathrm{H} \mathrm{NMR}\left(500 \mathrm{MHz}, \mathrm{CDCl}_{3}\right) \delta$ 7.31-6.96 $(16 \mathrm{H}, \mathrm{m}) ;{ }^{13} \mathrm{C} \mathrm{NMR}\left(126 \mathrm{MHz}, \mathrm{CDCl}_{3}\right)$ $\delta 143.51,142.67,140.44,137.46,130.47,129.63,128.71,128.28,128.24$, $128.04,127.69,127.58,127.48,126.82$.

compound 29, 1,1-diiodopent-1-ene

29 was synthesized following the literature protocol. ${ }^{16}$ First, iodomethyltriphenylphosphonium iodide $\left(\mathrm{Ph}_{3} \mathrm{PCH}_{2} \mathrm{I}\right)^{+} \mathrm{I}^{-}$was synthesized. To a suspension of triphenyl phosphine $(12 \mathrm{~g}, 0.045 \mathrm{~mol})$ in $40 \mathrm{~mL}$ toluene was added diiodomethane $(4.92 \mathrm{~mL}, 1.35 \mathrm{eq})$. The reaction mixture was stirred at $80{ }^{\circ} \mathrm{C}$ for $48 \mathrm{~h}$. The precipitate was then isolated by filtration, washed with toluene and dried in vacuo to afford $\left(\mathrm{Ph}_{3} \mathrm{PCH}_{2} \mathrm{I}\right)^{+} \mathrm{I}^{-}$as a white solid (yield $=91 \%$ ). Next, to a suspension of $\left(\mathrm{Ph}_{3} \mathrm{PCH}_{2} \mathrm{I}\right)^{+} \mathrm{I}^{-}(7 \mathrm{~g}, 1 \mathrm{eq})$ in THF $(10 \mathrm{~mL})$ was added NaHMDS $(2 \mathrm{M}$ in THF, $12.5 \mathrm{~mL}, 1.0 \mathrm{eq}$ ) dropwise. The mixture was stirred at r.t. for $30 \mathrm{~min}$. The resultant red solution was cooled to $-78{ }^{\circ} \mathrm{C}$ in prior to the addition of HMPA $(12.5 \mathrm{~mL}, 5 \mathrm{eq})$ followed by a solution of the $n$-butanol $(1.48 \mathrm{~g}, 1 \mathrm{eq})$ in THF $(10 \mathrm{~mL})$. The reaction mixture was stirred for another $3 \mathrm{~h}$ at $-78{ }^{\circ} \mathrm{C}$ and then quenched with sat. aq. $\mathrm{NaHCO}_{3}(50 \mathrm{~mL})$, diluted with diethyl ether $(2 \times 50 \mathrm{~mL})$, and filtered. The biphasic filtrate was separated, the organic phase was dried $\left(\mathrm{MgSO}_{4}\right)$, filtered and concentrated in vacuo. Finally, the crude product was purified by silica gel chromatography.

${ }^{1} \mathrm{H}$ NMR $\left(500 \mathrm{MHz}, \mathrm{CDCl}_{3}\right) \delta 6.94(\mathrm{t}, J=7 \mathrm{~Hz}, 1 \mathrm{H}), 1.90(\mathrm{q}, J=7 \mathrm{~Hz}, 2 \mathrm{H}), 1.46$ $(\operatorname{sext}, J=5 \mathrm{~Hz}, 2 \mathrm{H}), 0.94(\mathrm{t}, J=7.5 \mathrm{~Hz}, 3 \mathrm{H}) ;{ }^{13} \mathrm{C} \mathrm{NMR}\left(126 \mathrm{MHz}, \mathrm{CDCl}_{3}\right) \delta$ 153.23, 41.55, 29.73, 20.78, 13.63 .

29a, pent-1-ene-1,1-diyldibenzene

Standard conditions, $48 \mathrm{~h}$.

${ }^{1} \mathrm{H}$ NMR $\left(500 \mathrm{MHz}, \mathrm{CDCl}_{3}\right) \delta$ 7.38-7.17 (m, 10H), $6.09(\mathrm{t}, J=7 \mathrm{~Hz}, 1 \mathrm{H}), 2.11-$ $2.07(\mathrm{~m}, 2 \mathrm{H}), 1.48-1.44(\mathrm{~m}, 2 \mathrm{H}), 0.90(\mathrm{t}, J=7.5 \mathrm{~Hz}, 3 \mathrm{H})$ 

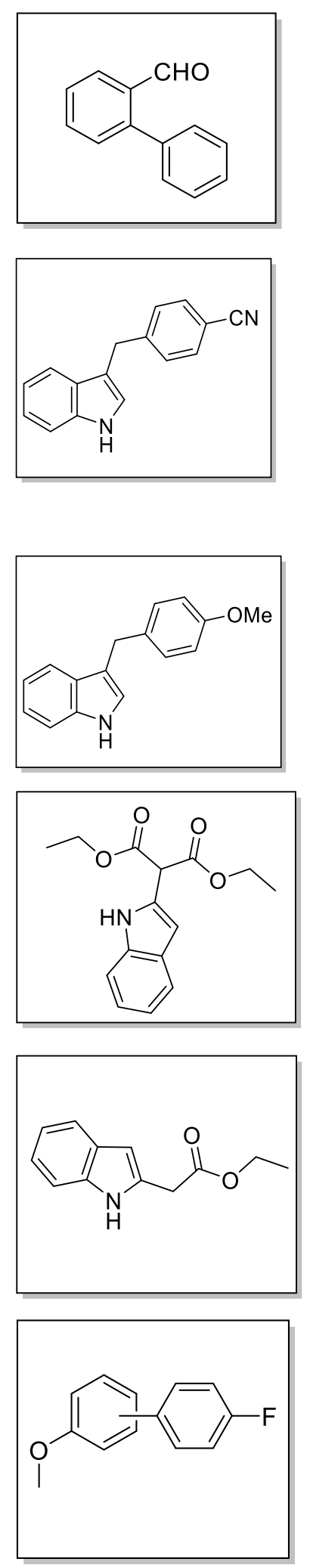

30a, [1,1'-biphenyl]-2-carbaldehyde

Standard conditions, $24 \mathrm{~h}$.

${ }^{1} \mathrm{H} \mathrm{NMR}\left(500 \mathrm{MHz}, \mathrm{CDCl}_{3}\right) \delta 9.99(\mathrm{~s}, 1 \mathrm{H}), 8.04\left(\mathrm{dd}, J_{l}=1 \mathrm{~Hz}, J_{2}=8 \mathrm{~Hz}, 1 \mathrm{H}\right)$, 7.54-7.38 (m, 8H); ${ }^{13} \mathrm{C}$ NMR $\left(126 \mathrm{MHz}, \mathrm{CDCl}_{3}\right) \delta 192.47,145.99,137.78$, $134.70,133.75,133.56,130.79,130.11,129.10,128.69,128.44,128.13,127.79$, 127.59 .

31a, 4-((1H-indol-3-yl)methyl)benzonitrile

The reaction was performed using 4-(bromomethyl)benzonitrile $(0.1 \mathrm{mmol}, 1$ eq), $1 \mathrm{H}$-indole $(0.5 \mathrm{mmol}, 5 \mathrm{eq})$ and $\mathrm{AgF}(0.15 \mathrm{mmol})$ under visible light irradiation. $2 \mathrm{~mL}$ ethanol was the solvent. Reaction time $=6 \mathrm{~h} .{ }^{1} \mathrm{H} \mathrm{NMR}(500 \mathrm{MHz}$, $\left.\mathrm{CDCl}_{3}\right) \delta 8.06(\mathrm{~s}, 1 \mathrm{H}), 7.56(\mathrm{~d}, J=8.5 \mathrm{~Hz}, 2 \mathrm{H}), 7.43-7.36(\mathrm{~m}, 4 \mathrm{H}), 7.23-7.20(\mathrm{~m}$, 1H), 7.11-7.08 (m, 1H), 6.98-6.97 (m, 1H), 4.18 (s, 2H); ${ }^{13} \mathrm{C}$ NMR (126 MHz, $\left.\mathrm{CDCl}_{3}\right) \delta 147.02,136.48,132.51,132.21,129.55,129.38,127.11,122.61$, $122.39,119.68,119.18,118.87,113.96,111.30,109.78,31.80$.

32a, 3-(4-methoxybenzyl)-1H-indole

The protocol is analogous to that for 31a. Reaction time $=6 \mathrm{~h} .{ }^{1} \mathrm{H}$ NMR $(500$ $\left.\mathrm{MHz}, \mathrm{CDCl}_{3}\right) \delta 7.92(\mathrm{~s}, 1 \mathrm{H})$, 7.54-7.53 (m, $\left.1 \mathrm{H}\right)$, 7.37-7.35 (m, 1H), 7.23-7.08 $(\mathrm{m}, 4 \mathrm{H}), 6.90-6.83(\mathrm{~m}, 3 \mathrm{H}), 4.08(\mathrm{~s}, 2 \mathrm{H}), 3.80(\mathrm{~s}, 3 \mathrm{H}) ;{ }^{13} \mathrm{C}$ NMR $(126 \mathrm{MHz}$, $\left.\mathrm{CDCl}_{3}\right) \delta 157.83,136.50,133.33,129.79,129.61,127.45,122.22,122.04$, 119.34, 119.20, 116.32, 113.76, 111.07, 55.29, 30.72 .

33a and 34a, diethyl 2-(1H-indol-3-yl)malonate

The protocol is analogous to that for 31a. Reaction time $=6 \mathrm{~h} .{ }^{1} \mathrm{H}$ NMR $(500$ $\left.\mathrm{MHz}, \mathrm{CDCl}_{3}\right) \delta 8.99(\mathrm{~s}, 1 \mathrm{H}), 7.58(\mathrm{~d}, J=8 \mathrm{~Hz}, 1 \mathrm{H}), 7.38(\mathrm{~d}, J=8 \mathrm{~Hz}, 1 \mathrm{H}), 7.21$ $\left(\mathrm{td}, J_{l}=1 \mathrm{~Hz}, J_{2}=7 \mathrm{~Hz}, 1 \mathrm{H}\right), 7.19\left(\mathrm{td}, J_{l}=1 \mathrm{~Hz}, J_{2}=7 \mathrm{~Hz}, 1 \mathrm{H}\right), 6.50(\mathrm{~d}, J=$ $1.5 \mathrm{~Hz}, 1 \mathrm{H}), 4.91(\mathrm{~s}, 1 \mathrm{H}), 4.29-4.20(\mathrm{~m}, 4 \mathrm{H}), 1.29(\mathrm{t}, J=7.5 \mathrm{~Hz}, 6 \mathrm{H}) ;{ }^{13} \mathrm{C} \mathrm{NMR}$ $\left(126 \mathrm{MHz}, \mathrm{CDCl}_{3}\right) \delta 167.23,136.48,128.60,127.64,122.35,120.52,119.94$, 111.23, 103.27, 62.40, 51.66, 14.02.

35a, ethyl 2-(1H-indol-3-yl)acetate

The protocol is analogous to that for 31a. Reaction time $=6 \mathrm{~h} .{ }^{1} \mathrm{H}$ NMR $(500$ $\left.\mathrm{MHz}, \mathrm{CDCl}_{3}\right) \delta 8.68(\mathrm{~s}, 1 \mathrm{H}), 7.55(\mathrm{~d}, J=8 \mathrm{~Hz}, 1 \mathrm{H}), 7.35(\mathrm{~d}, J=8 \mathrm{~Hz}, 1 \mathrm{H}), 7.16$ $\left(\mathrm{td}, J_{l}=1 \mathrm{~Hz}, J_{2}=7 \mathrm{~Hz}, 1 \mathrm{H}\right), 7.090\left(\mathrm{td}, J_{1}=1 \mathrm{~Hz}, J_{2}=7 \mathrm{~Hz}, 1 \mathrm{H}\right), 6.35(\mathrm{~s}, 1 \mathrm{H})$, $4.22(\mathrm{q}, J=7.5 \mathrm{~Hz}, 2 \mathrm{H}), 3.83(\mathrm{~s}, 2 \mathrm{H}), 1.30(\mathrm{t}, J=7.5 \mathrm{~Hz}, 3 \mathrm{H}) ;{ }^{13} \mathrm{C}$ NMR $(126$ $\left.\mathrm{MHz}, \mathrm{CDCl}_{3}\right) \delta 170.62,136.34,130.59,128.22,121.73,120.13,119.83,110.80$, $101.81,77.28,77.03,76.78,61.40,33.96,14.18$.

36a, a mixture of 4'-fluoro-2-methoxy-1,1'-biphenyl, 4'-fluoro-3-methoxy-1,1'biphenyl, 4-fluoro-4'-methoxy-1,1'-biphenyl

36a was prepared according to the standard procedure described previously using fluorobenzene $(2 \mathrm{~mL})$ as solvent. Reaction time $=24 \mathrm{~h}$. A mixture of $o-, m-$ and $p$ - isomers was obtained. The ratio of the isomers was determined by GCFID (see below). ${ }^{1} \mathrm{H}$ NMR (500 MHz, $\left.\mathrm{CDCl}_{3}\right) \delta 8.68(\mathrm{~m}, 8 \mathrm{H}), 3.84(\mathrm{~s}, 3 \mathrm{H}) ;{ }^{3} \mathrm{C}$ NMR $\left(126 \mathrm{MHz}, \mathrm{CDCl}_{3}\right) \delta 164.23,162.23,160.85,159.46,159.25,158.78$, 143.21, 132.86, 132.36, 130.57, 130.19, 128.78, 128.69, 128.45, 128.39, 128.27, $128.20,128.16,128.05,124.33,124.30,124.21,122.37,122.29,55.38,29.74$. 
Notes: To determine the isomeric ratio of the products of 1 and $\mathrm{C}_{6} \mathrm{H}_{5} \mathrm{~F}$ by the AgF/visible-light system, we prepared the $o$ - and $p$ - products using the standard Suziki coupling method (see below). Panel B shows the GC spectra of the reaction solutions shown in panel A. Hence the peaks (panel B, curve a) of the $o$-, $m$ - and $p$ - products could be correctly assigned. Then, for calculation of the isomeric ratio, we assumed that the response factors of the different isomers are equal.
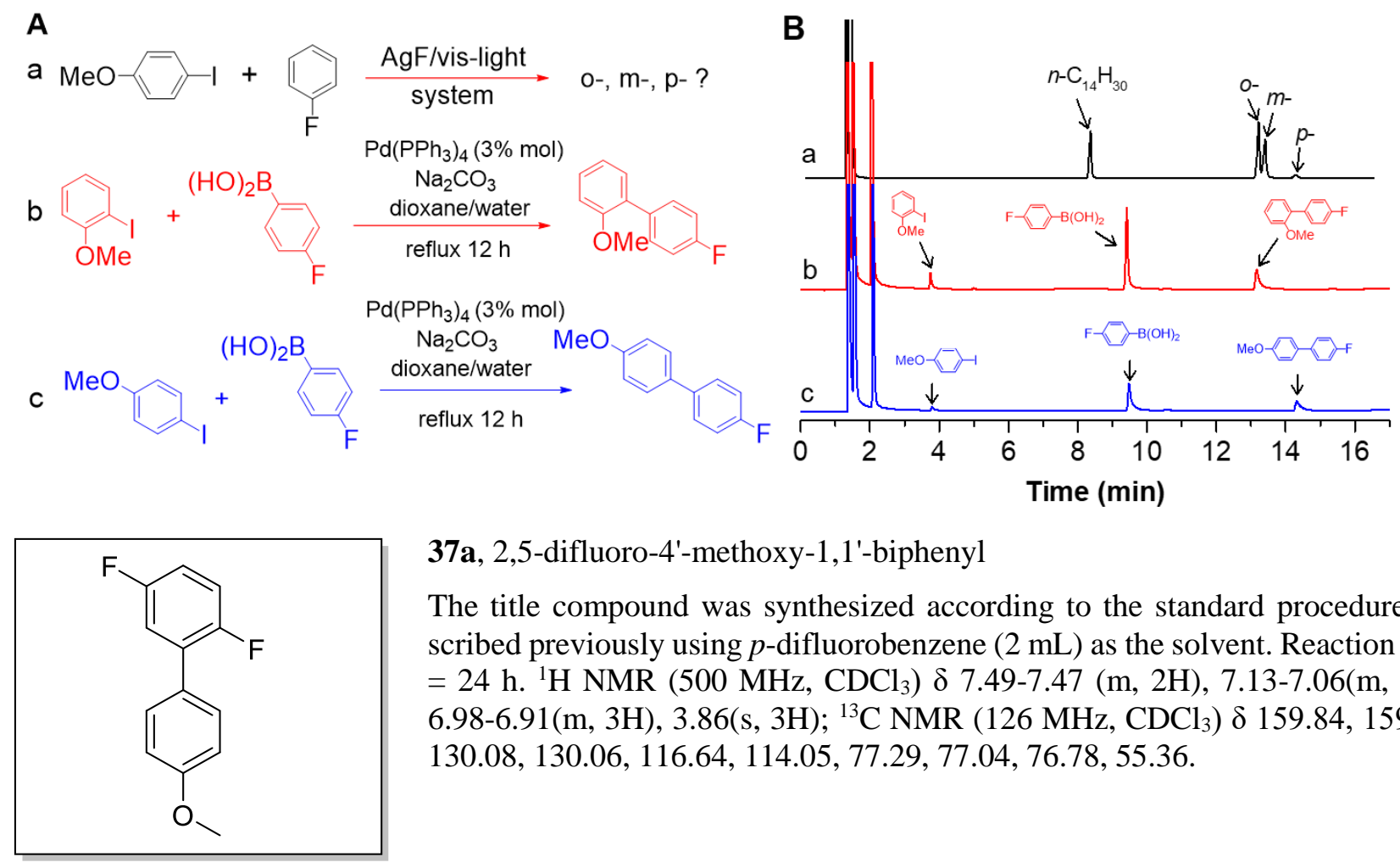

37a, 2,5-difluoro-4'-methoxy-1,1'-biphenyl

The title compound was synthesized according to the standard procedure described previously using $p$-difluorobenzene $(2 \mathrm{~mL})$ as the solvent. Reaction time $=24$ h. ${ }^{1} \mathrm{H}$ NMR $\left(500 \mathrm{MHz}, \mathrm{CDCl}_{3}\right) \delta$ 7.49-7.47 (m, 2H), 7.13-7.06(m, 2H), 6.98-6.91(m, 3H), 3.86(s, 3H); ${ }^{13} \mathrm{C}$ NMR $\left(126 \mathrm{MHz}, \mathrm{CDCl}_{3}\right) \delta$ 159.84, 159.55, $130.08,130.06,116.64,114.05,77.29,77.04,76.78,55.36$.

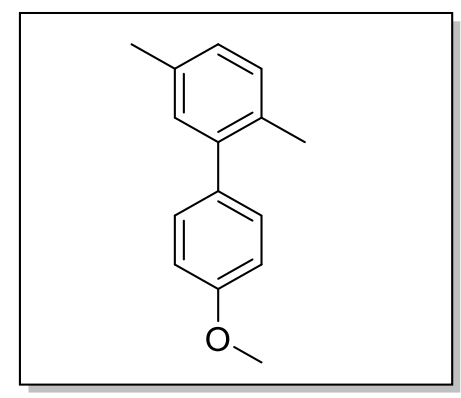

38a, 4'-methoxy-2,5-dimethyl-1,1'-biphenyl

The title compound was synthesized according to the standard procedure described previously using $p$-xylene $(2 \mathrm{~mL})$ as the solvent. Reaction time $=24 \mathrm{~h}$. ${ }^{1} \mathrm{H}$ NMR $\left(500 \mathrm{MHz}, \mathrm{CDCl}_{3}\right) \delta$ 7.25-7.23 (m, 2H), 7.16-7.14 (m,1H), 7.05-7.04 $(\mathrm{m}, 2 \mathrm{H}), 6.95-6.93(\mathrm{~m}, 2 \mathrm{H}), 3.84(\mathrm{~s}, 3 \mathrm{H}), 2.34(\mathrm{~s}, 3 \mathrm{H}), 2.23(\mathrm{~s}, 3 \mathrm{H}) ;{ }^{13} \mathrm{C}$ NMR $\left(126 \mathrm{MHz}, \mathrm{CDCl}_{3}\right) \delta 158.47,141.38,135.17,134.53,132.31,130.66,130.23$, 127.67, 113.46, 55.30, 20.92, 20.04.

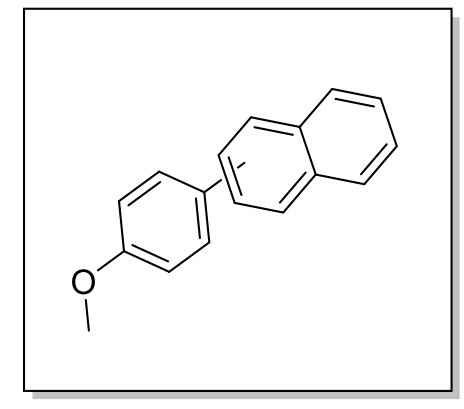

39a, a mixture of 1-(4-methoxyphenyl)naphthalene and 2-(4-methoxyphenyl)naphthalene

The reaction was performed using 1-iodo-4-methoxybenzene $(0.086 \mathrm{mmol}, 1$ eq.), naphthaline ( $0.43 \mathrm{mmol}, 5 \mathrm{eq})$ and $\mathrm{AgF}(0.15 \mathrm{mmol}, 2 \mathrm{eq})$ under visible light irradiation. $2 \mathrm{~mL} \mathrm{MeCN}$ was the solvent. Reaction time $=12 \mathrm{~h} .{ }^{1} \mathrm{H}$ NMR $\left(500 \mathrm{MHz}, \mathrm{CDCl}_{3}\right) \delta$ 7.94-7.84 (m, 3H), 7.53-7.41 (m, 6H), 7.05-7.03 (m, 2H); $3.90(\mathrm{~s}, 3 \mathrm{H}) ;{ }^{13} \mathrm{C}$ NMR $\left(126 \mathrm{MHz}, \mathrm{CDCl}_{3}\right) \delta 158.95,139.93,133.85,133.14$, $131.84,131.14,128.45,128.28,127.36,126.93,126.09,125.94,125.73,125.43$, 114.34, 113.73, 55.39. 
To determine the isomeric ratio of the products of $\mathbf{1}$ and naphthalene by the AgF/visible-light system, we prepared the $\alpha$-product using the standard Suziki coupling method (see below). By comparing the retention time, the $\alpha$ and $\beta$-products were successfully assigned.

A

a<smiles>Ic1cccc2ccccc12</smiles>

b

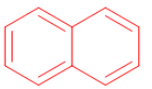

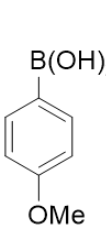

$\underbrace{}_{\mathrm{OMe}}$
$\mathrm{Pd}\left(\mathrm{PPh}_{3}\right)_{4}(3 \% \mathrm{~mol})$

$\mathrm{Na}_{2} \mathrm{CO}_{3}$ dioxane/water

reflux $12 \mathrm{~h}$

$\mathrm{AgF} /$ visible light

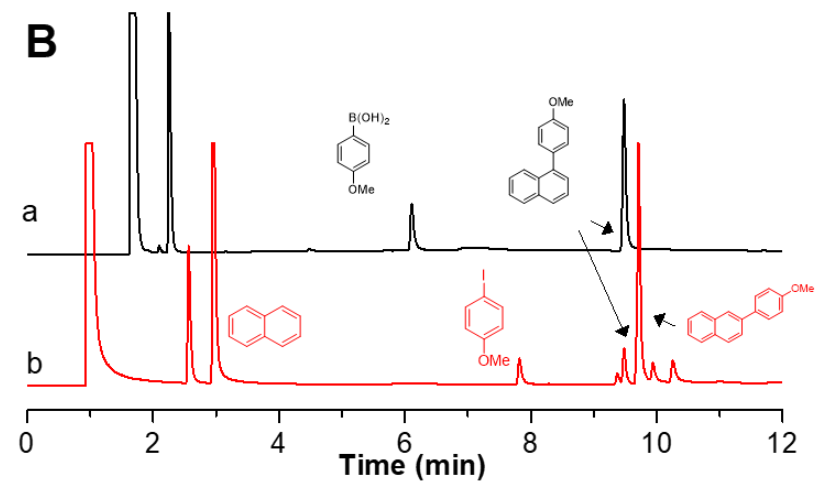


benzene, 9H

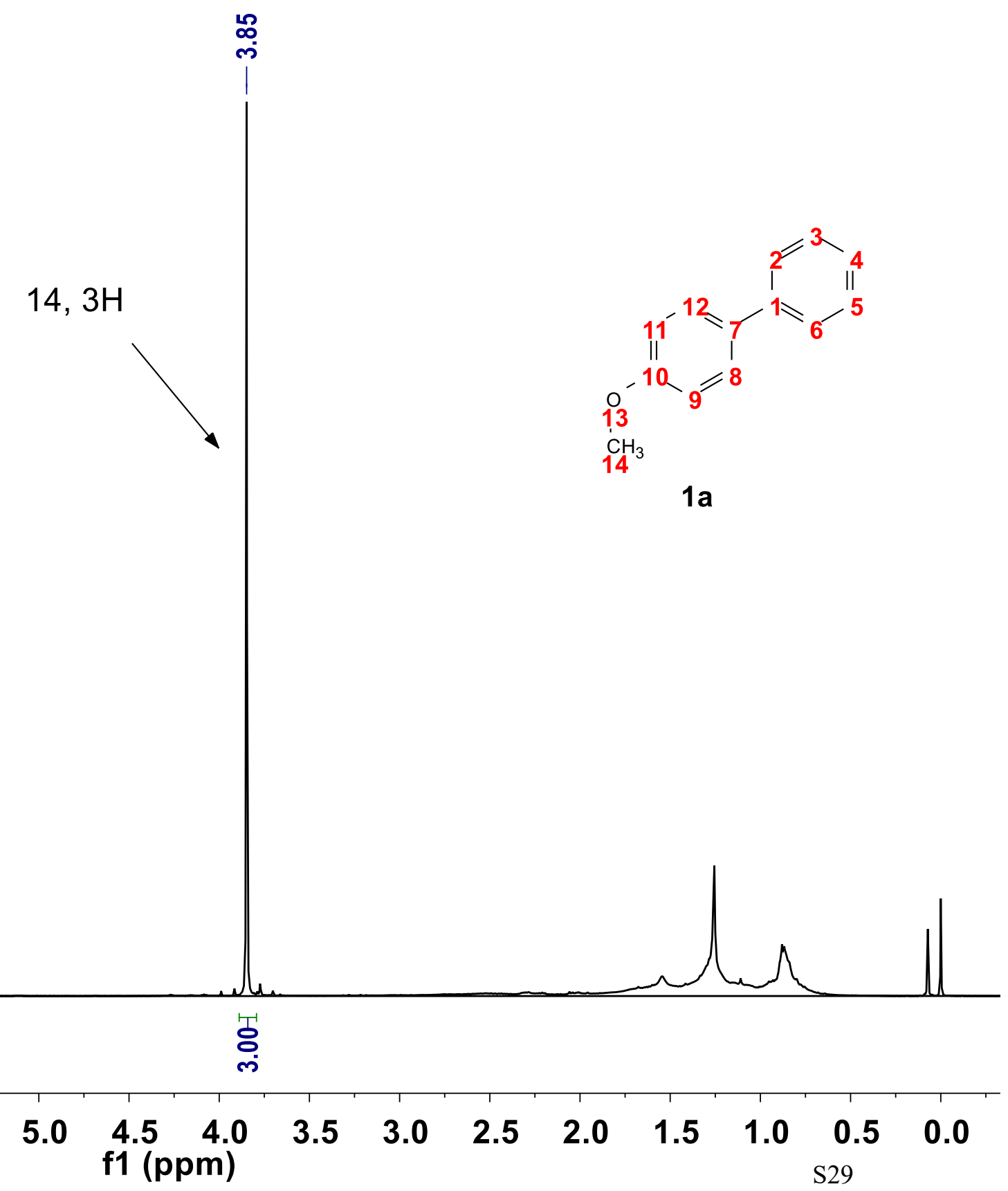



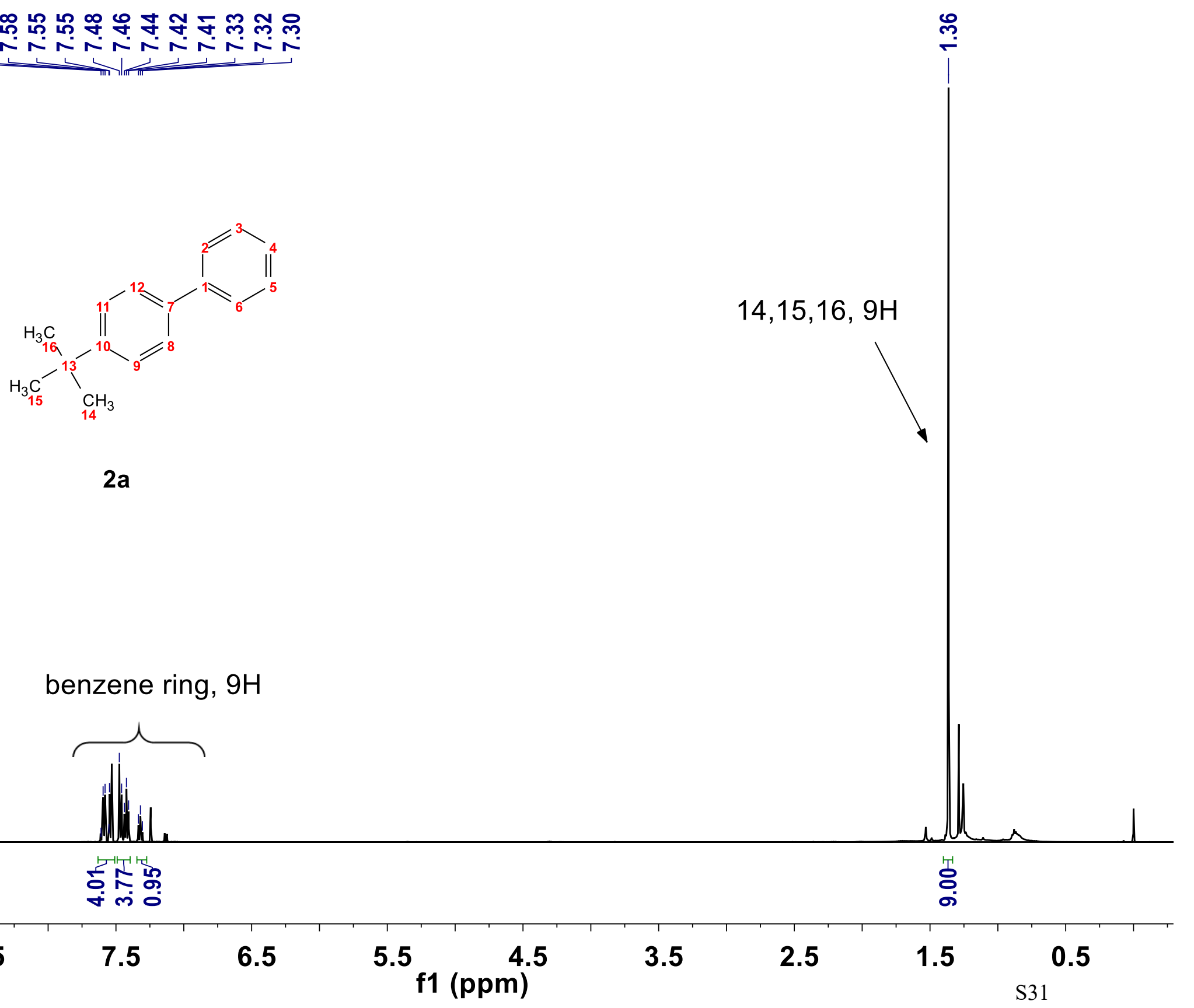


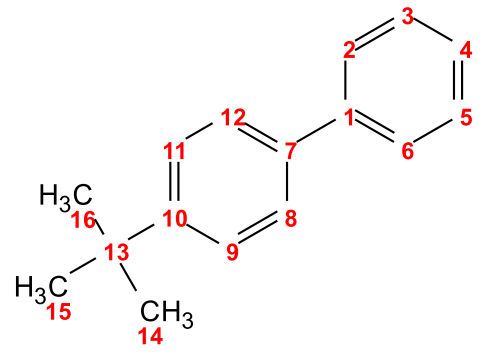

$2 a$

\begin{tabular}{|c|c|c|c|c|c|c|c|c|c|c|}
\hline 200 & 180 & 160 & 140 & 120 & $\begin{array}{c}100 \\
\mathrm{f} 1 \text { (ppm) }\end{array}$ & 80 & 60 & 40 & 20 & $2^{0}$ \\
\hline
\end{tabular}




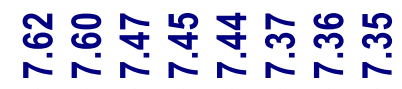

垈

benzene ring, $10 \mathrm{H}$

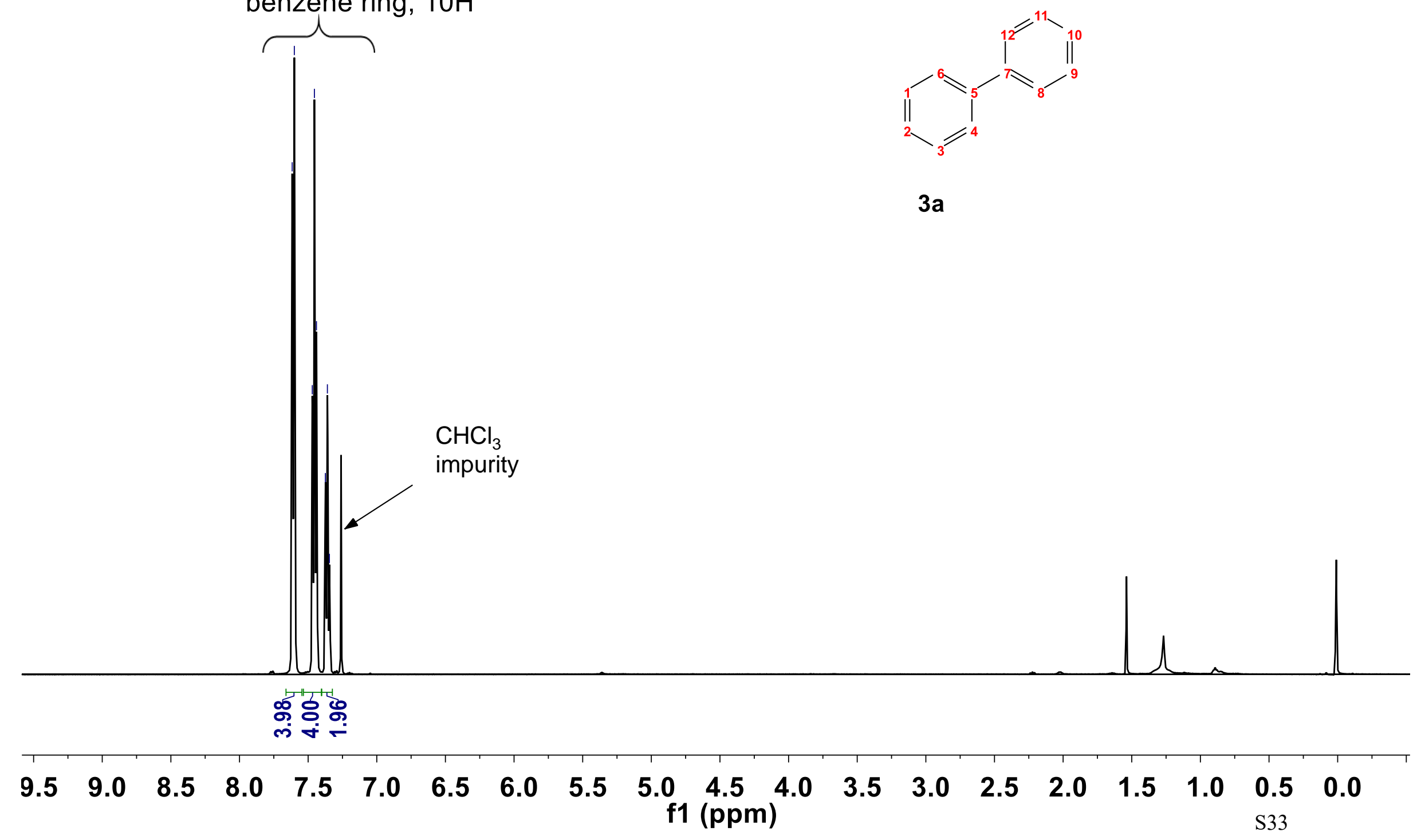



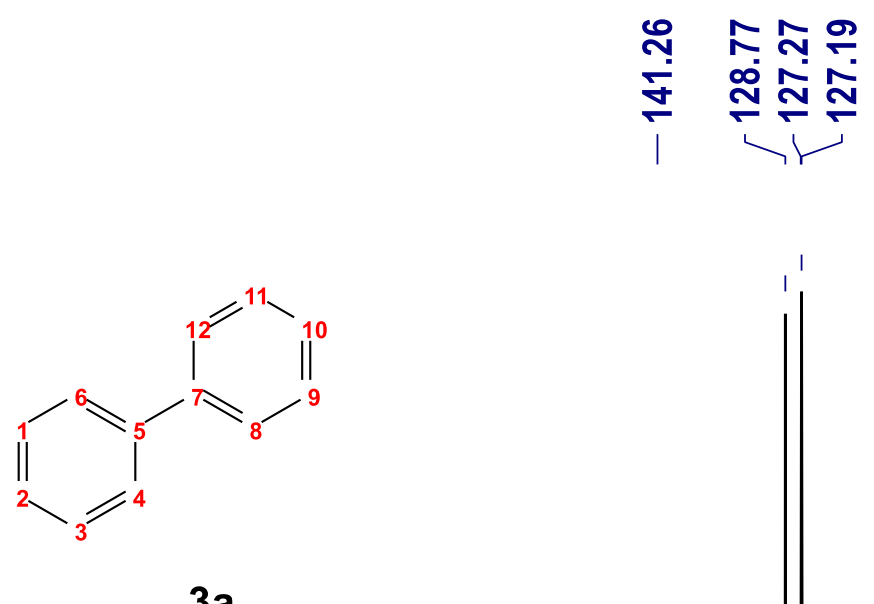

$3 a$

\begin{tabular}{|c|c|c|c|c|c|c|c|c|c|c|}
\hline 200 & 180 & 160 & 140 & 120 & $\begin{array}{l}100 \\
\mathrm{f} 1 \text { (ppm) }\end{array}$ & 80 & 60 & 40 & 20 & ${ }_{4}^{0}$ \\
\hline
\end{tabular}




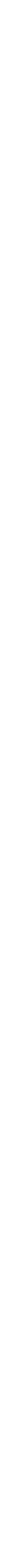




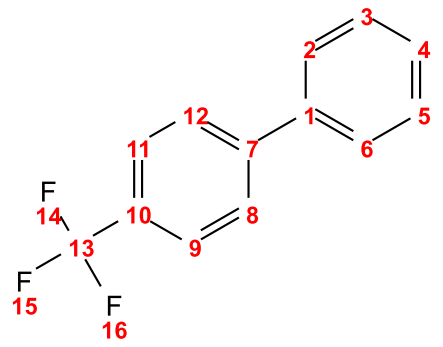

$4 a$

\begin{tabular}{|c|c|c|c|c|c|c|c|c|c|c|}
\hline 200 & 180 & 160 & 140 & 120 & $\begin{array}{l}100 \\
\mathrm{f} 1(\mathrm{ppm})\end{array}$ & 80 & 60 & 40 & 20 & 6 \\
\hline
\end{tabular}


$\mathrm{CHCl}_{3}$

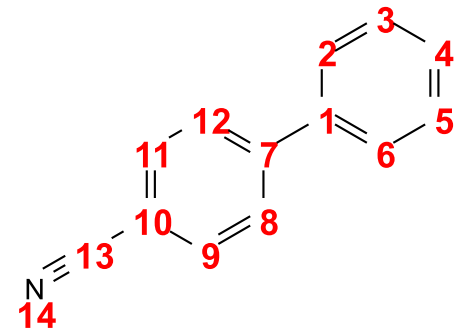

$5 a$

impurity

benzene ring, 9H कृ की

\begin{tabular}{|c|c|c|c|c|c|c|c|c|c|}
\hline 0.0 & 9.0 & 8.0 & 7.0 & 6.0 & $\begin{array}{l}5.0 \quad 4.0 \\
f 1(p p m)\end{array}$ & 3.0 & 2.0 & 1.0 & $\begin{array}{r}\mathbf{0 . 0} \\
\mathrm{S} 37\end{array}$ \\
\hline
\end{tabular}




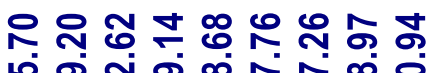

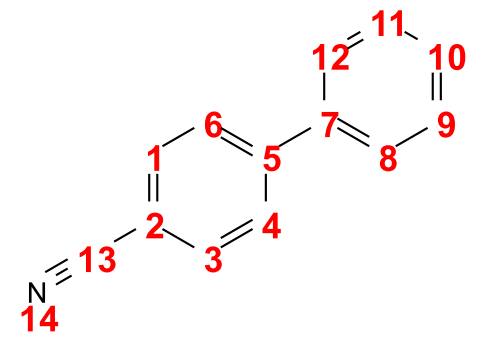

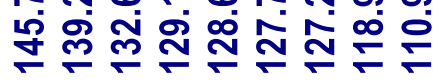

$5 a$

\begin{tabular}{|c|c|c|c|c|c|c|c|c|c|c|}
\hline 200 & 180 & 160 & 140 & 120 & $\begin{array}{l}100 \\
\mathrm{f} 1 \text { (ppm) }\end{array}$ & 80 & 60 & 40 & 20 & 8 \\
\hline
\end{tabular}




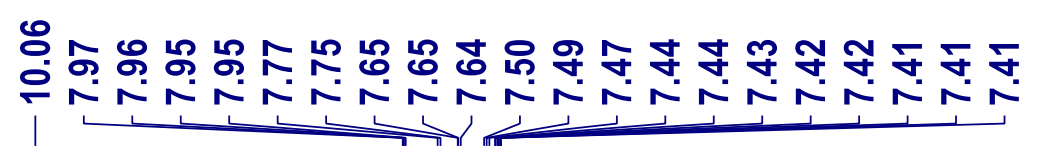

$14,1 \mathrm{H}$

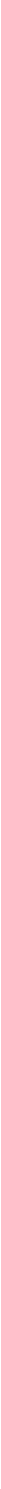




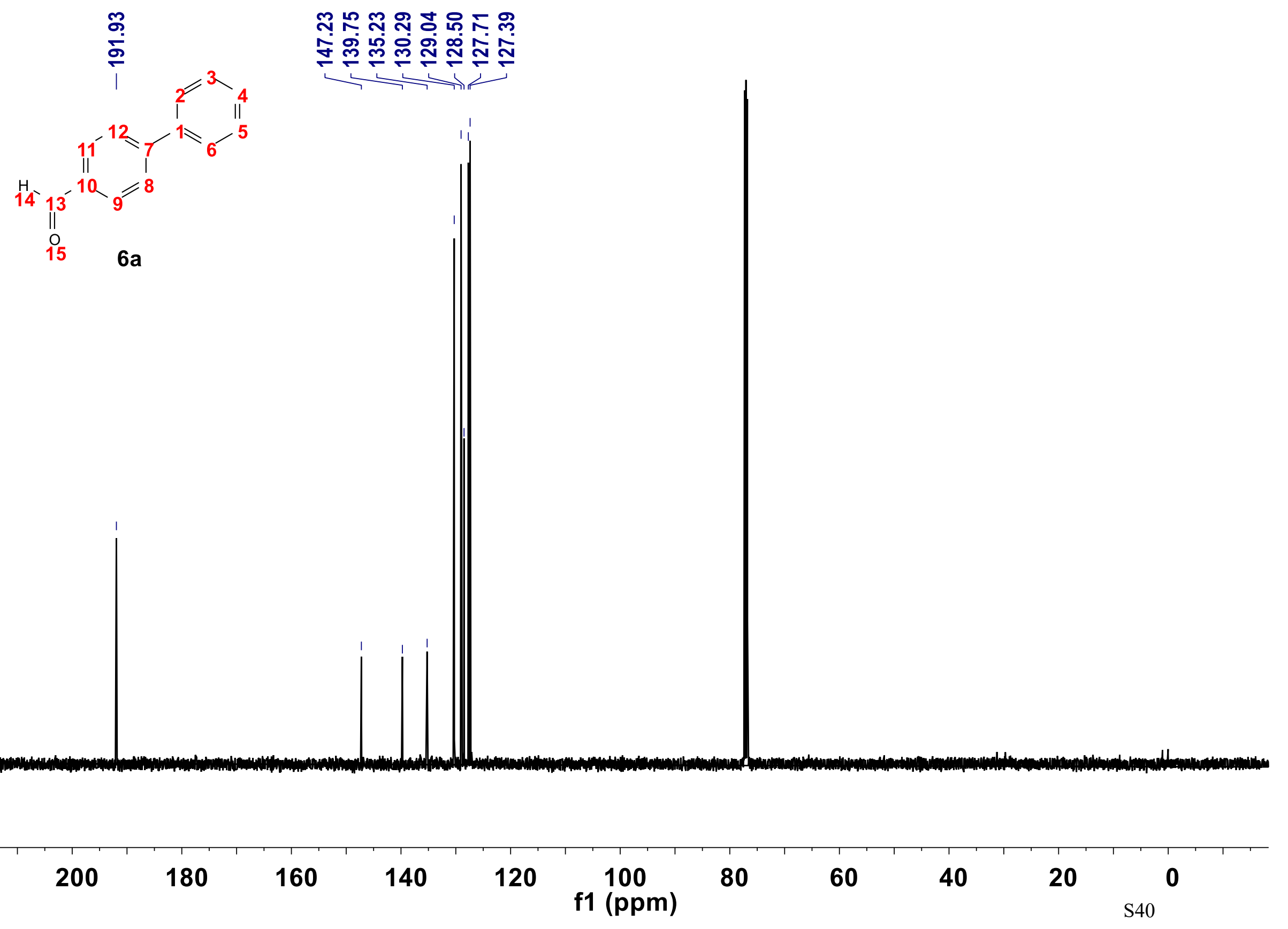




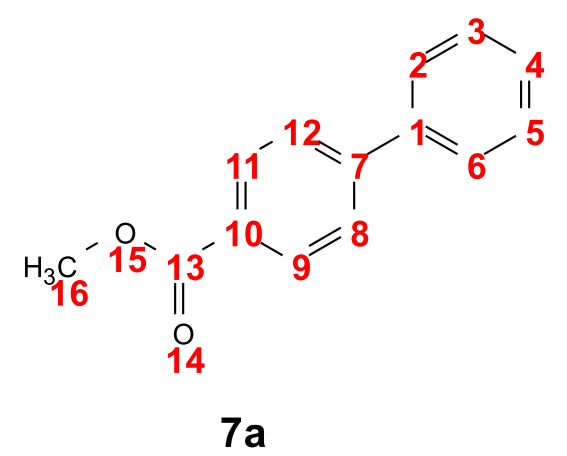

Benzene ring, $9 \mathrm{H}$

$\mathrm{CHCl} 3$ impurity

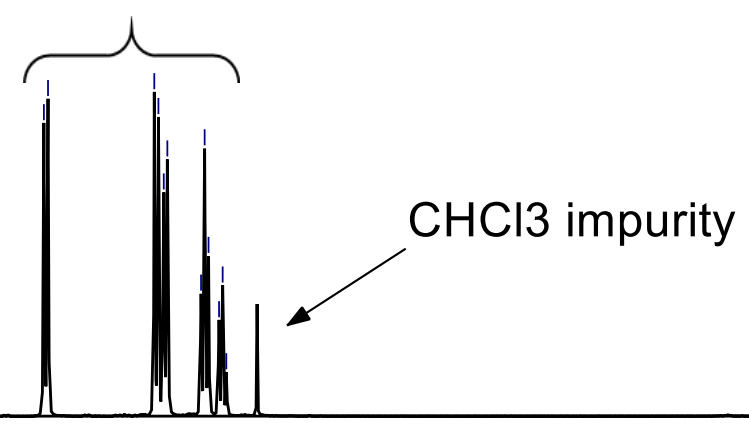

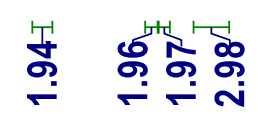

畓

$\begin{array}{lllllllllllllllllll}9.0 & 8.5 & 8.0 & 7.5 & 7.0 & 6.5 & 6.0 & 5.5 & \begin{array}{c}5.0 \\ \mathrm{f} 1\end{array} \underset{(\mathrm{ppm})}{4.5} & 4.0 & 3.5 & 3.0 & 2.5 & 2.0 & 1.5 & 1.0 & 0.5 & 0.0\end{array}$ 


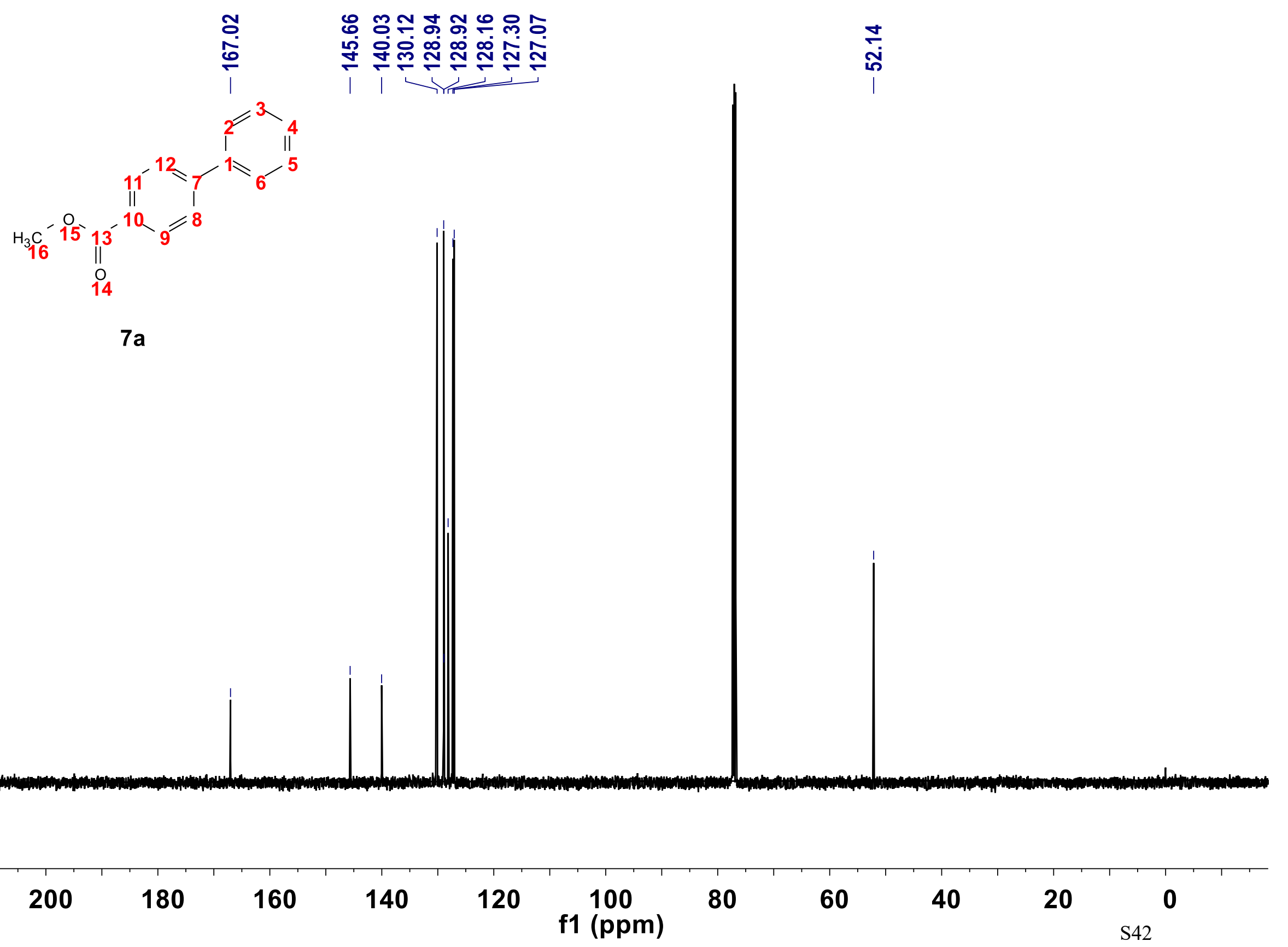


benezene ring, $9 \mathrm{H}$

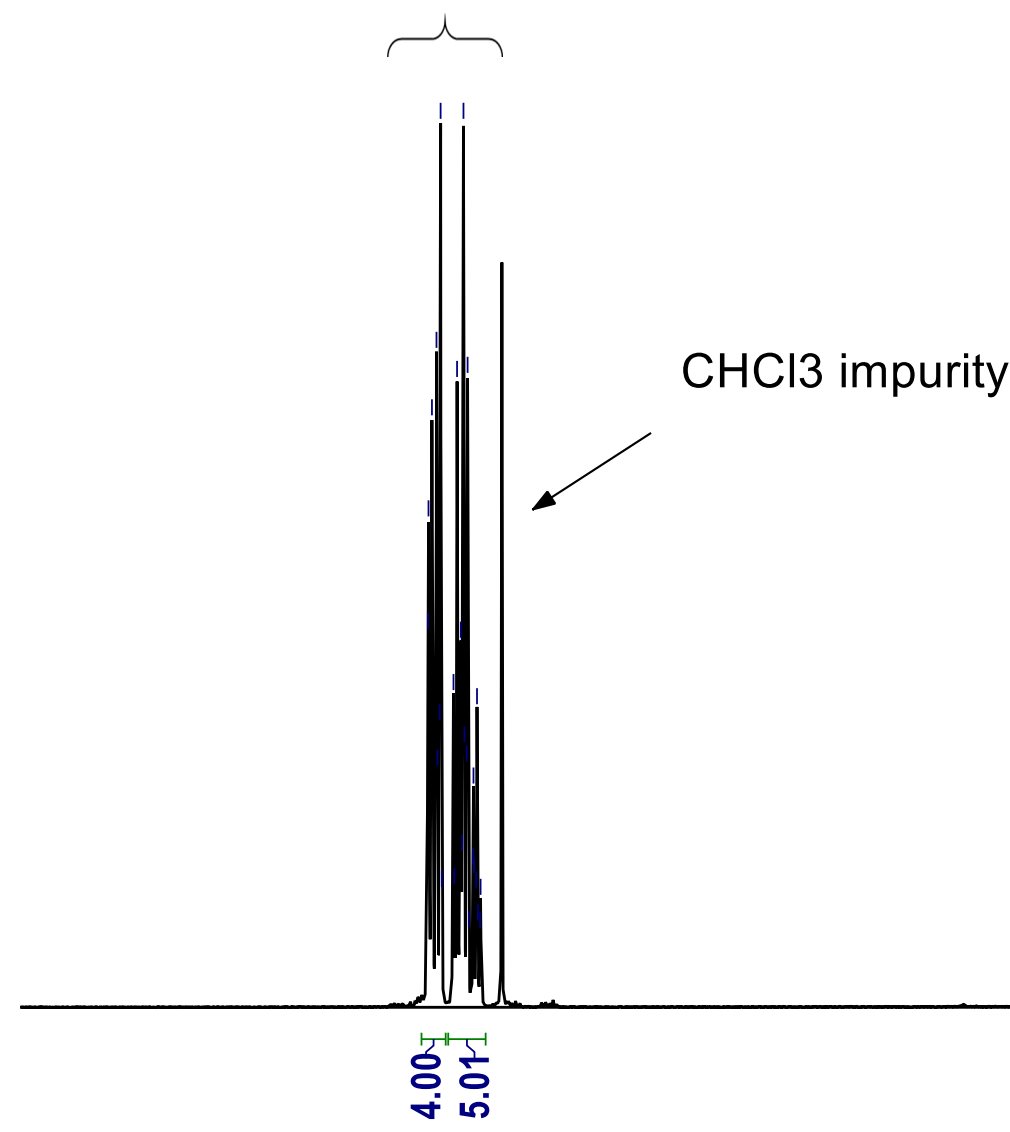

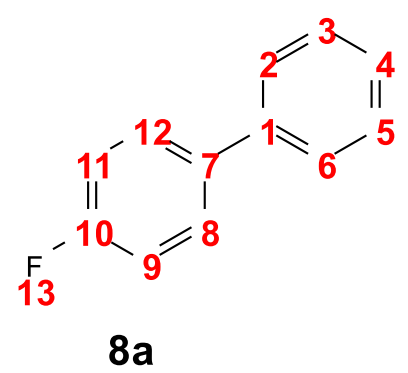

$8 a$

\section{$\begin{array}{lllllllllllllllllll}9.0 & 8.5 & 8.0 & 7.5 & 7.0 & 6.5 & 6.0 & 5.5 & 5.0 & 4.5 & 4.0 & 3.5 & 3.0 & 2.5 & 2.0 & 1.5 & 1.0 & 0.5 & 0.0\end{array}$ f1 (ppm)




\section{Benzene ring, $9 \mathrm{H}$}

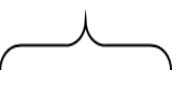

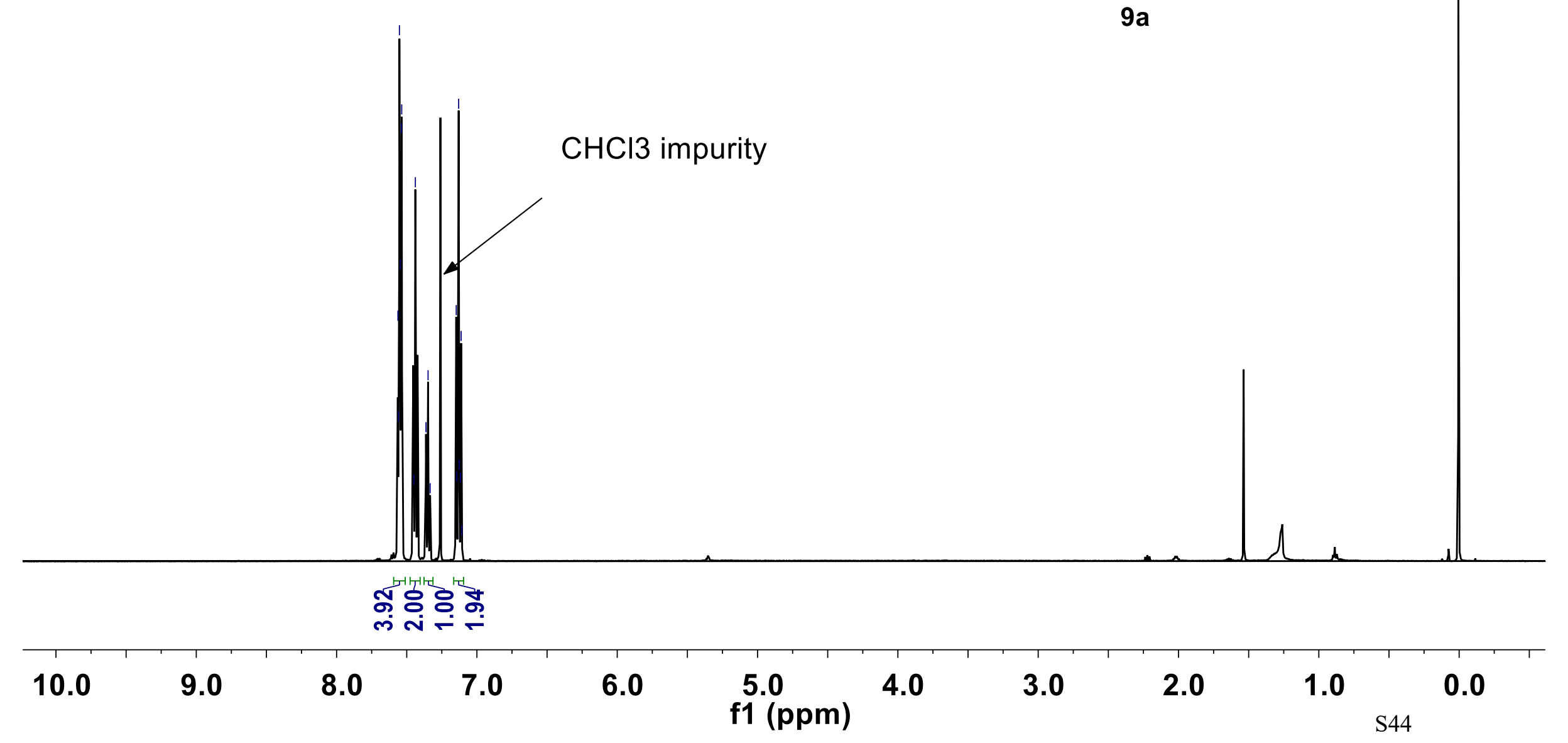

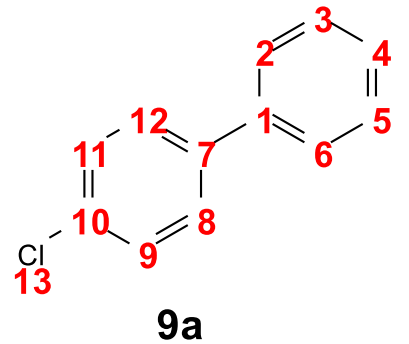




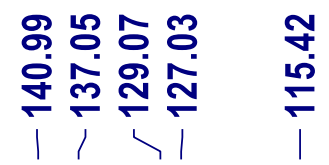
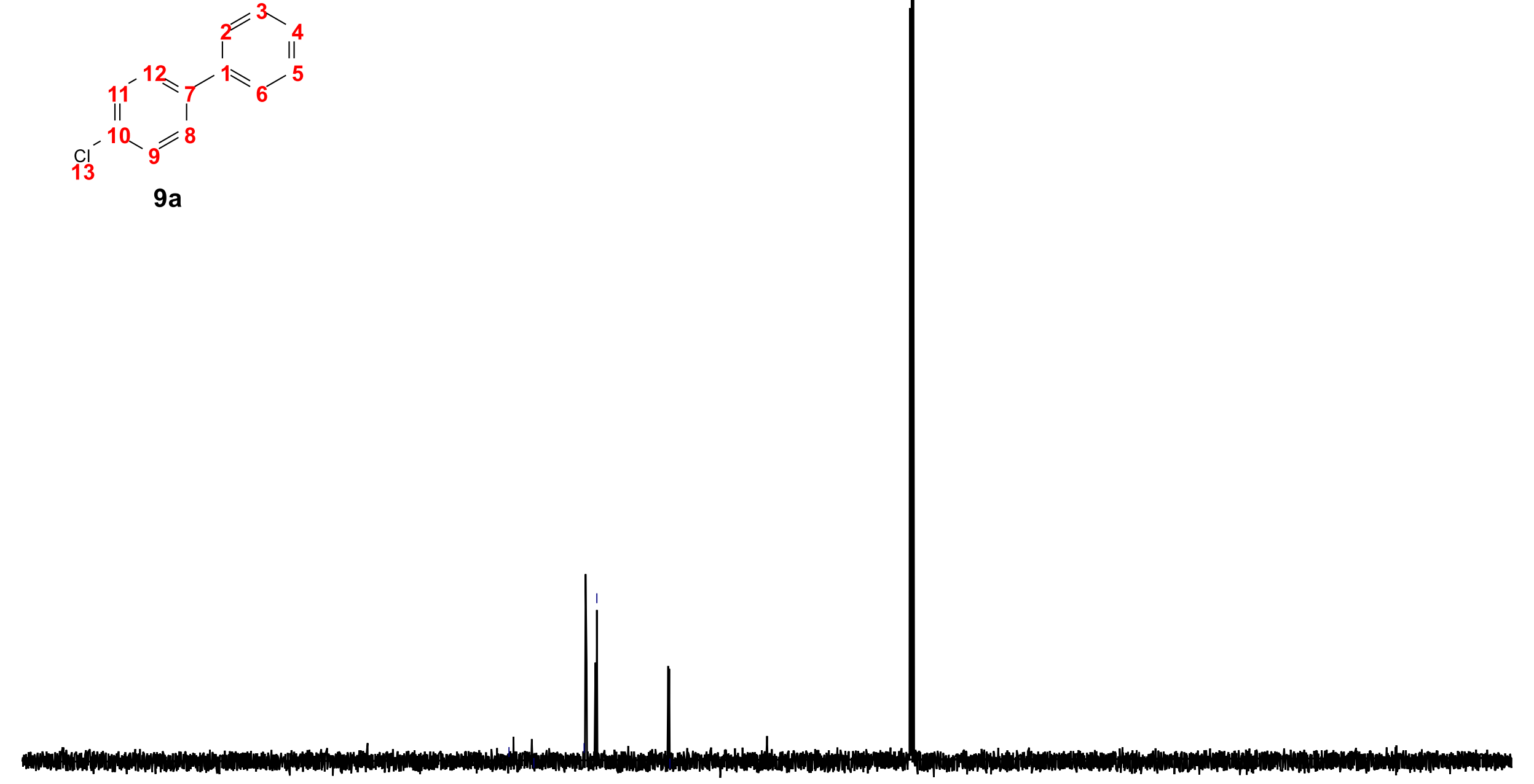

\begin{tabular}{|c|c|c|c|c|c|c|c|c|c|c|}
\hline 200 & 180 & 160 & 140 & 120 & $\begin{array}{l}100 \\
\mathrm{f} 1 \text { (ppm) }\end{array}$ & 80 & 60 & 40 & 20 & ${ }_{5}^{0}$ \\
\hline
\end{tabular}


Benzene ring, $9 \mathrm{H}$

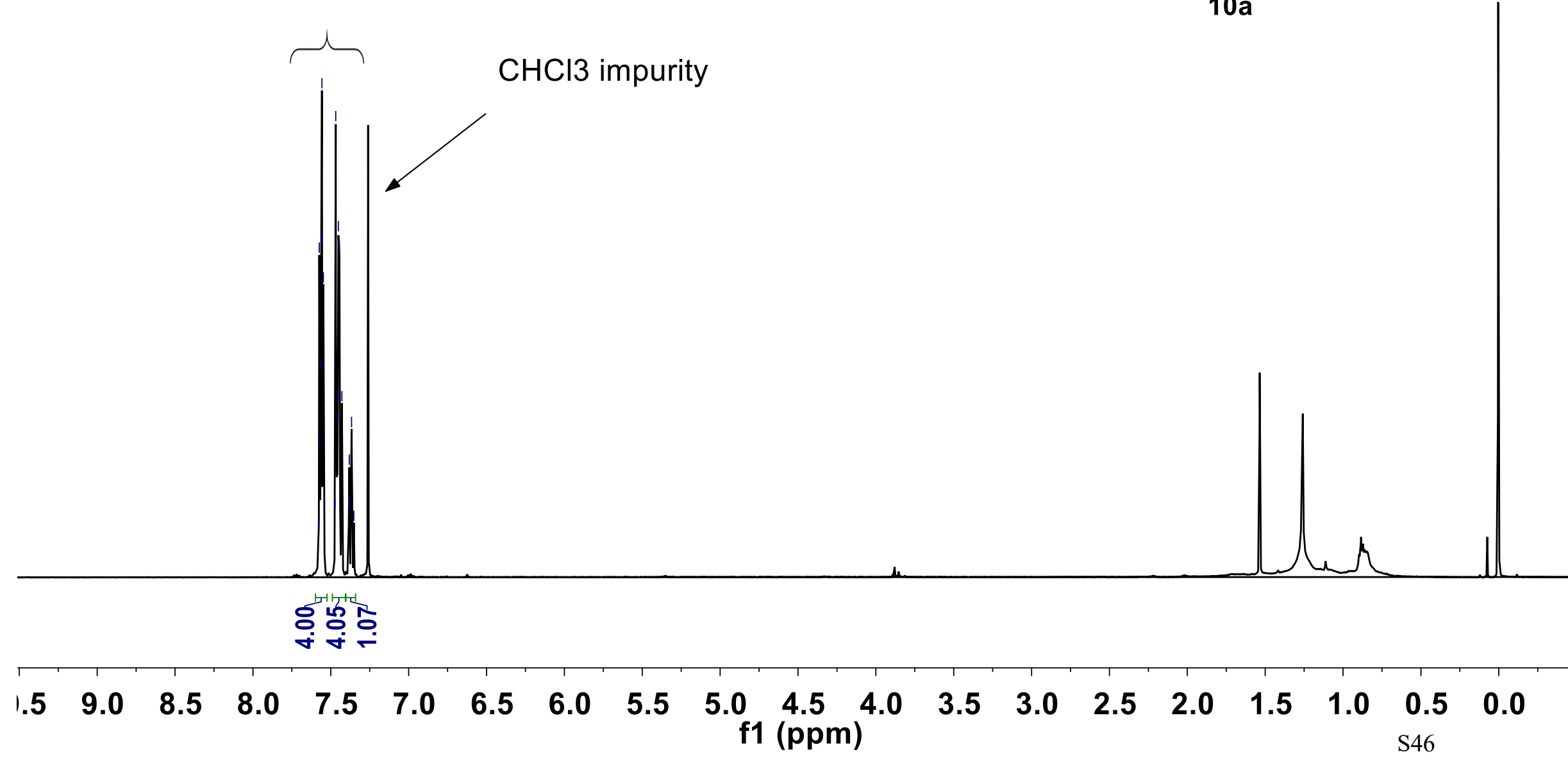




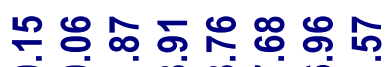

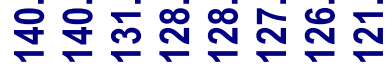
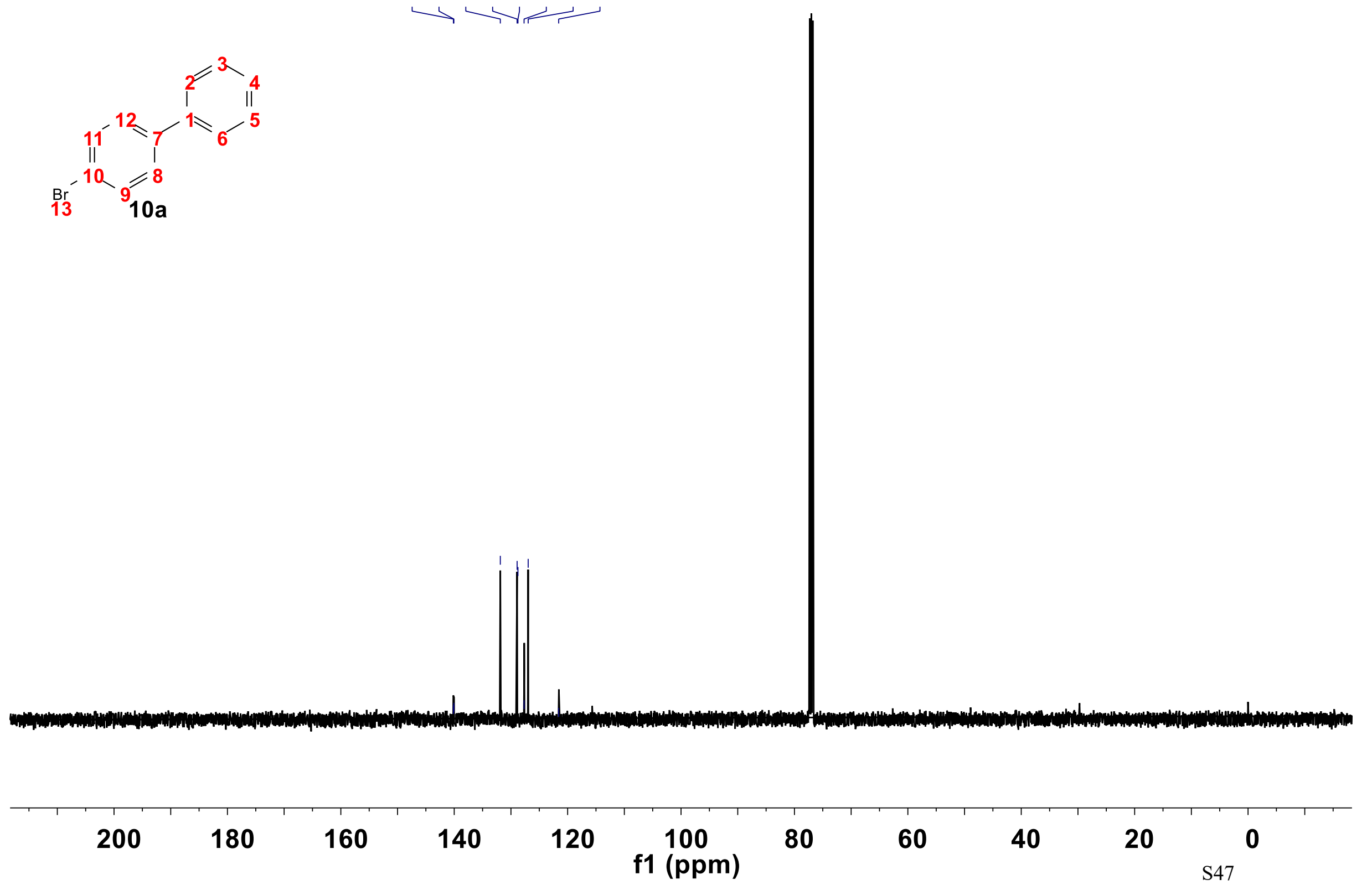

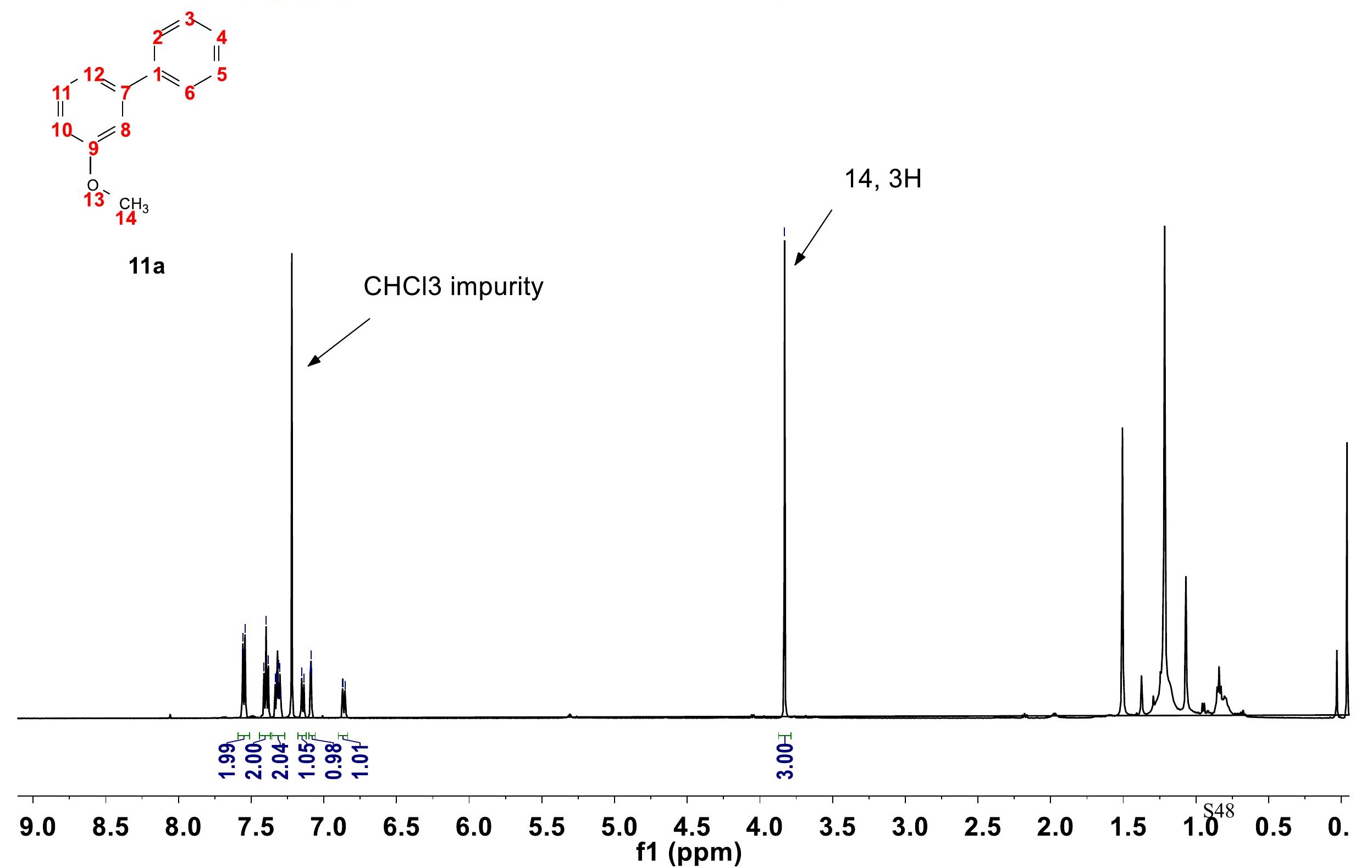


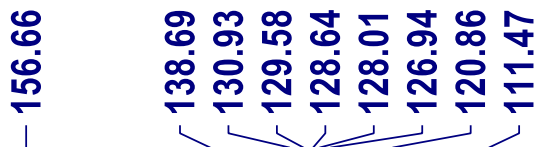

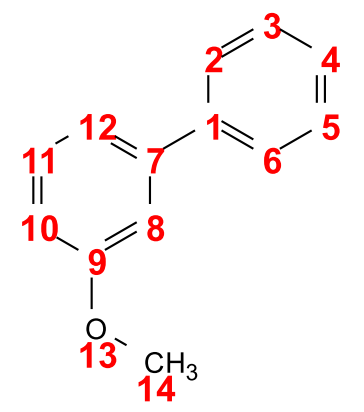

11a

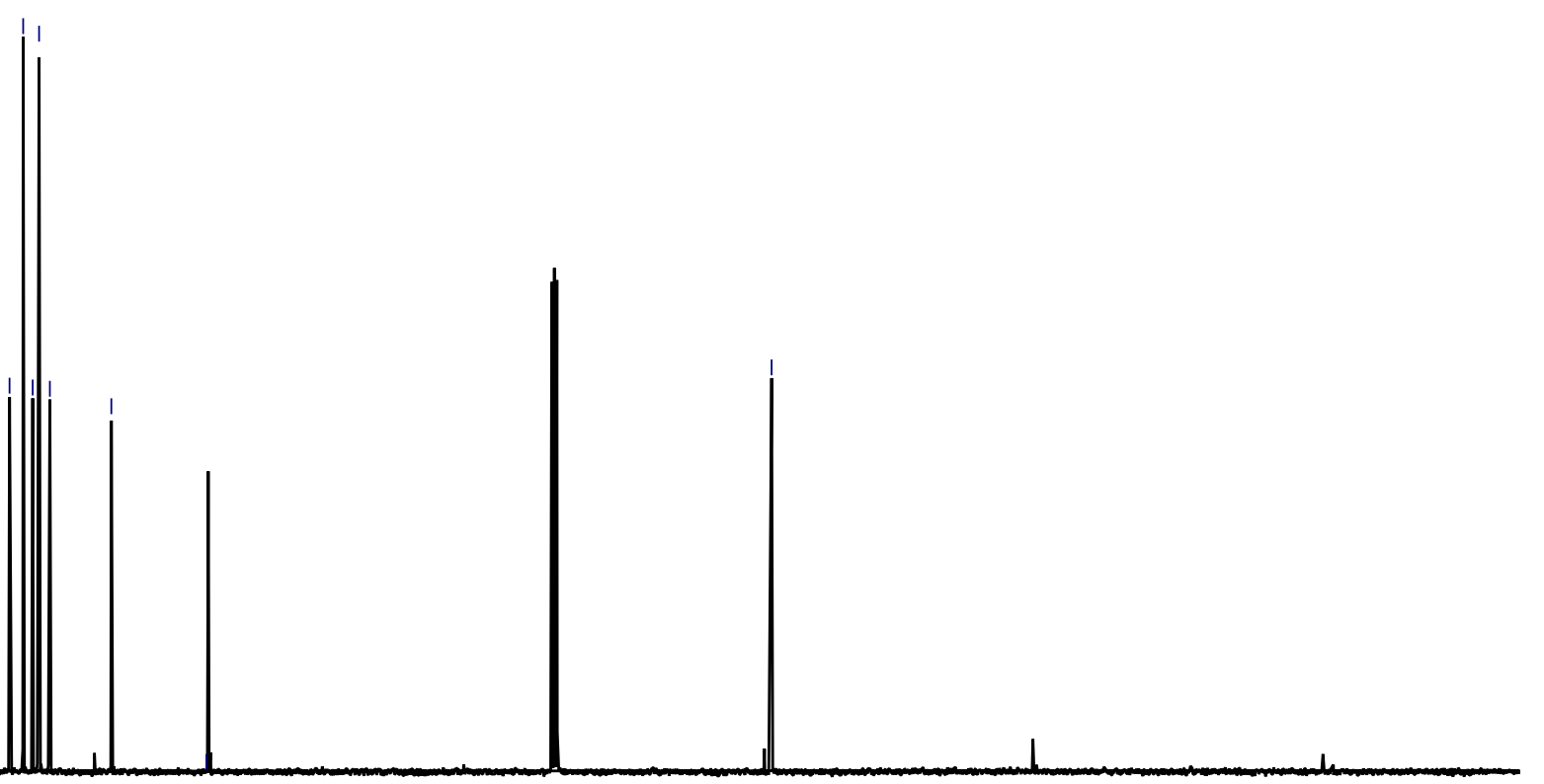

60

40

20 


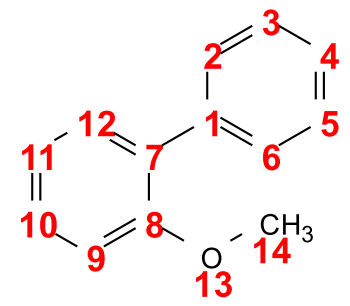

$12 a$

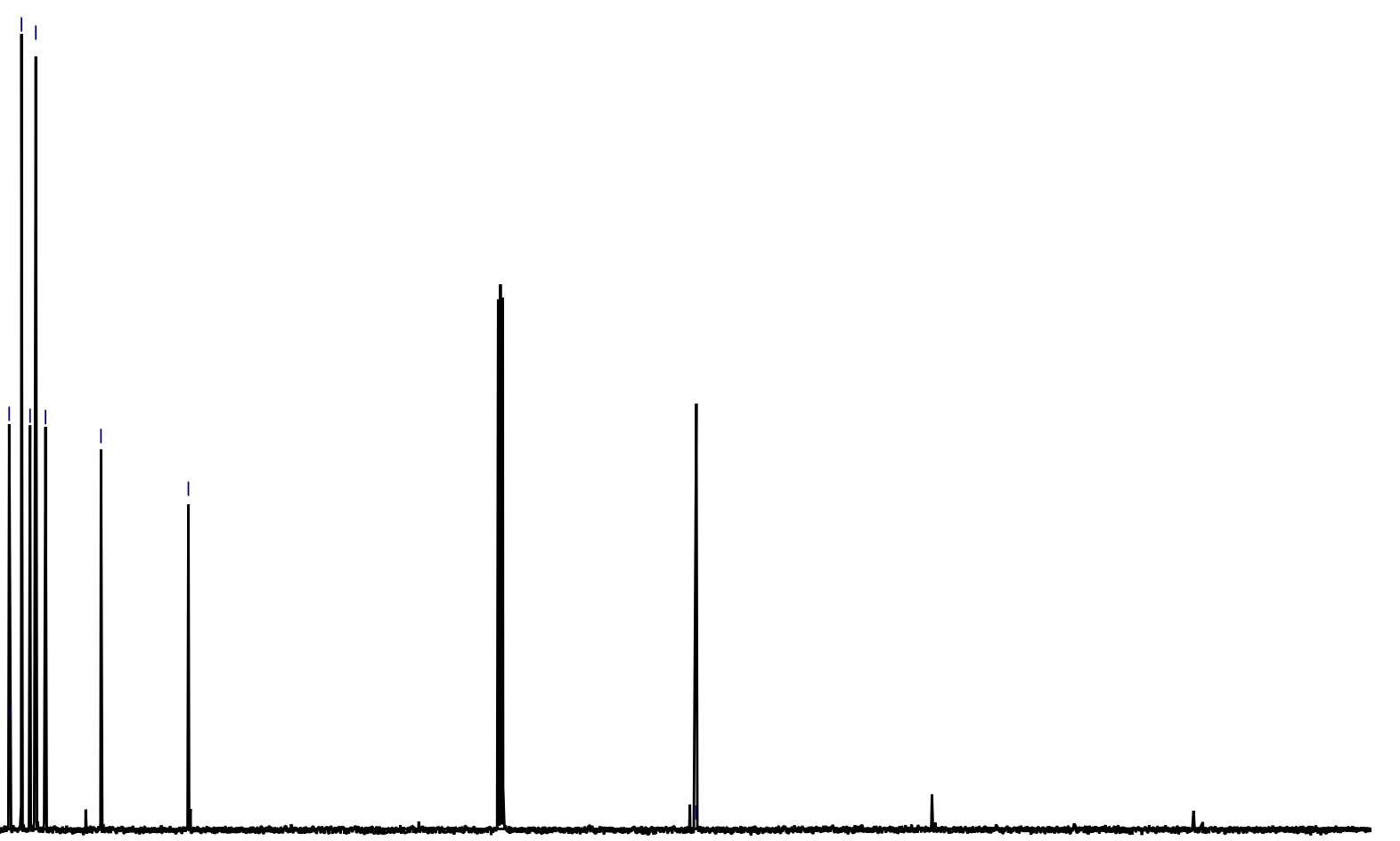



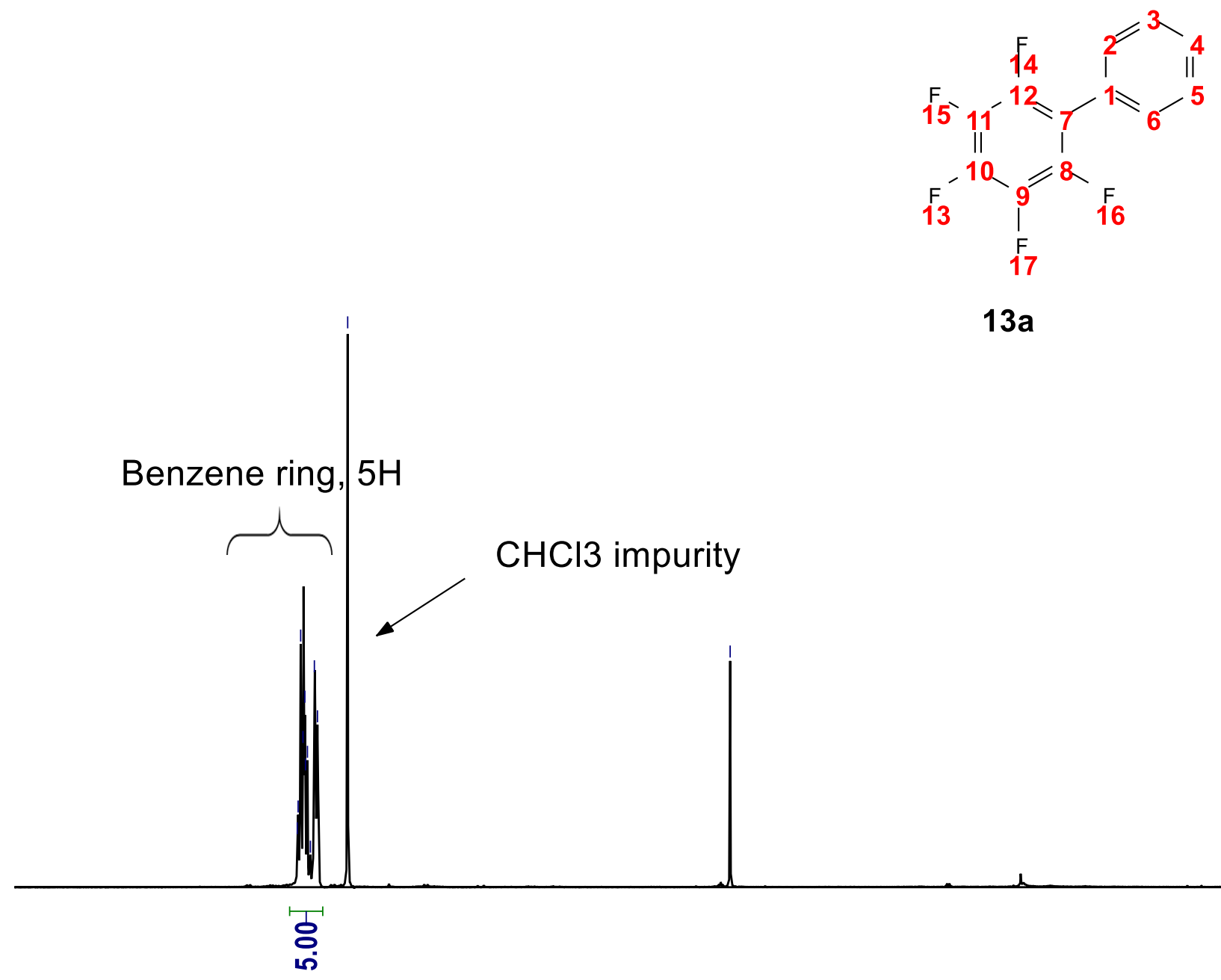

$13 a$

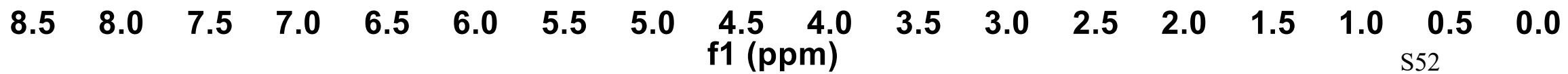




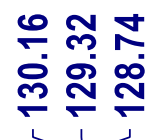

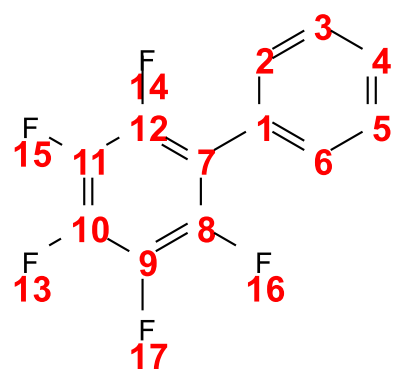

$13 a$

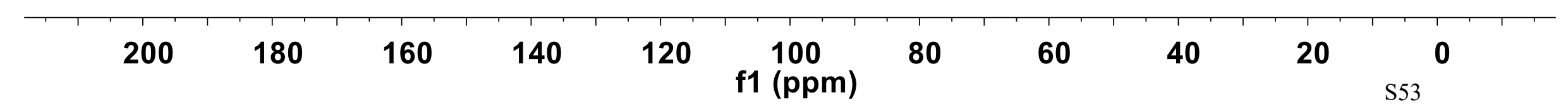



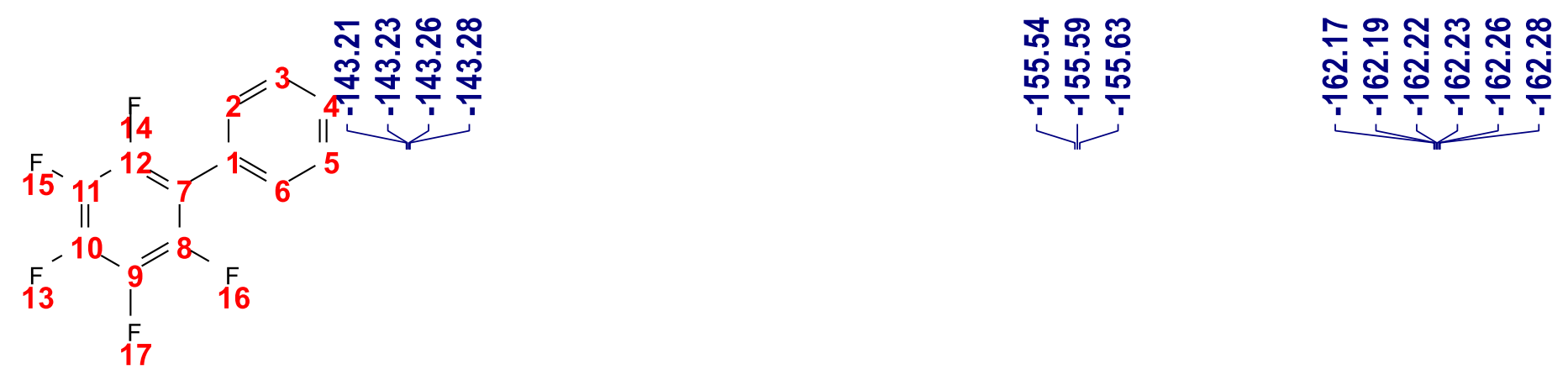

$13 a$

$12,16,2 \mathrm{~F}$

$\mid$

\begin{tabular}{|c|c|c|c|}
\hline & & 。্. & , \\
\hline-137 & -146 & $f 1(p p m)$ & -164 \\
\hline
\end{tabular}




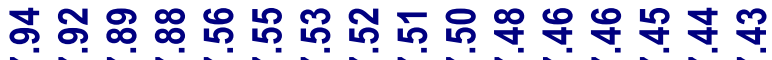

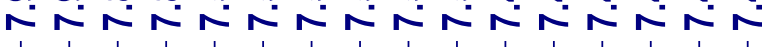

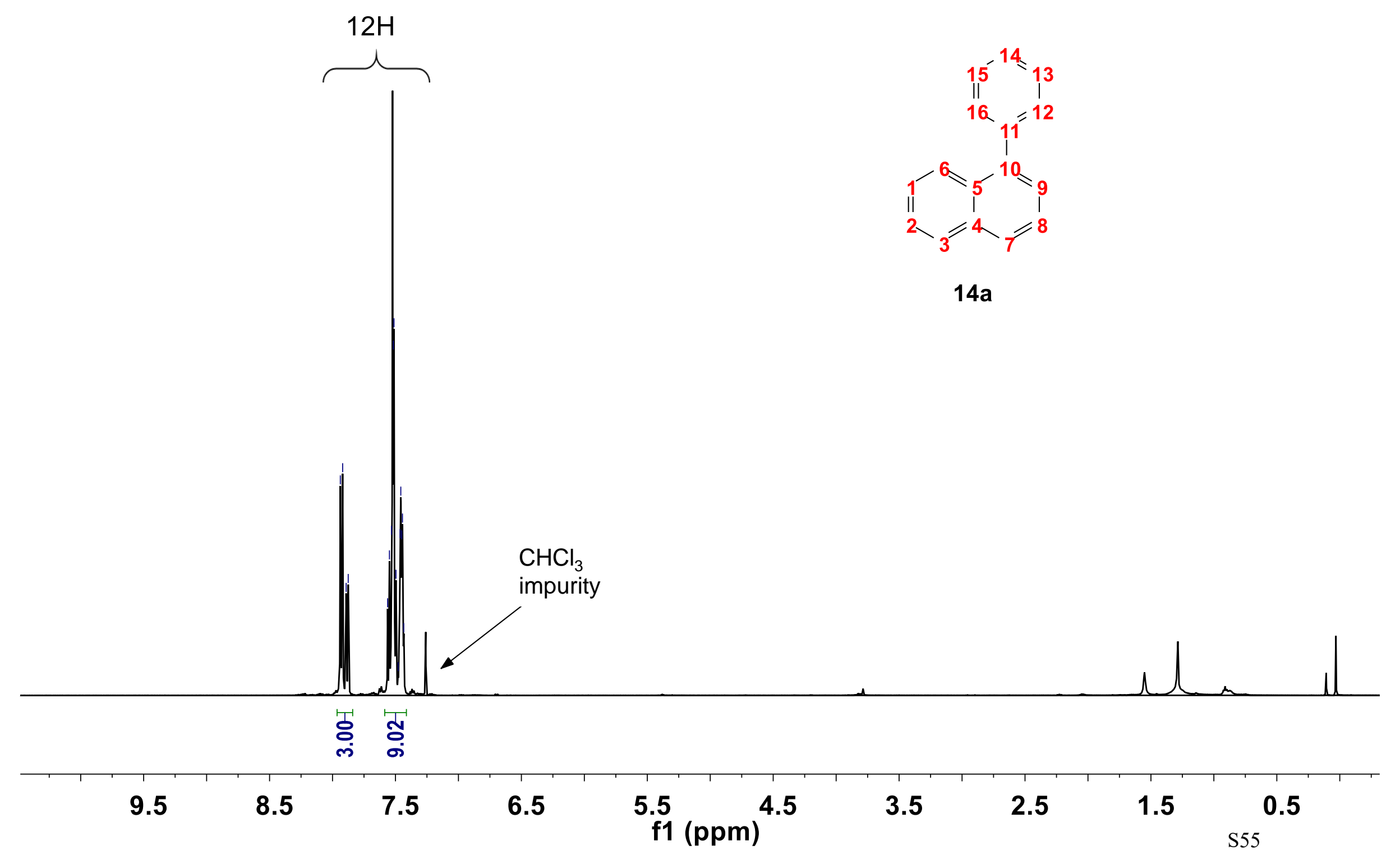




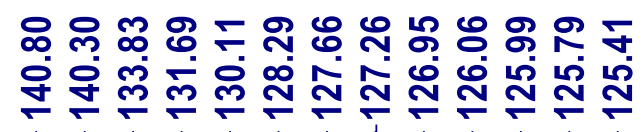

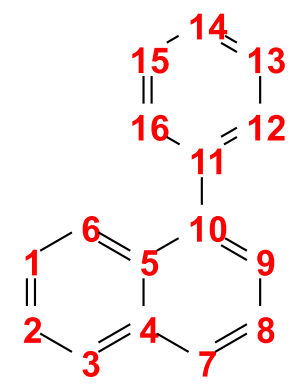

$14 a$

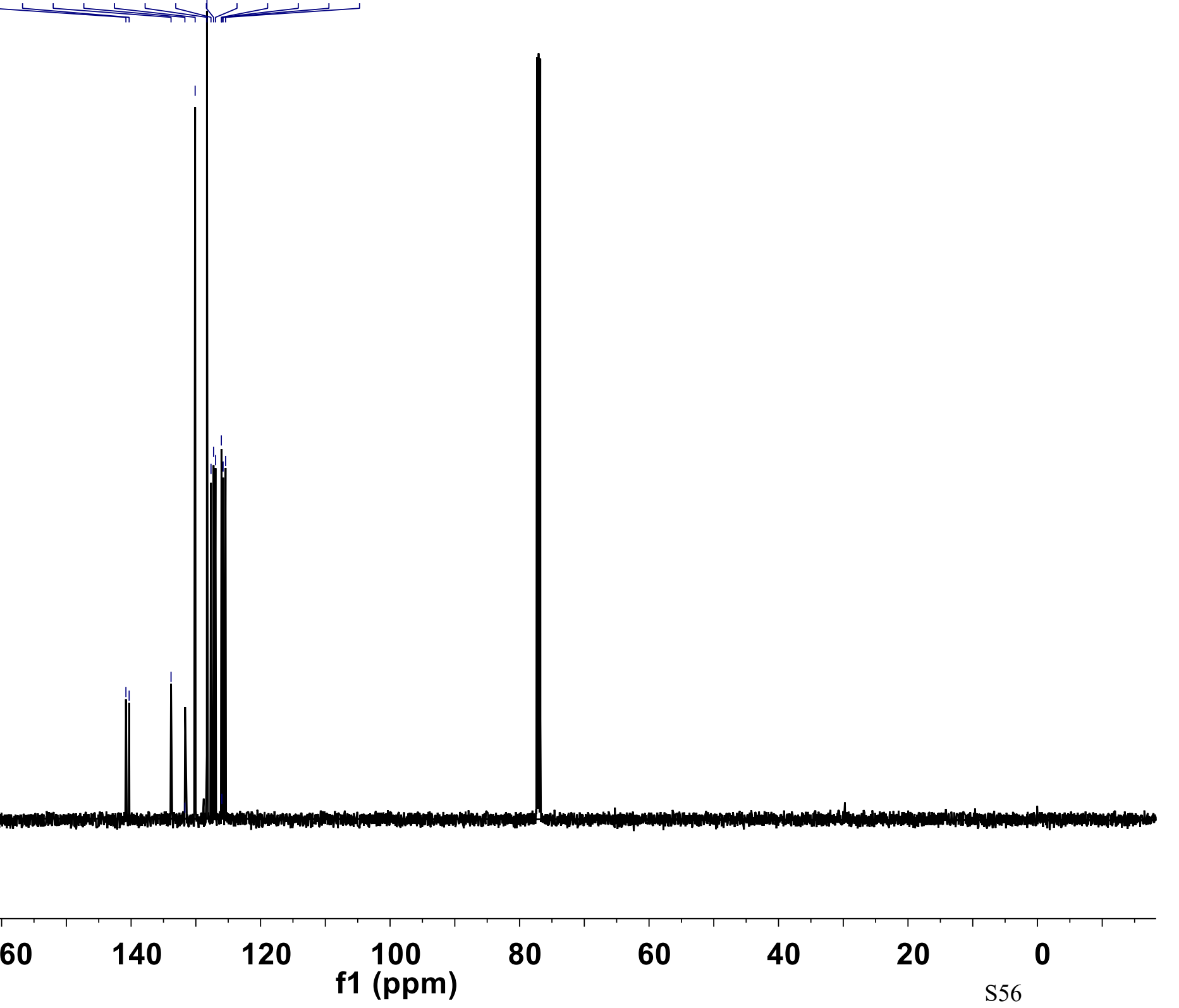




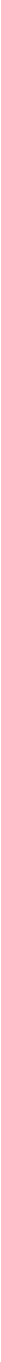


$7,1 \mathrm{H}$

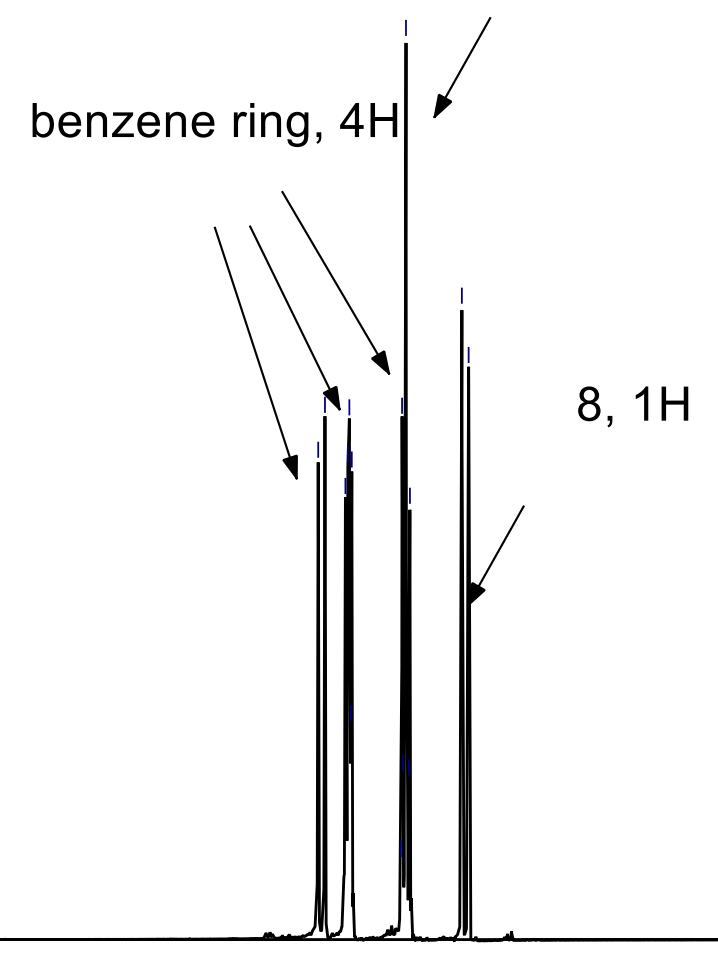

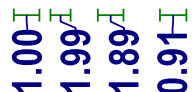

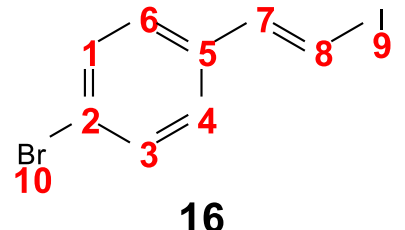

16

\section{0}

7.0

6.0

5.0

4.0

3.0

2.0

1.0

0.0

$-1.0$ 


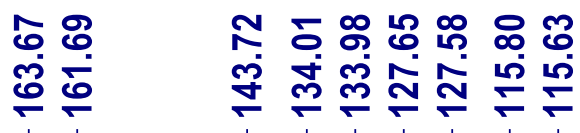

i

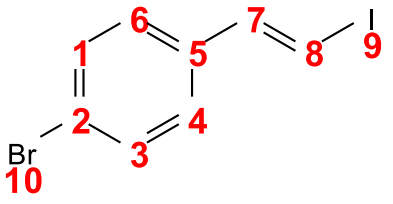




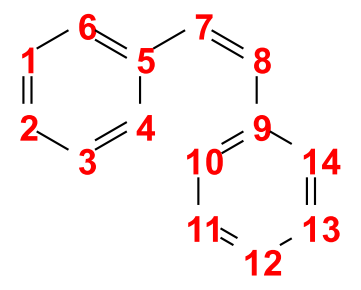

benzene ring, $10 \mathrm{H}$

$15 a$

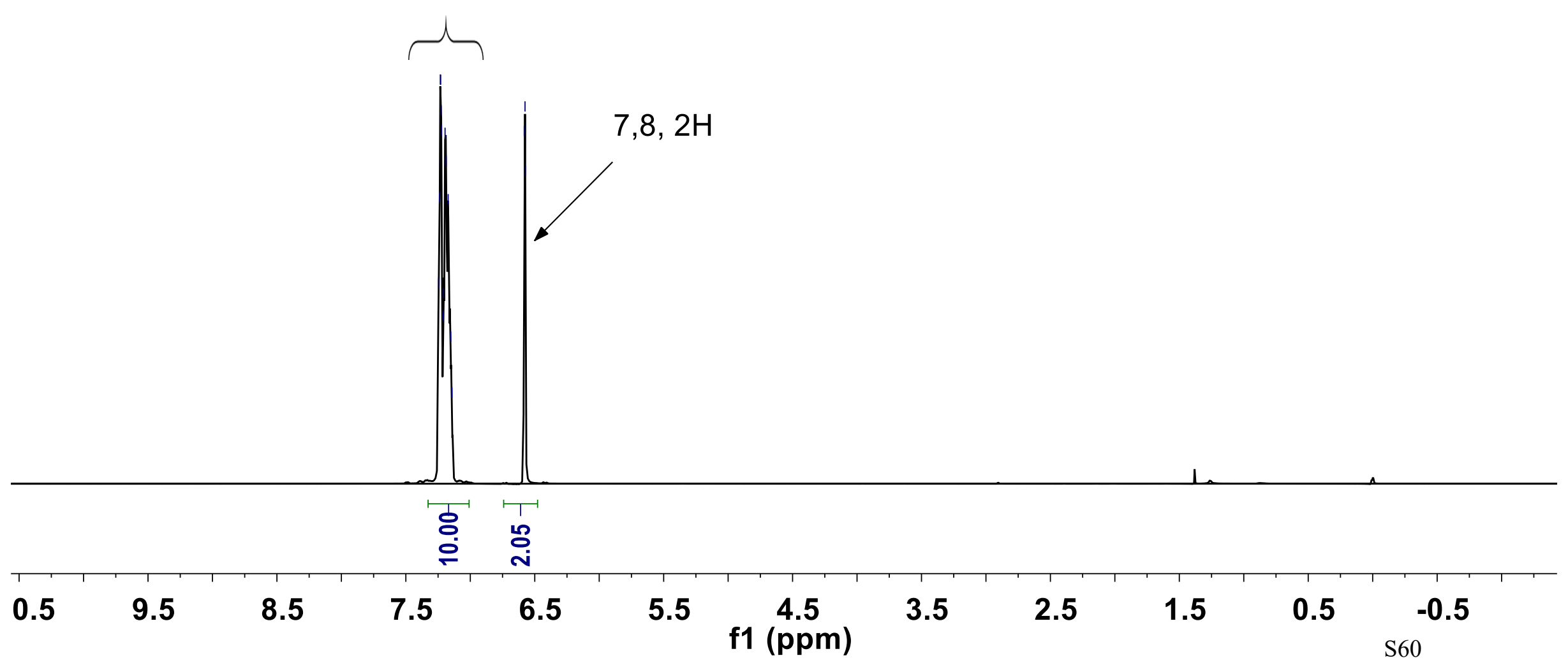


ำ 웅 ஜ

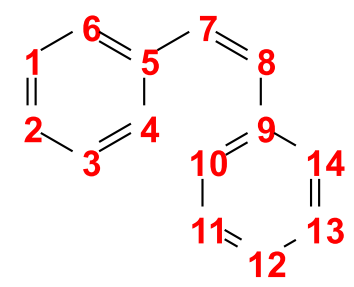

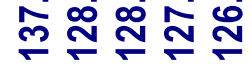

$15 a$

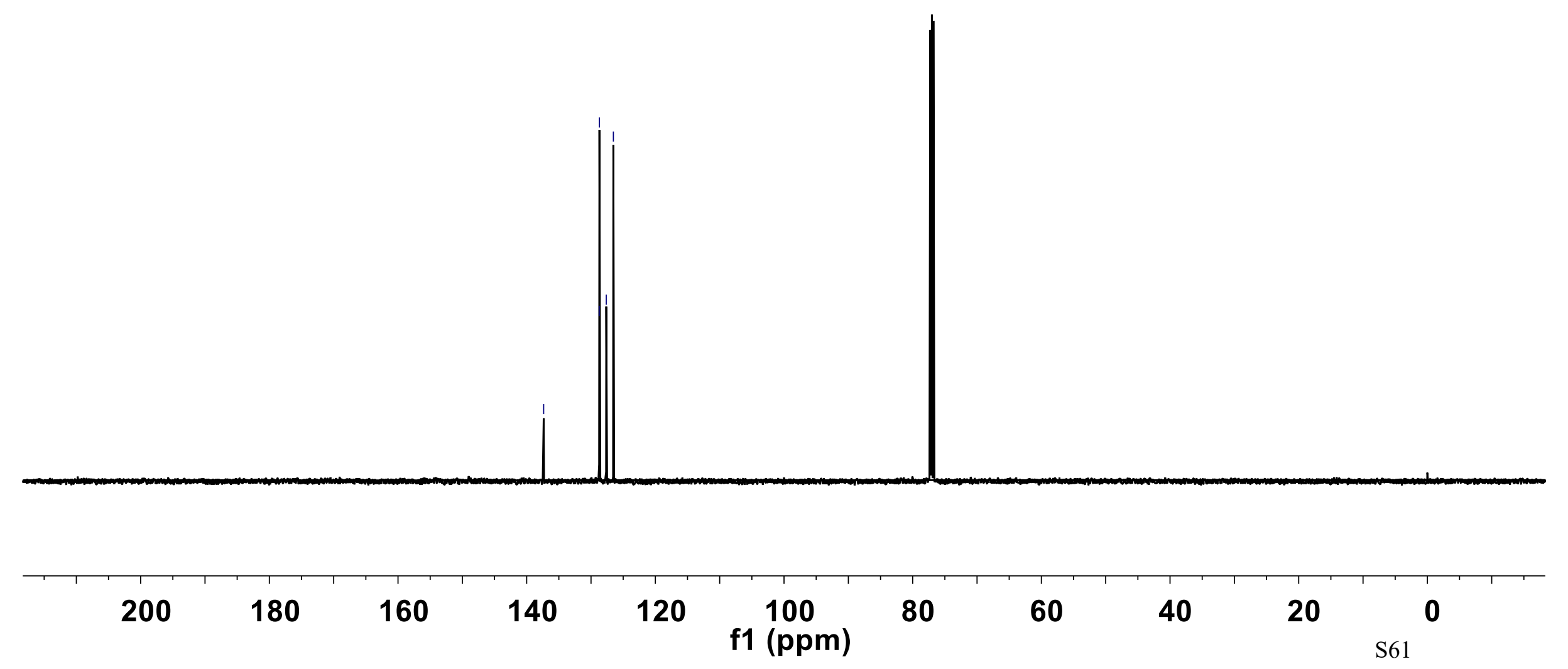




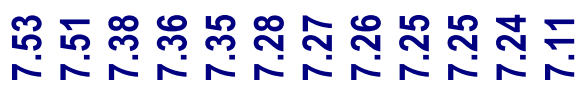

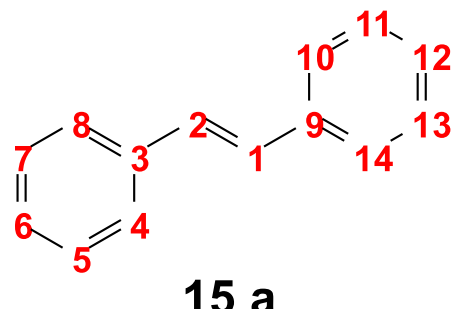

15 a

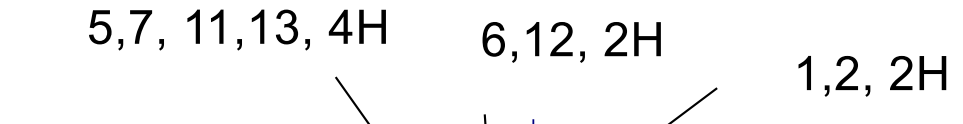

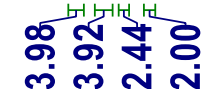

7.5

6.5

5.5
$\mathrm{f} 1(\mathrm{ppm})$

3.5

2.5

1.5

0.5 
ำ

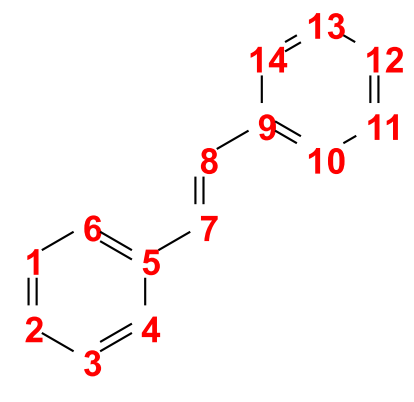

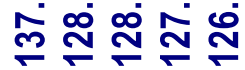

$15 a$

\begin{tabular}{|c|c|c|c|c|c|c|c|c|c|c|}
\hline 200 & 180 & 160 & 140 & 120 & $\begin{array}{c}100 \\
\mathrm{f} 1 \text { (ppm) }\end{array}$ & 80 & 60 & 40 & 20 & 3 \\
\hline
\end{tabular}




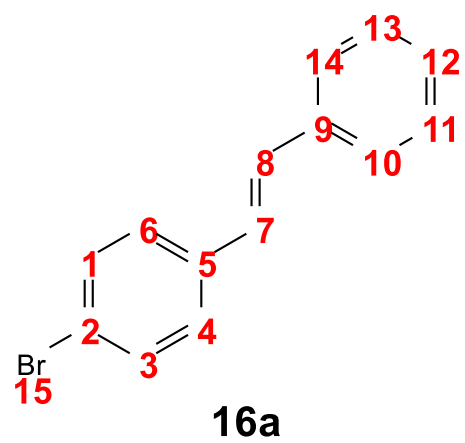

benzene ring, $9 \mathrm{H}$

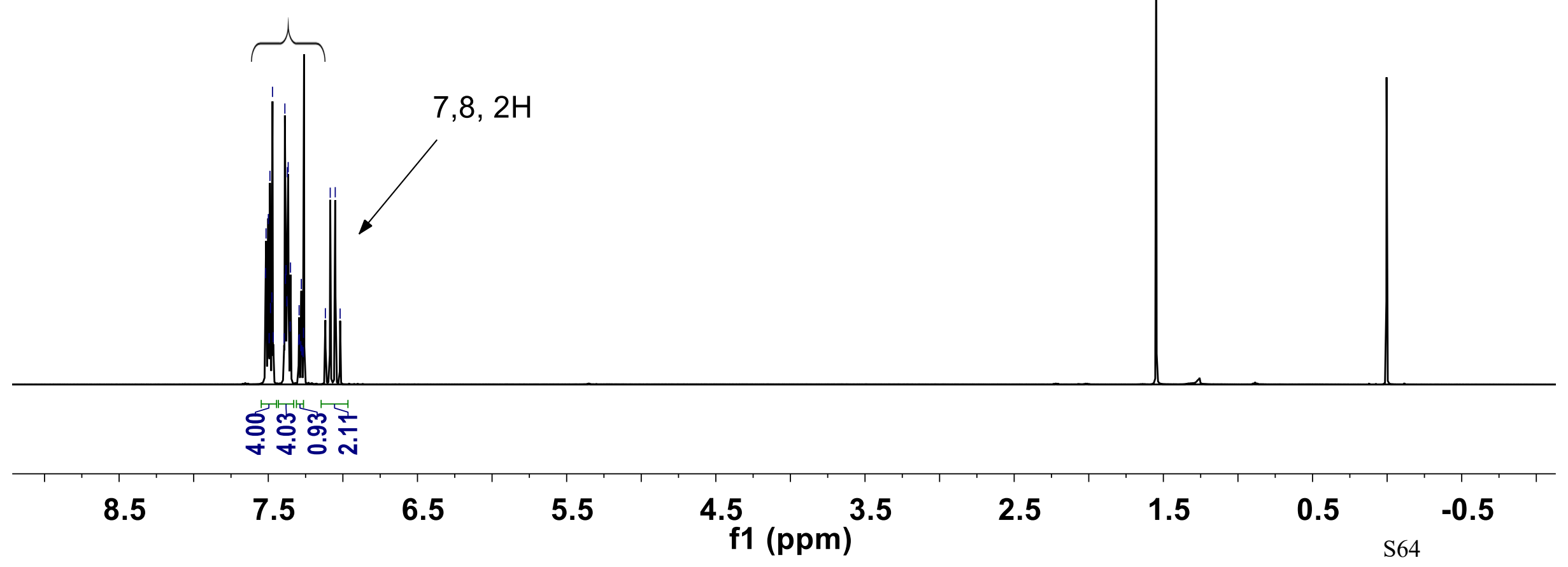



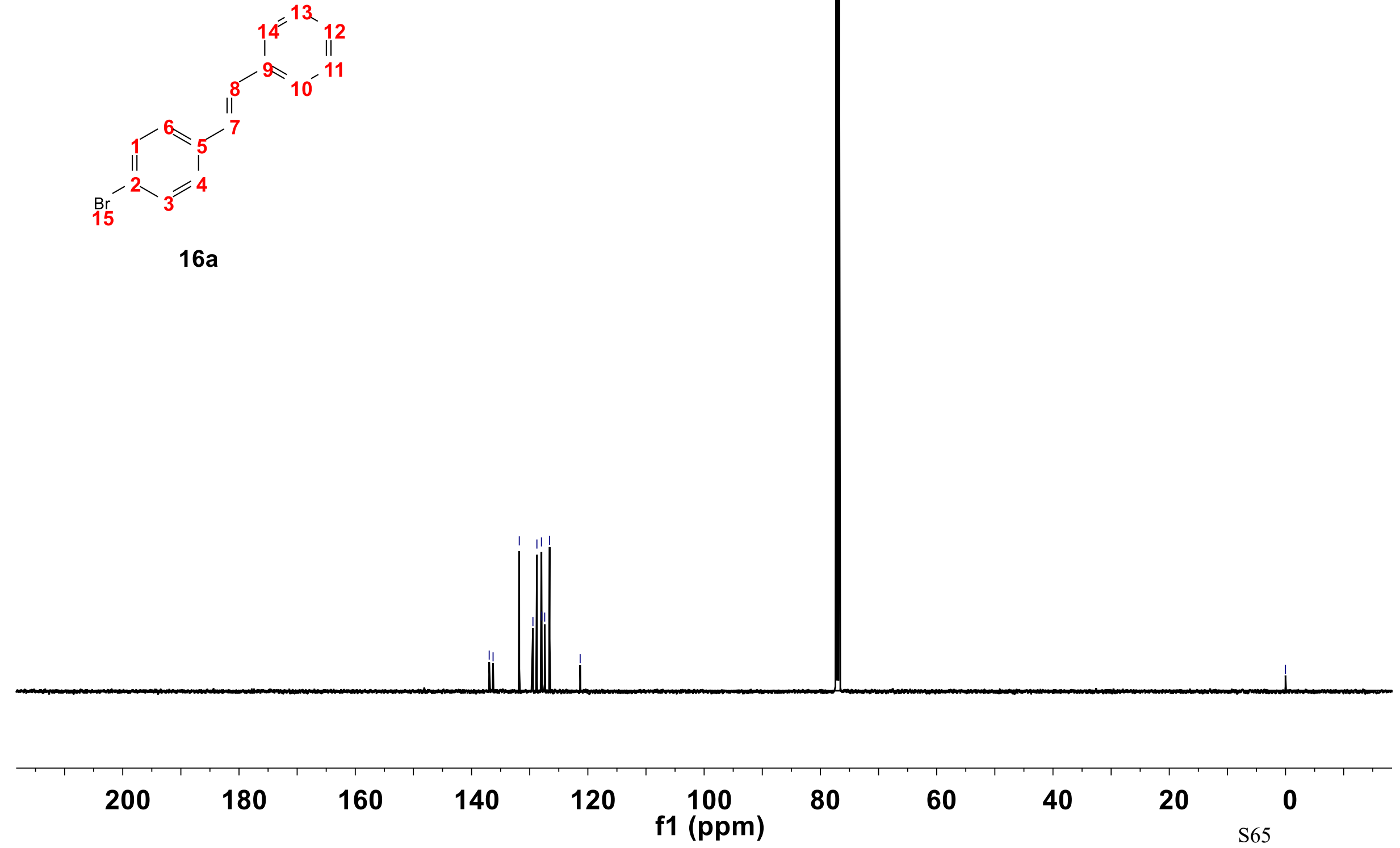
ポ

benezene ring, $9 \mathrm{H}$

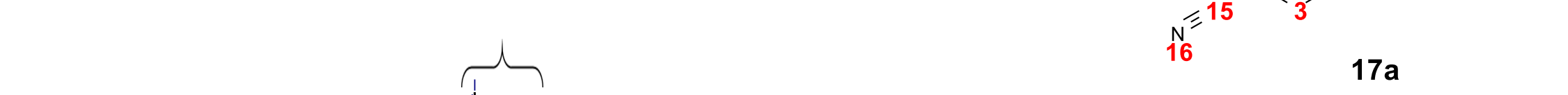

$\mathrm{CHCl} 3$ impurity

잉

\begin{tabular}{|c|c|c|c|c|c|c|c|c|}
\hline 10.5 & 9.5 & 8.5 & 7.5 & 6.5 & $\begin{array}{l}5.5 \\
\mathrm{f1}(\mathrm{ppm})\end{array}$ & 3.5 & 2.5 & 1.5 \\
\hline
\end{tabular}




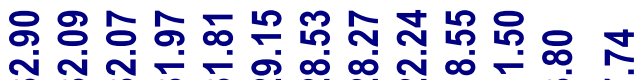

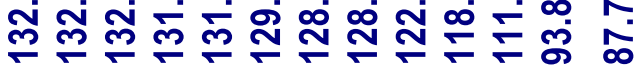

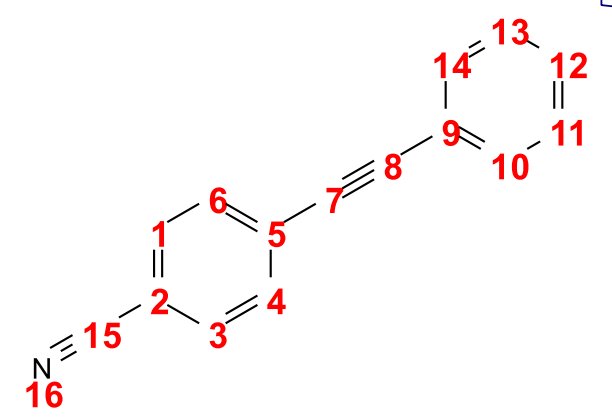

$17 a$

\begin{tabular}{|c|c|c|c|c|c|c|c|c|c|c|}
\hline 200 & 180 & 160 & 140 & 120 & $\begin{array}{l}100 \\
\mathrm{f} 1 \text { (ppm) }\end{array}$ & 80 & 60 & 40 & 20 & 57 \\
\hline
\end{tabular}




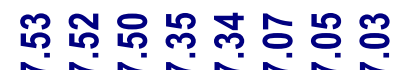

NNNNNN

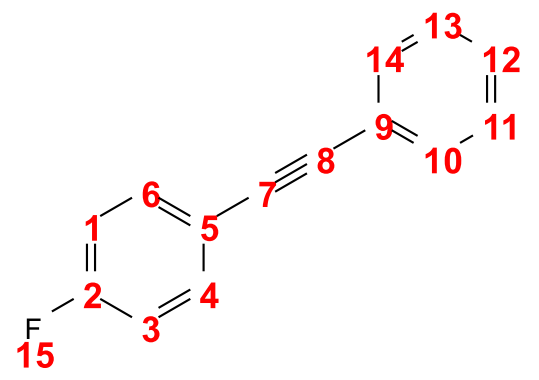

$18 a$

benzene ring , $9 \mathrm{H}$

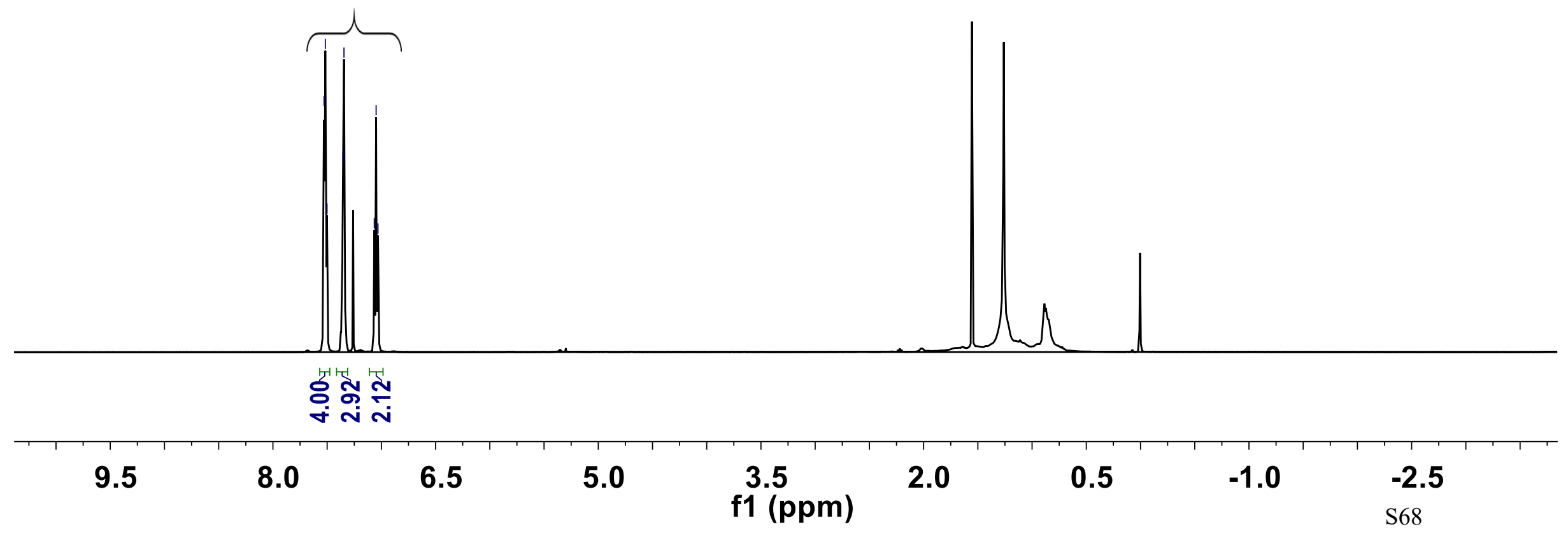




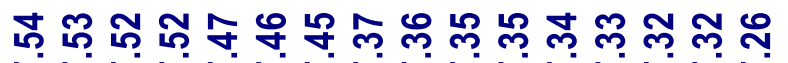

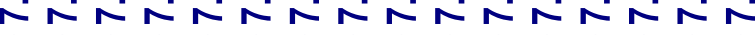

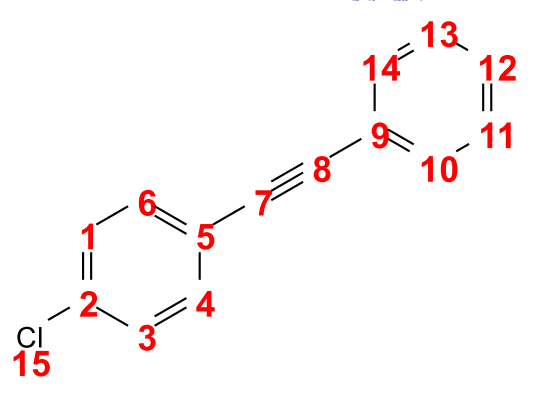

$19 a$

benzene ring, $9 \mathrm{H}$

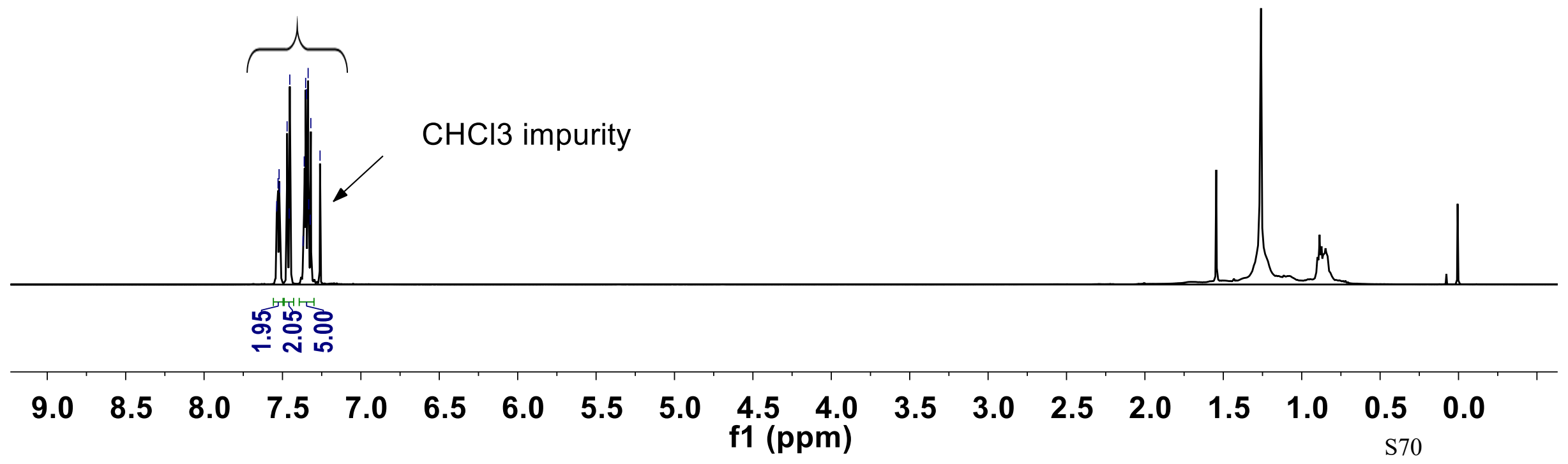


benzene ring, $5 \mathrm{H}$

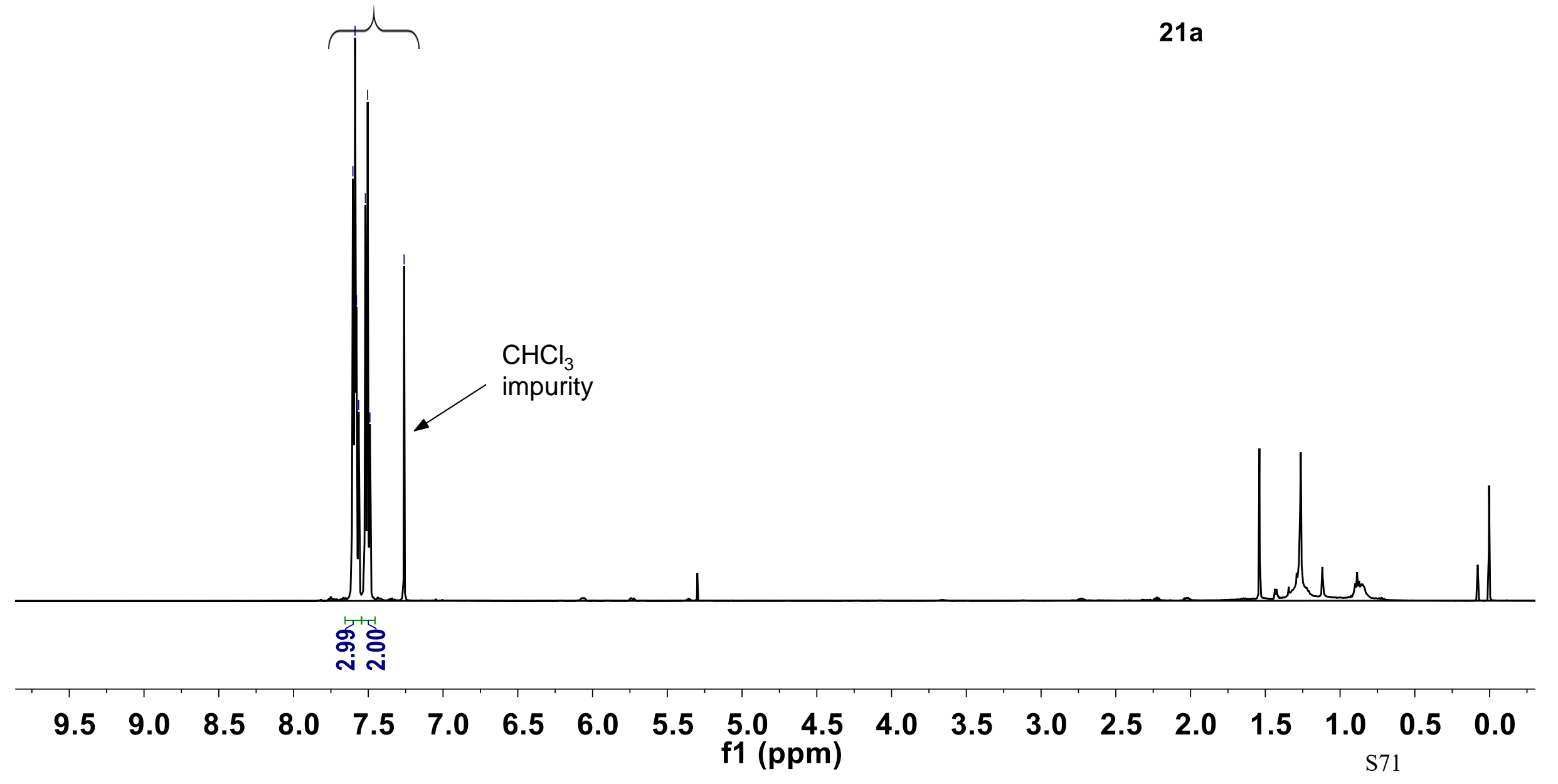




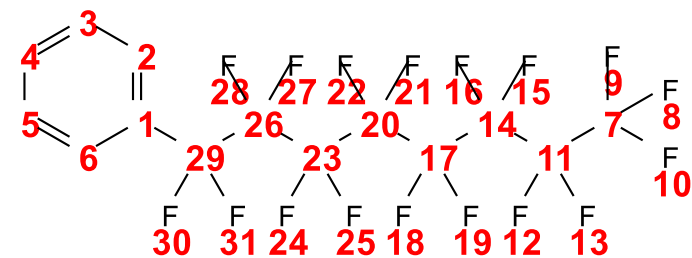

$21 a$

\begin{tabular}{|c|c|c|c|c|c|c|c|c|c|c|}
\hline 200 & 180 & 160 & 140 & 120 & $\begin{array}{c}100 \\
\mathrm{f} 1 \text { (ppm) }\end{array}$ & 80 & 60 & 40 & 20 & $2^{0}$ \\
\hline
\end{tabular}


$\stackrel{0}{\infty} \infty$

œ

$+$

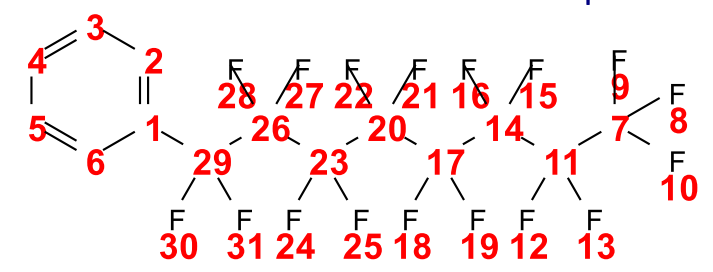

$\begin{array}{cccccccc}F & F & F & F & F & F & F & F \\ 30 & 3124 & 25 & 18 & 19 & 12 & 13\end{array}$

$$
8,9,10,3 F
$$

$15,16,2 \mathrm{~F}$

$10 \mathrm{~F}$

$$
30,31,2 \mathrm{~F}
$$

\begin{tabular}{|c|c|c|c|c|c|c|c|c|c|c|c|c|c|c|}
\hline & & & $\underset{j}{1}$ & & & & & & $\begin{array}{l}1 \\
\stackrel{\infty}{i}\end{array}$ & & $\stackrel{c}{e}$ & $\stackrel{\square}{\stackrel{T}{\leftarrow}}$ & & \\
\hline-65 & -70 & -75 & -80 & -85 & -90 & -95 & $\begin{array}{c}-100 \\
\mathrm{f} 1 \text { (ppm) }\end{array}$ & -105 & -110 & -115 & -120 & -125 & $\begin{array}{r}-130 \\
S 73\end{array}$ & -135 \\
\hline
\end{tabular}




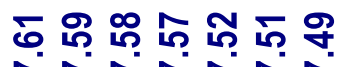 \\ N $N$ N}

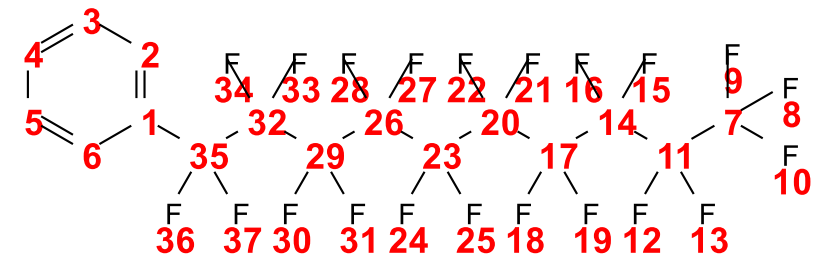

\section{$22 a$}

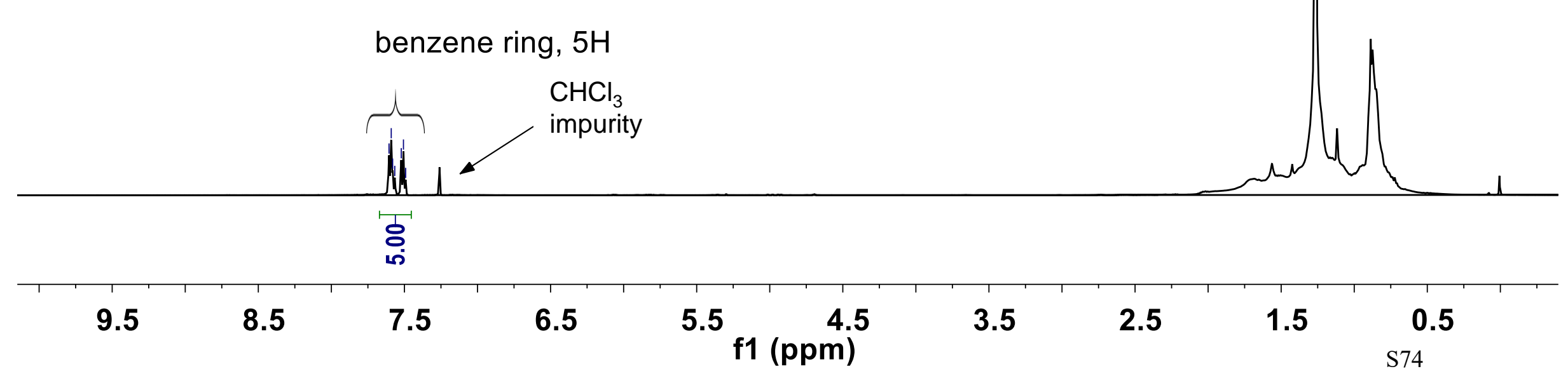




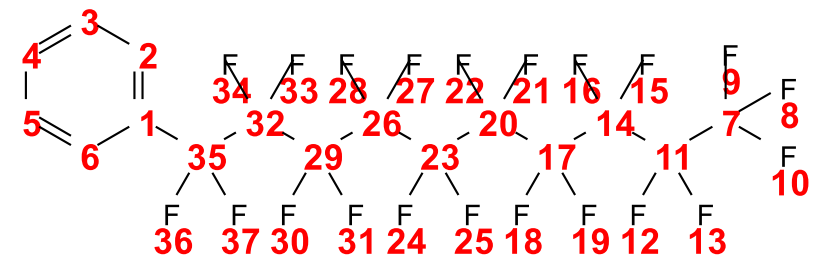

\section{$22 a$}

$$
8,9,10,3 \mathrm{~F}
$$$$
36,37,14 \mathrm{~F}
$$

$12,13,2 \mathrm{~F}$

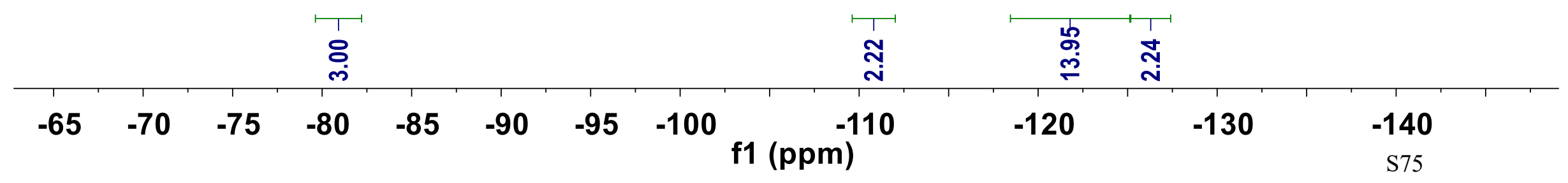


怘

1
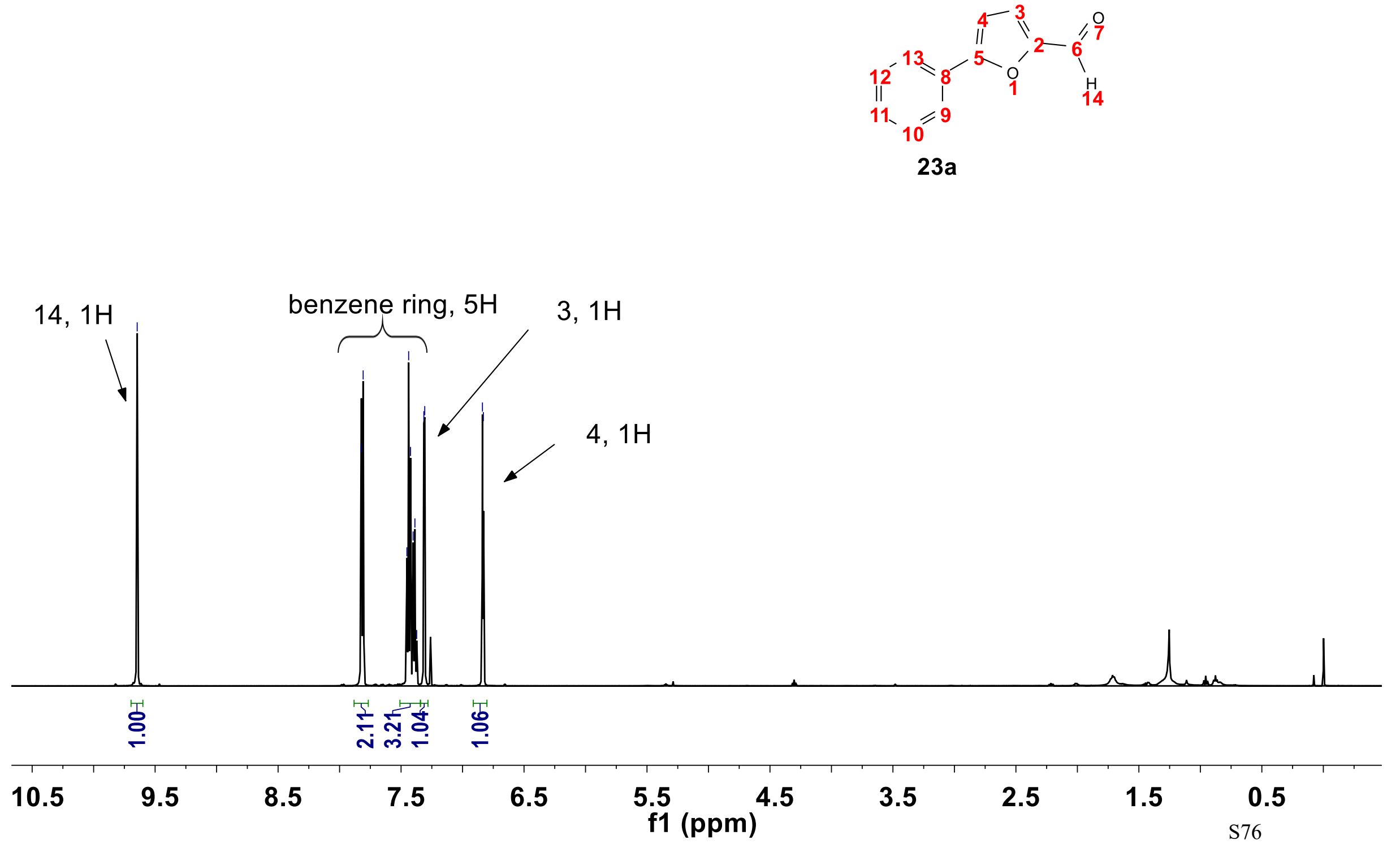


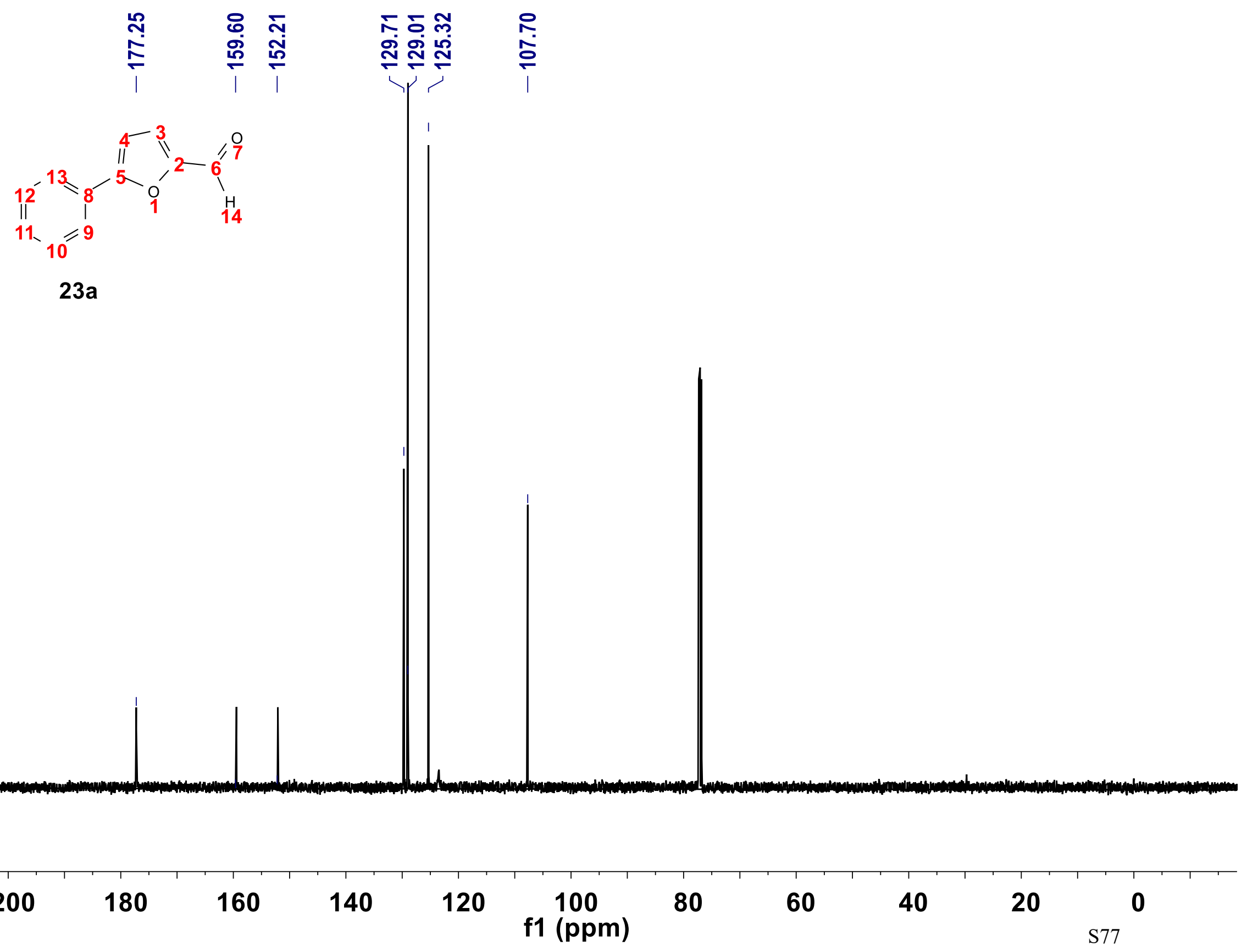




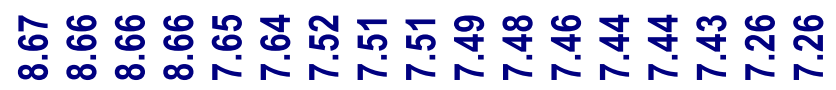
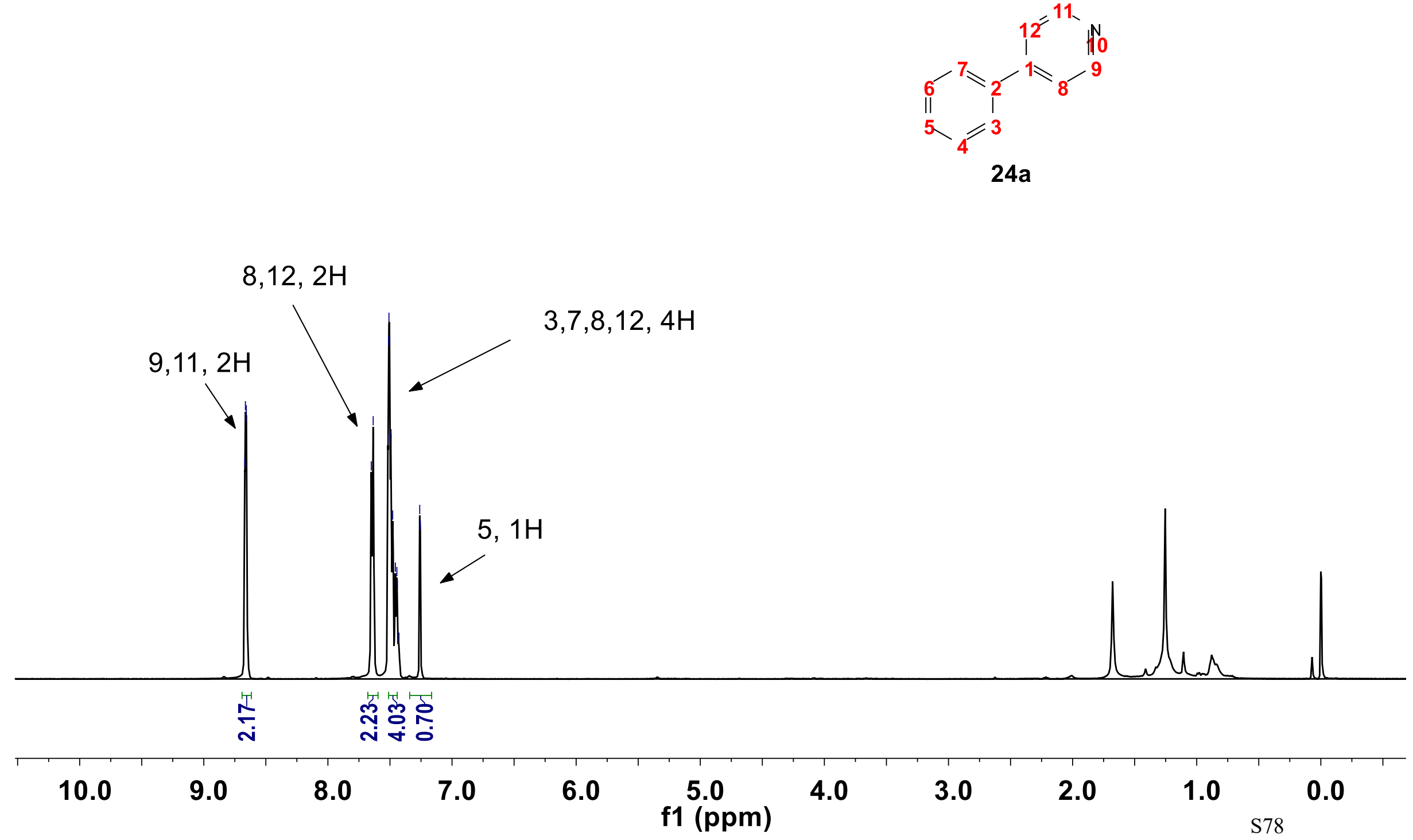


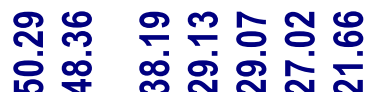

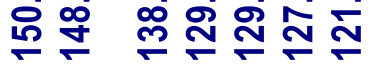

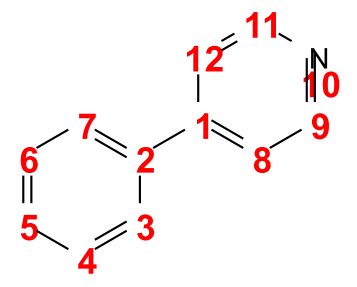

$24 a$

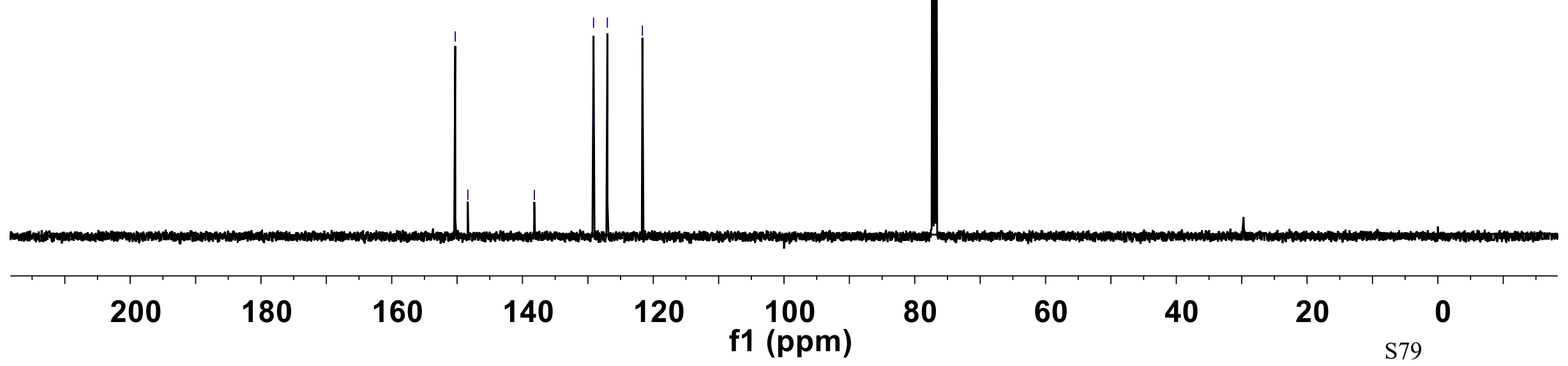




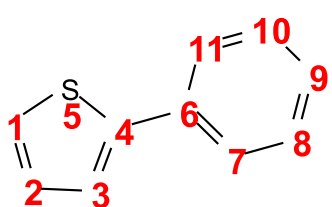

$25 a$

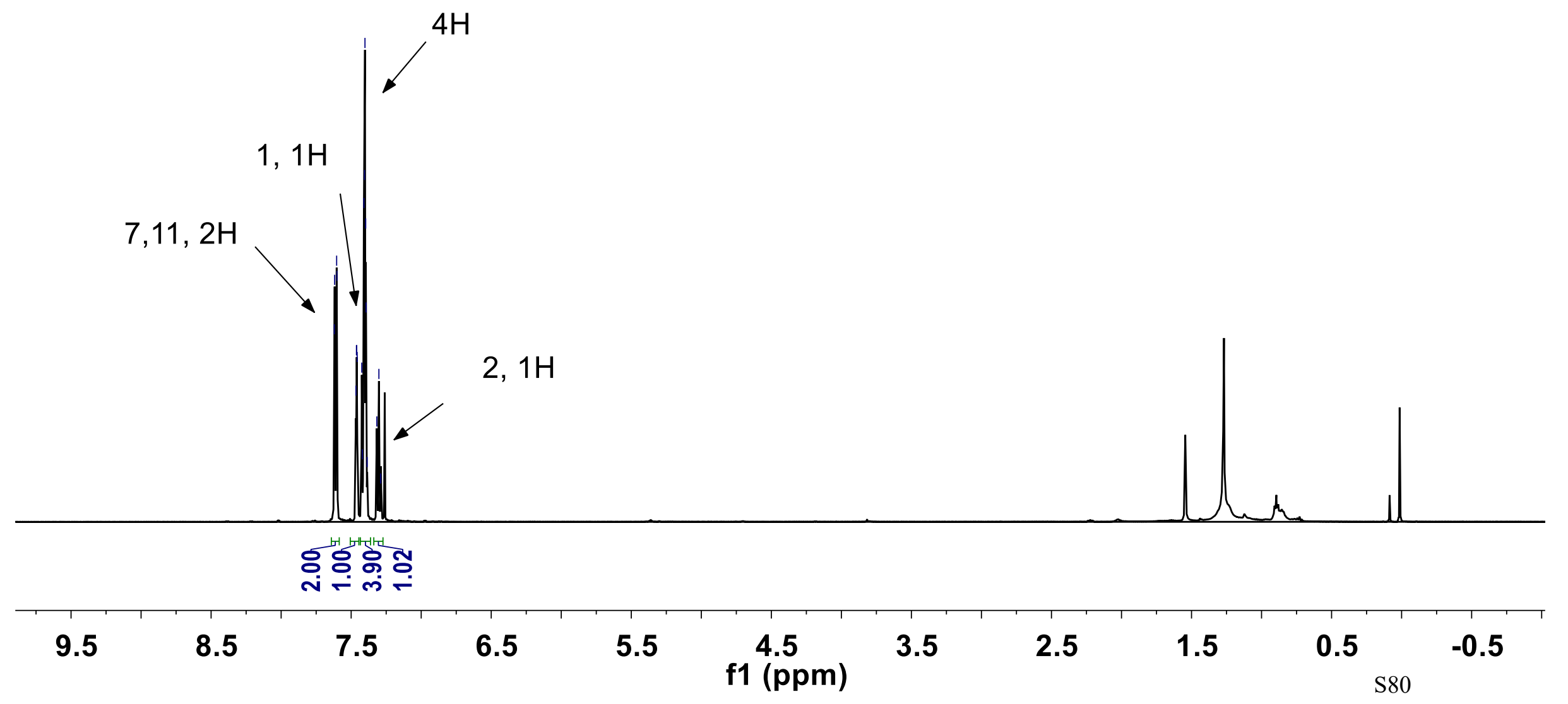




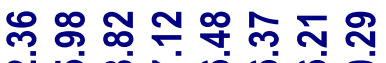

ฟั

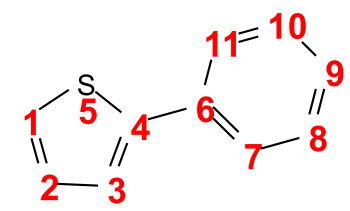

$25 a$

\begin{tabular}{|c|c|c|c|c|c|c|c|c|c|c|}
\hline 200 & 180 & 160 & 140 & 120 & $\begin{array}{c}100 \\
\mathrm{f} 1 \text { (ppm) }\end{array}$ & 80 & 60 & 40 & 20 & 0 \\
\hline
\end{tabular}




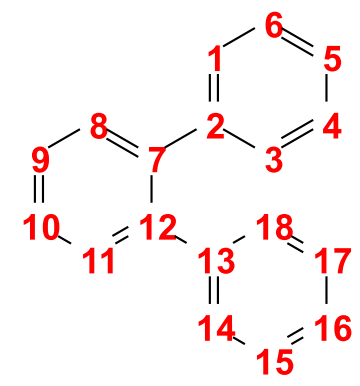

benzene ring, $14 \mathrm{H}$

$26 a$
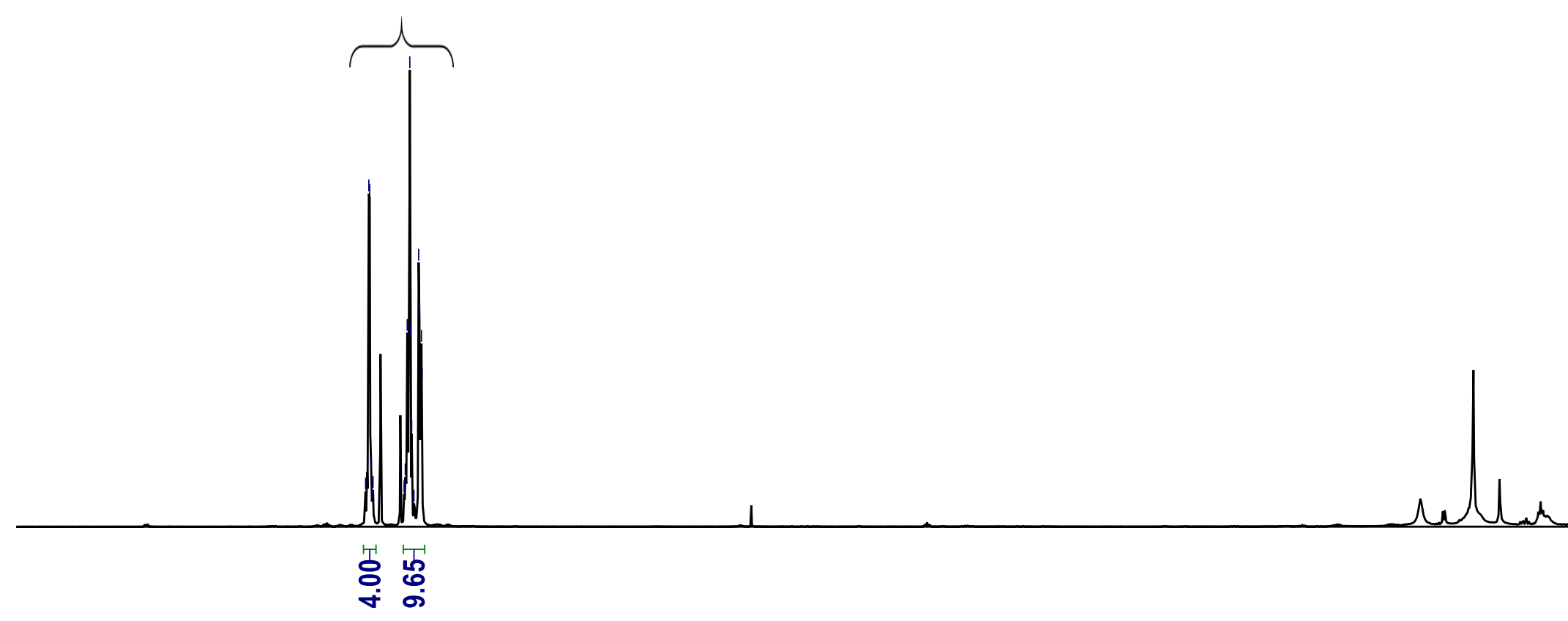

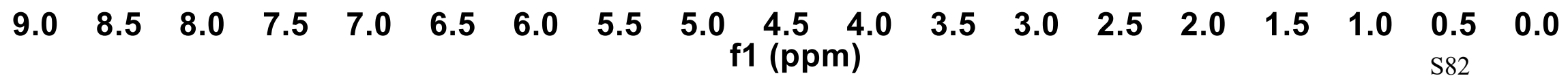


눙

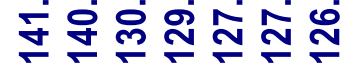

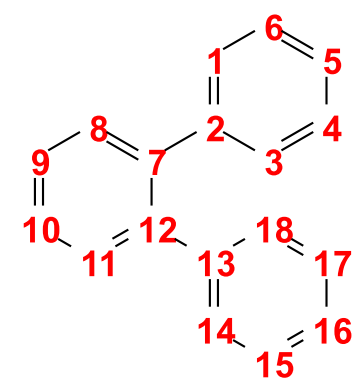

26a

\begin{tabular}{|c|c|c|c|c|c|c|c|c|c|c|}
\hline 200 & 180 & 160 & 140 & 120 & $\begin{array}{l}100 \\
\mathrm{f} 1 \text { (ppm) }\end{array}$ & 80 & 60 & 40 & 20 & 3 \\
\hline
\end{tabular}




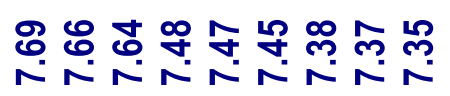

benzene ring, $14 \mathrm{H}$

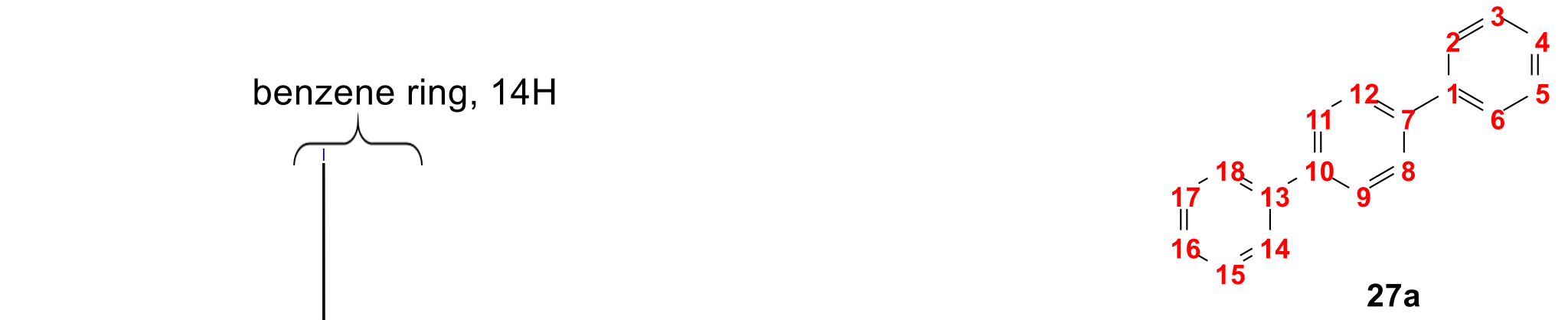

$\mathrm{CHCl}_{3}$

impurity
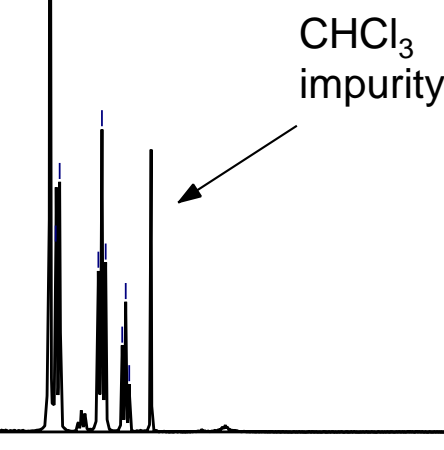

कृ \&

\begin{tabular}{|c|c|c|c|c|c|c|c|c|c|}
\hline 9.0 & 8.0 & 7.0 & 6.0 & 5.0 & $\begin{array}{r}4.0 \\
f 1 \text { (ppm) }\end{array}$ & 3.0 & 2.0 & 1.0 & 0.0 \\
\hline
\end{tabular}




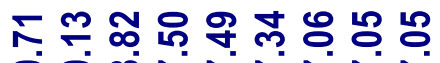

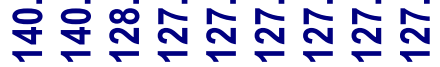
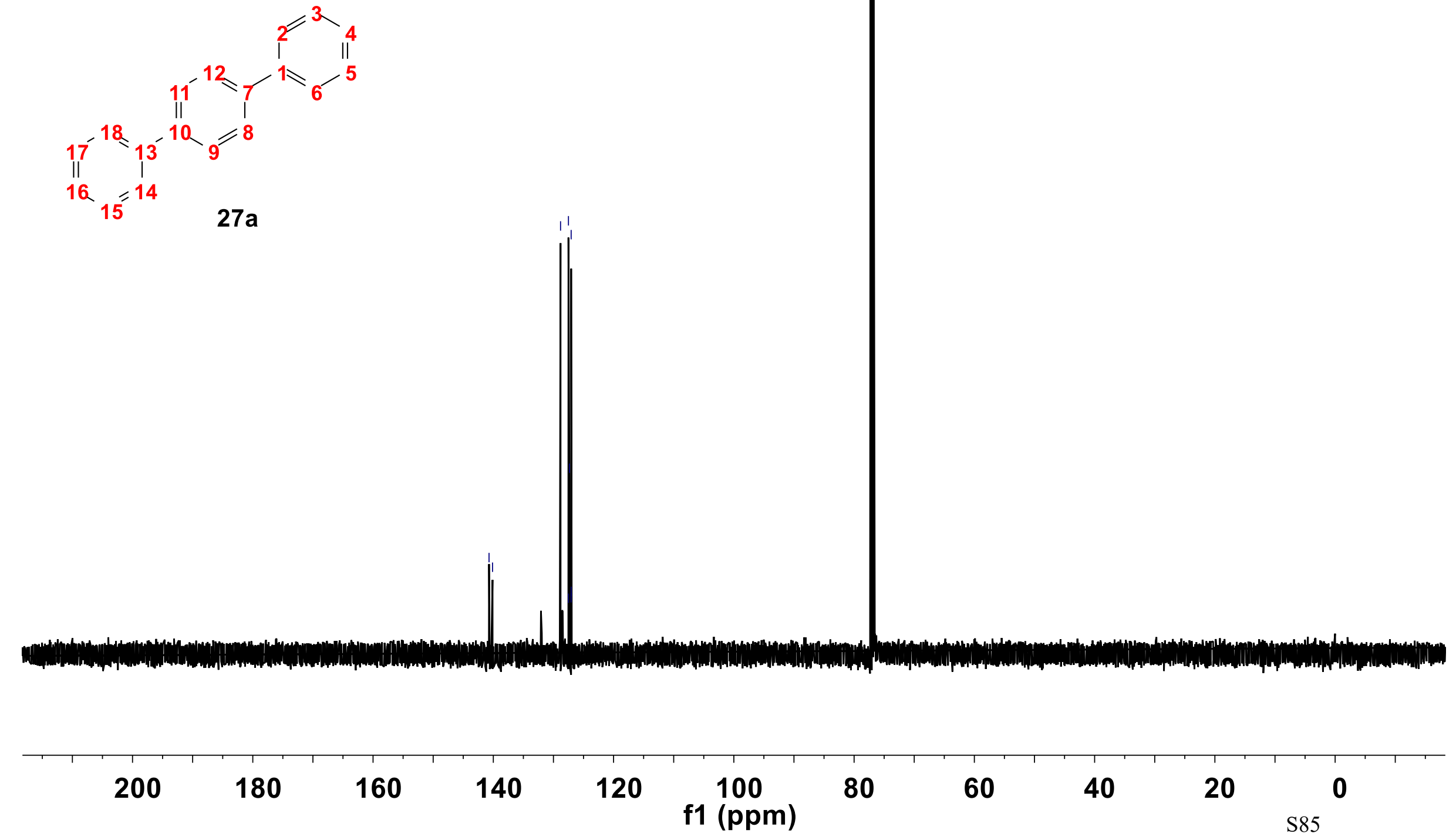

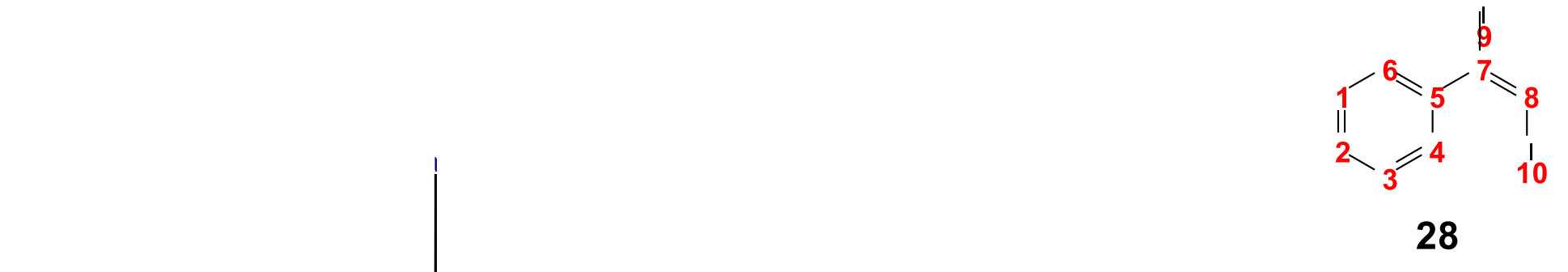

benzene ring, $5 \mathrm{H}$
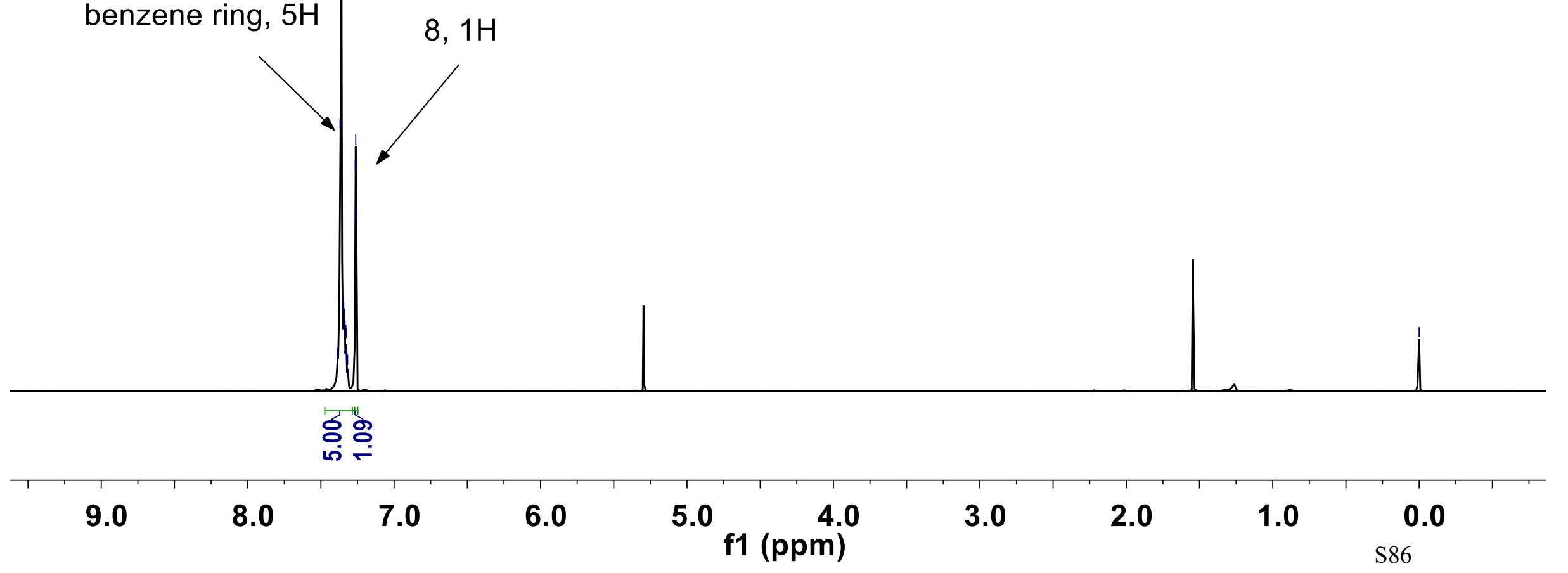


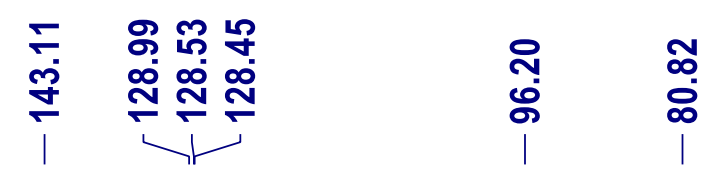

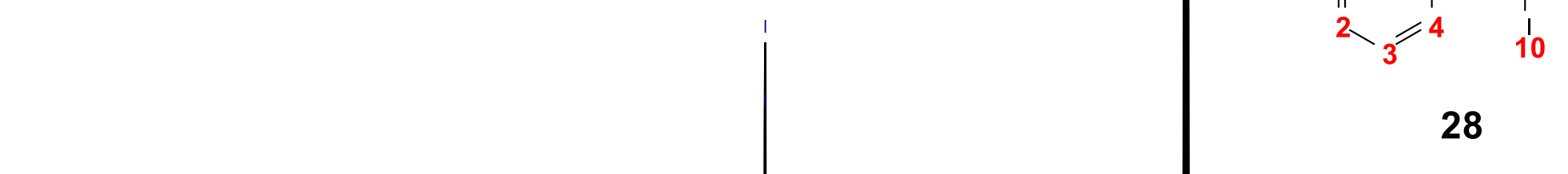

\begin{tabular}{|c|c|c|c|c|c|c|c|c|c|c|}
\hline $20 C$ & 180 & 160 & 140 & 120 & $\begin{array}{c}100 \\
\mathrm{f} 1 \text { (ppm) }\end{array}$ & 80 & 60 & 40 & 20 & ${ }_{37} \mathbf{0}$ \\
\hline
\end{tabular}




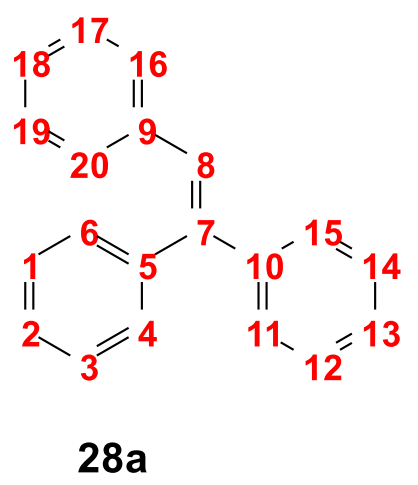

$16 \mathrm{H}$

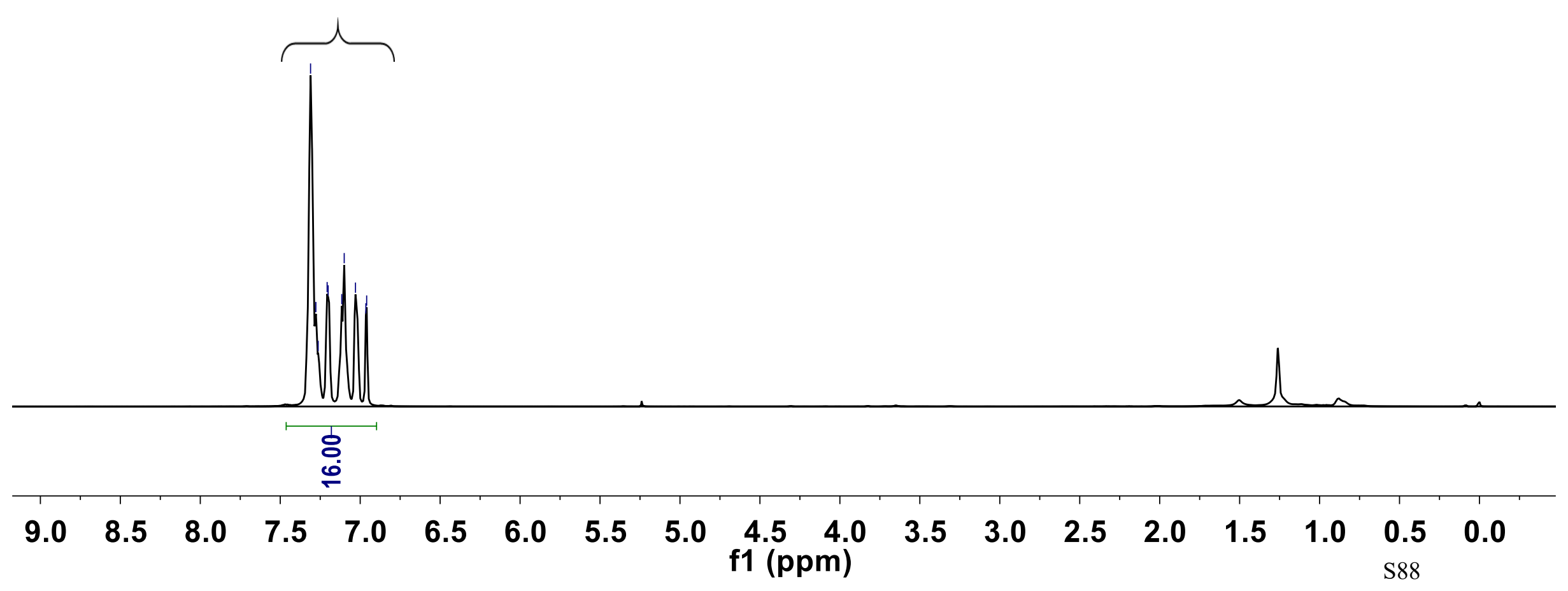




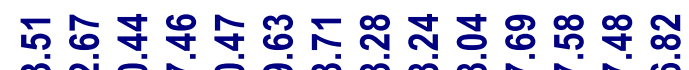

守 寸원

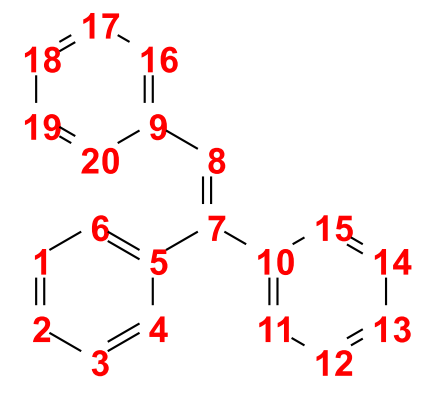

$28 a$

\begin{tabular}{|c|c|c|c|c|c|c|c|c|c|c|}
\hline 200 & 180 & 160 & 140 & 120 & $\begin{array}{l}100 \\
\mathrm{f} 1 \text { (ppm) }\end{array}$ & 80 & 60 & 40 & 20 & 0 \\
\hline
\end{tabular}




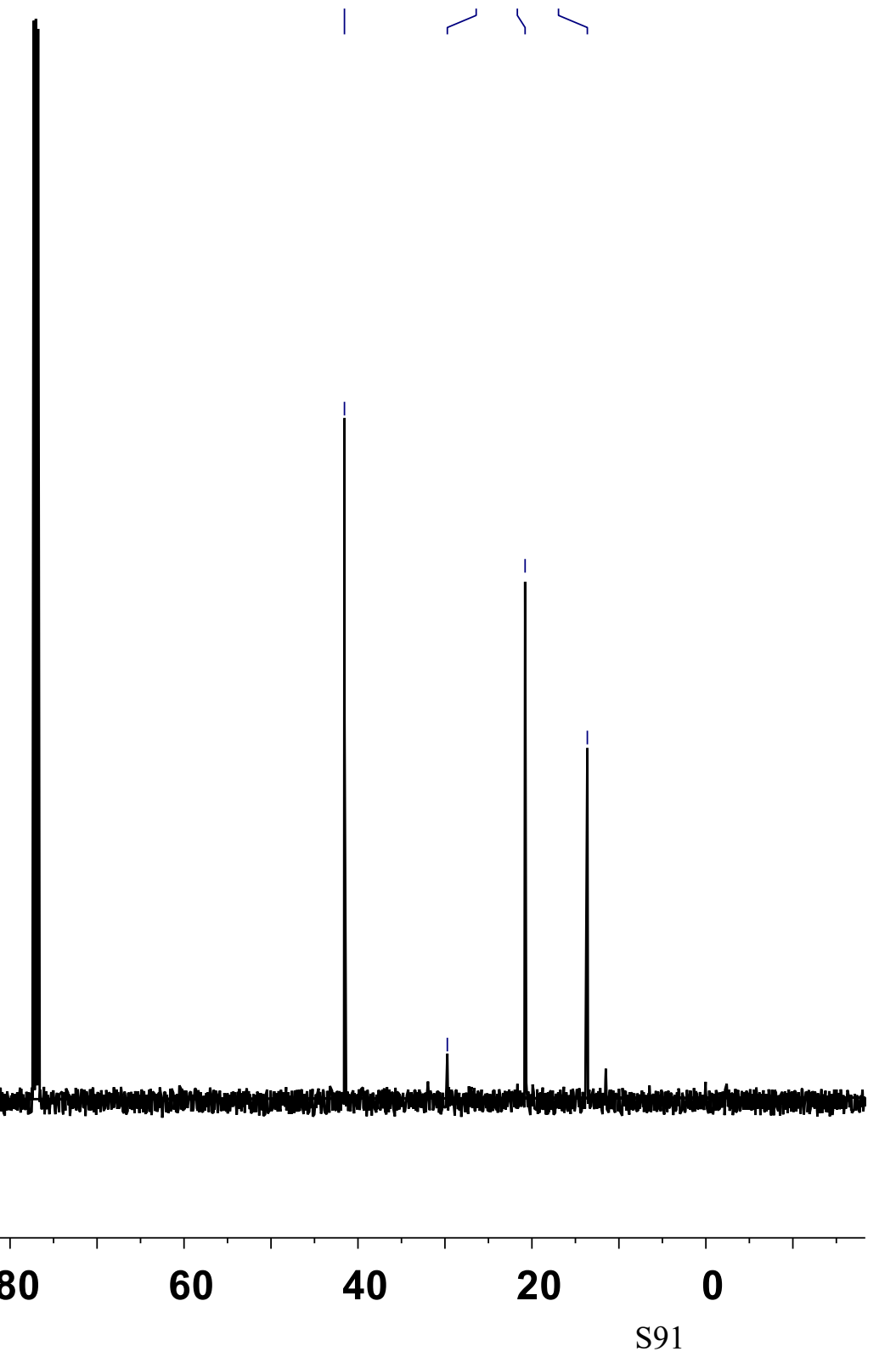




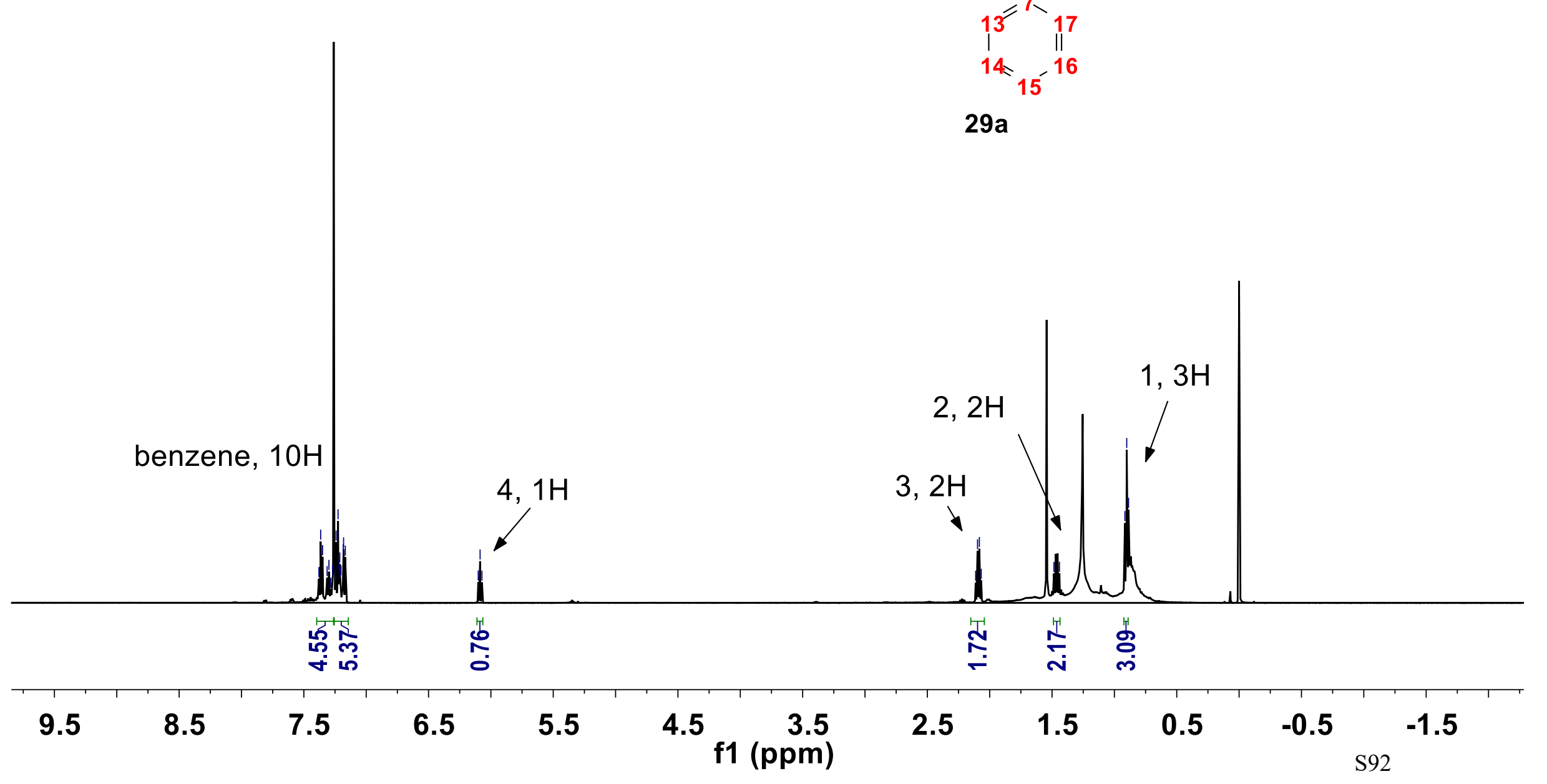




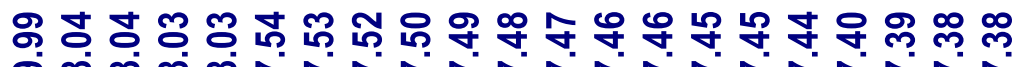

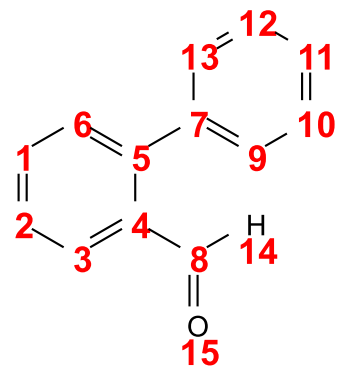

$30 a$

benzene ring, $7 \mathrm{H}$

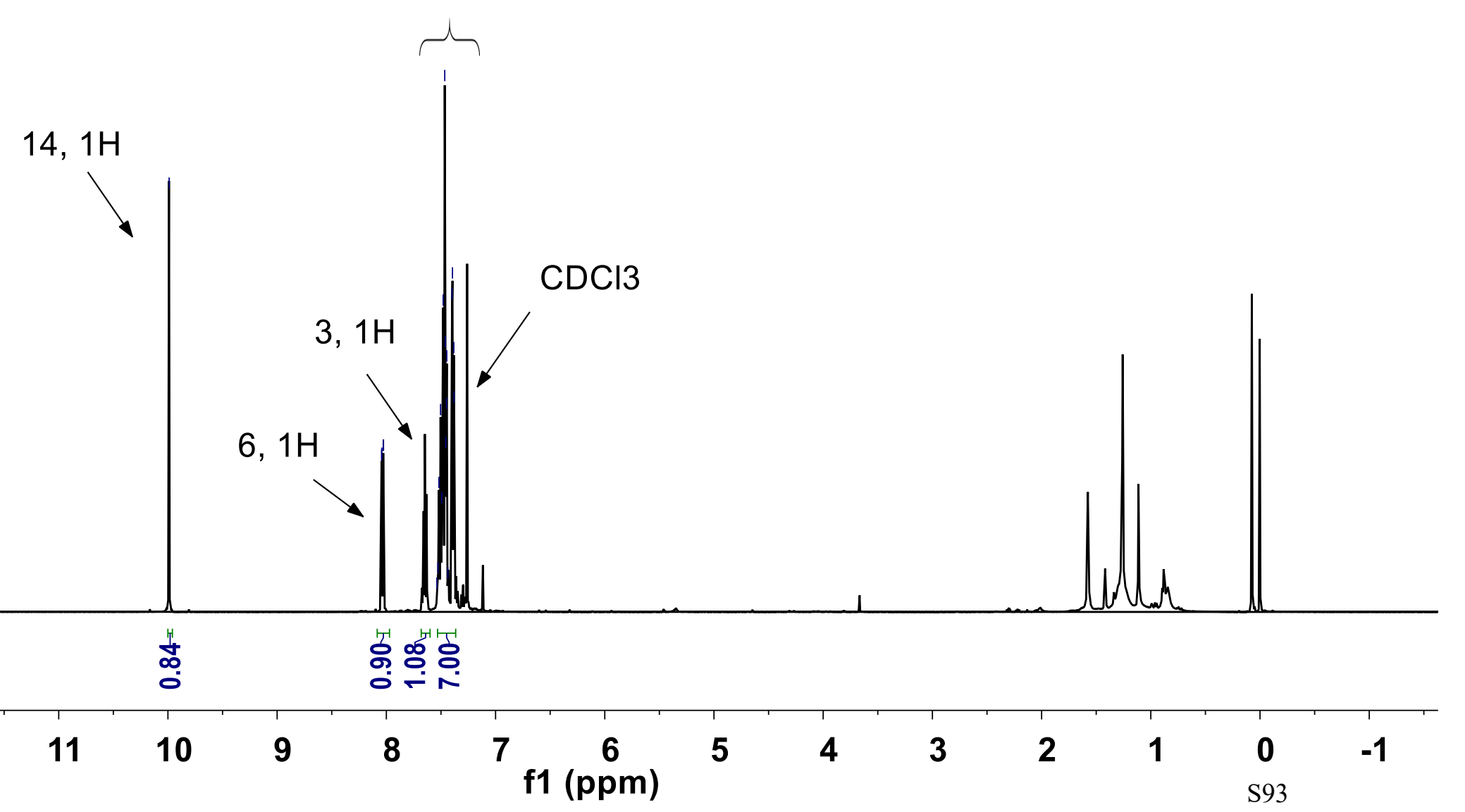



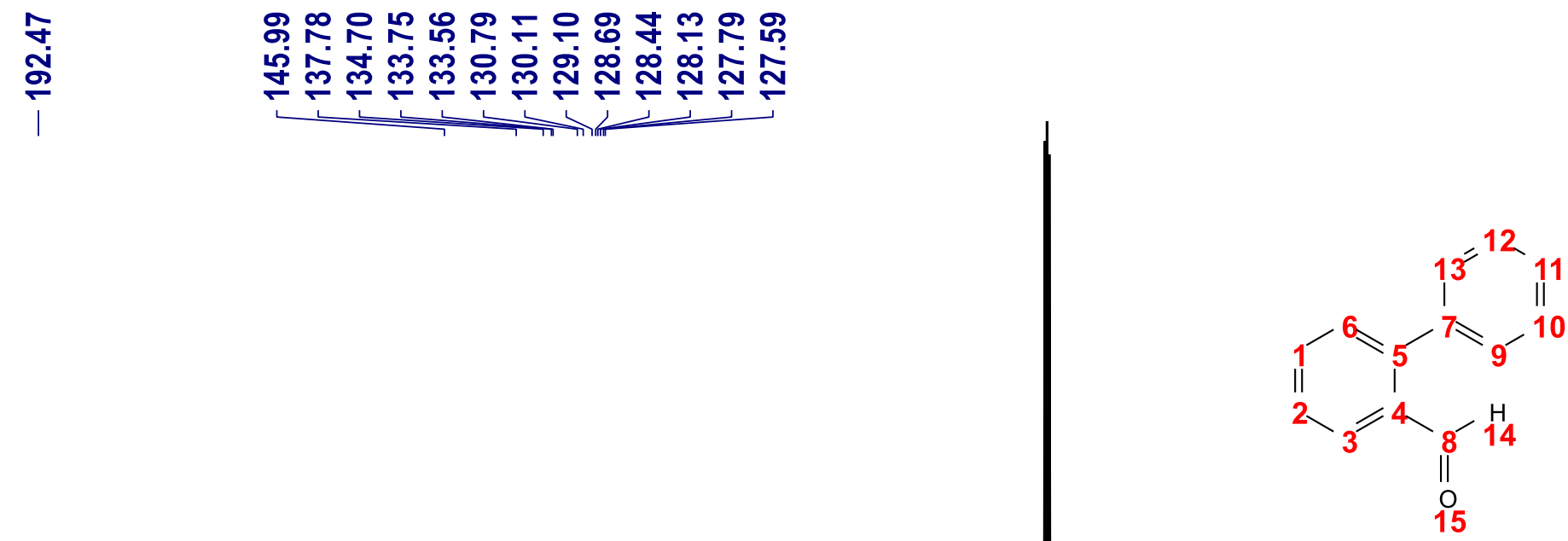

30 a 


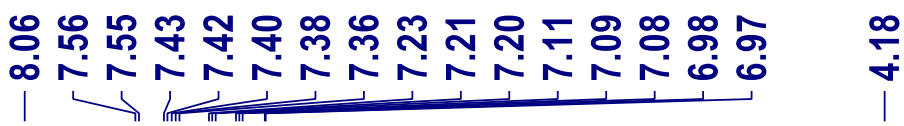

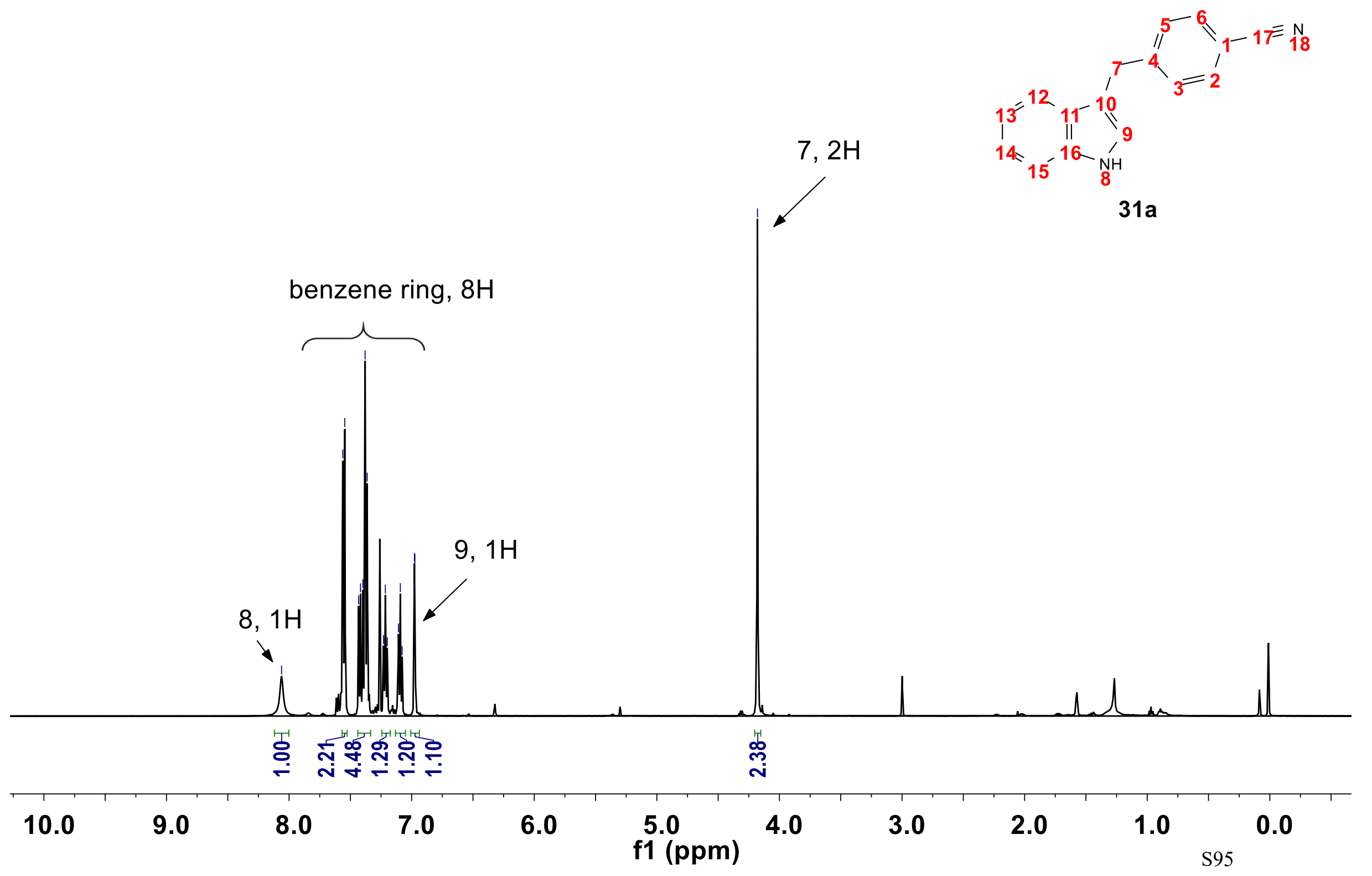


ชุ 矛商

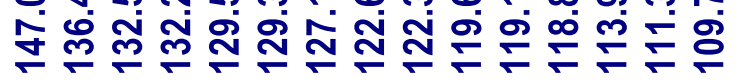
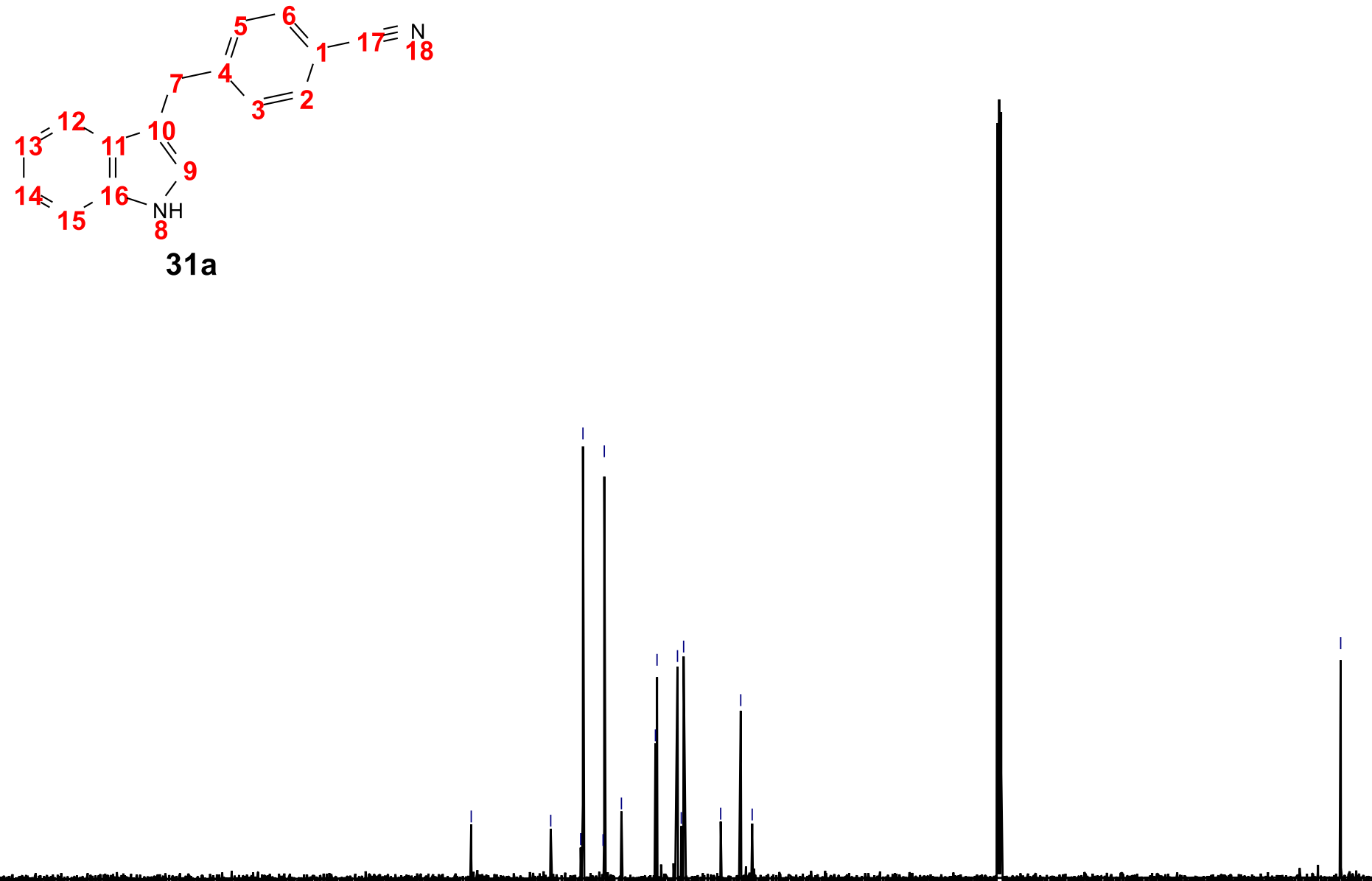

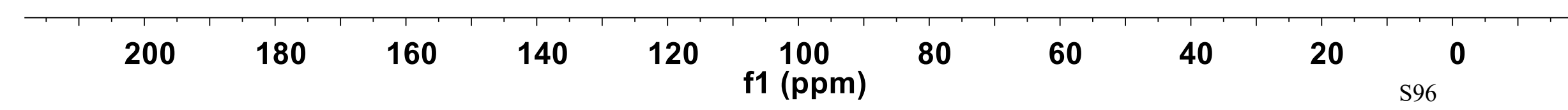


$18,3 \mathrm{H}$

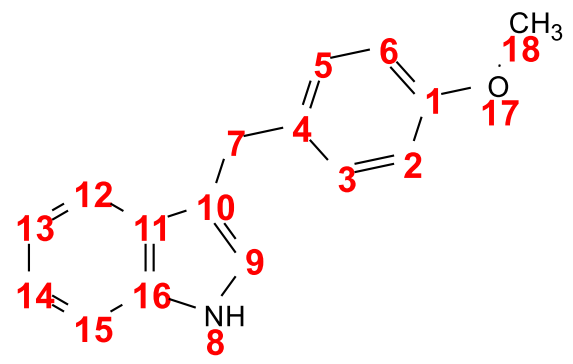

$32 a$

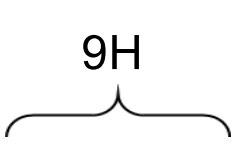

$8,1 \mathrm{H}$

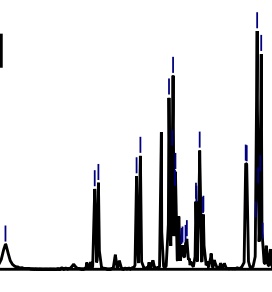

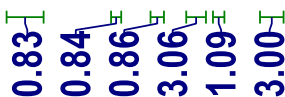

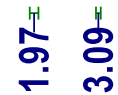

9.0

8.0

7.0

6.0

4.0

3.0

2.0

1.0

0.0

f1 (ppm) 
๓

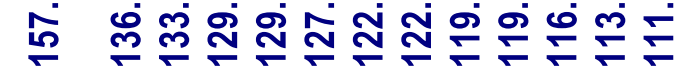

న

ถึ่

กิ

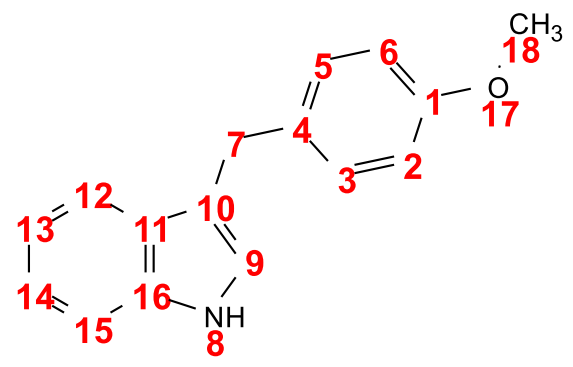

$32 a$

\begin{tabular}{|c|c|c|c|c|c|c|c|c|c|c|}
\hline 200 & 180 & 160 & 140 & 120 & $\begin{array}{c}100 \\
\mathrm{f} 1 \text { (ppm) }\end{array}$ & 80 & 60 & 40 & 20 & 8 \\
\hline
\end{tabular}




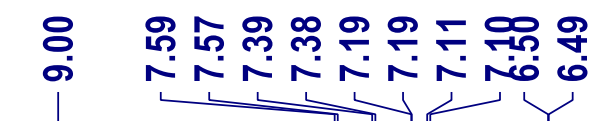

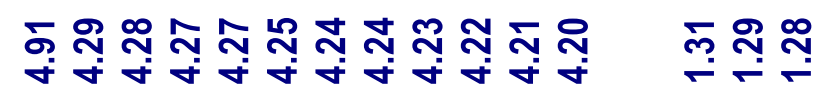

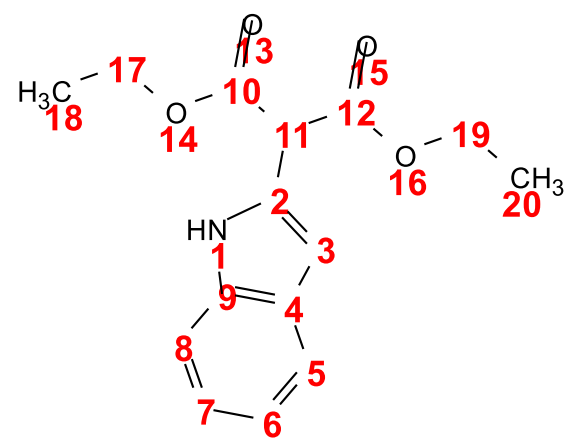

$33 a$

benzene ring, $4 \mathrm{H}$

$11,1 \mathrm{H} \quad 17,19,4 \mathrm{H}$

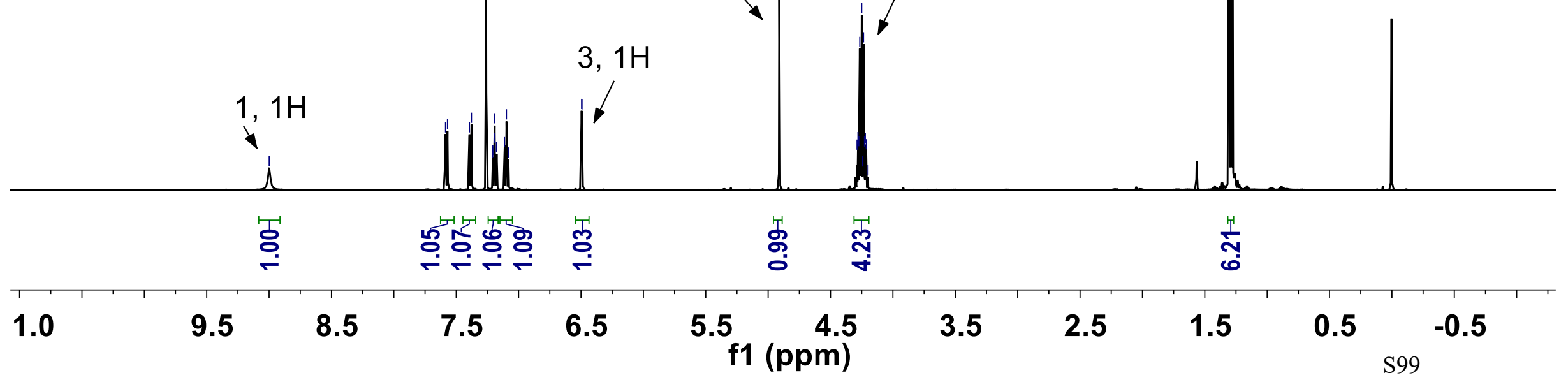




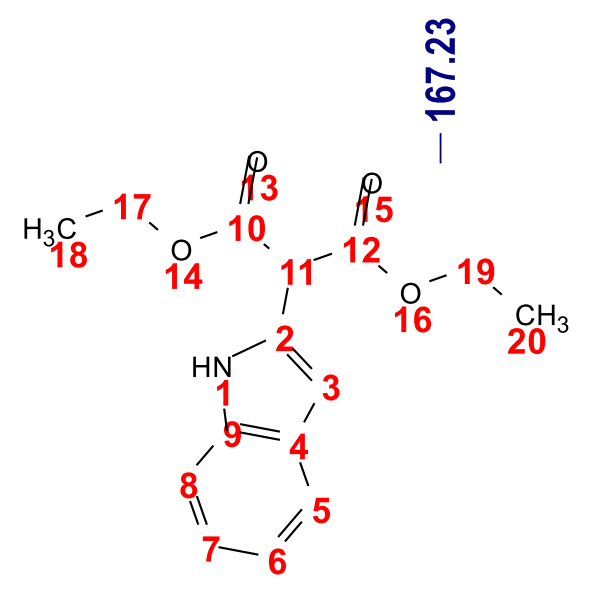

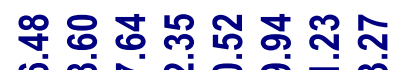

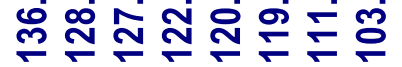

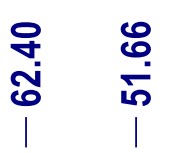

$\underset{\Im}{\mathfrak{Z}}$

$33 a$

\begin{tabular}{|c|c|c|c|c|c|c|c|c|c|c|}
\hline 200 & 180 & 160 & 140 & 120 & $\begin{array}{c}100 \\
\mathrm{f} 1 \text { (ppm) }\end{array}$ & 80 & 60 & 40 & 20 & 0 \\
\hline
\end{tabular}




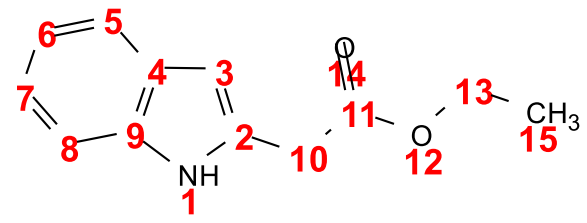

$35 a$

benzene ring, $4 \mathrm{H}$

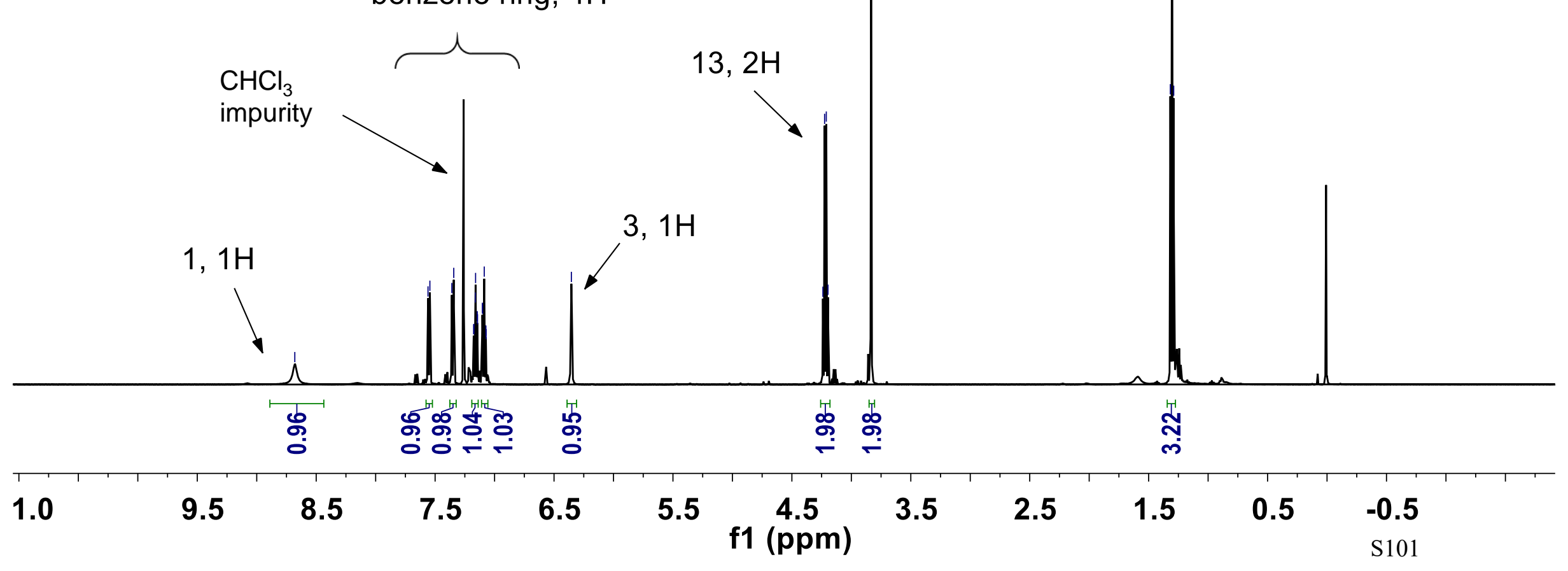




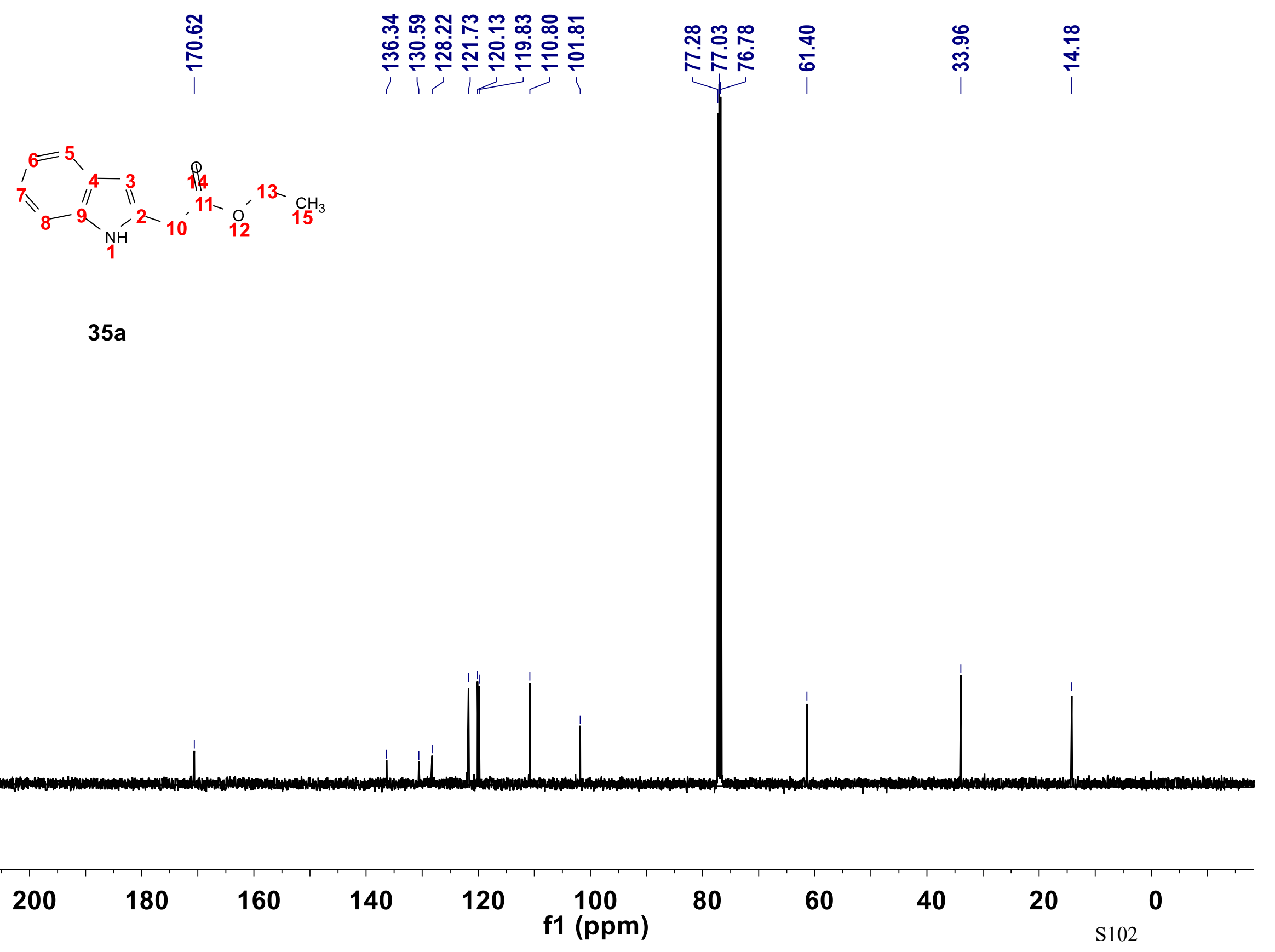




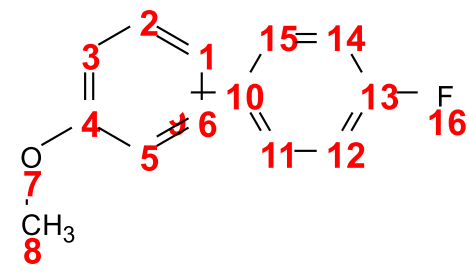

$36 a$

$8,3 \mathrm{H}$

benzene ring, $8 \mathrm{H}$

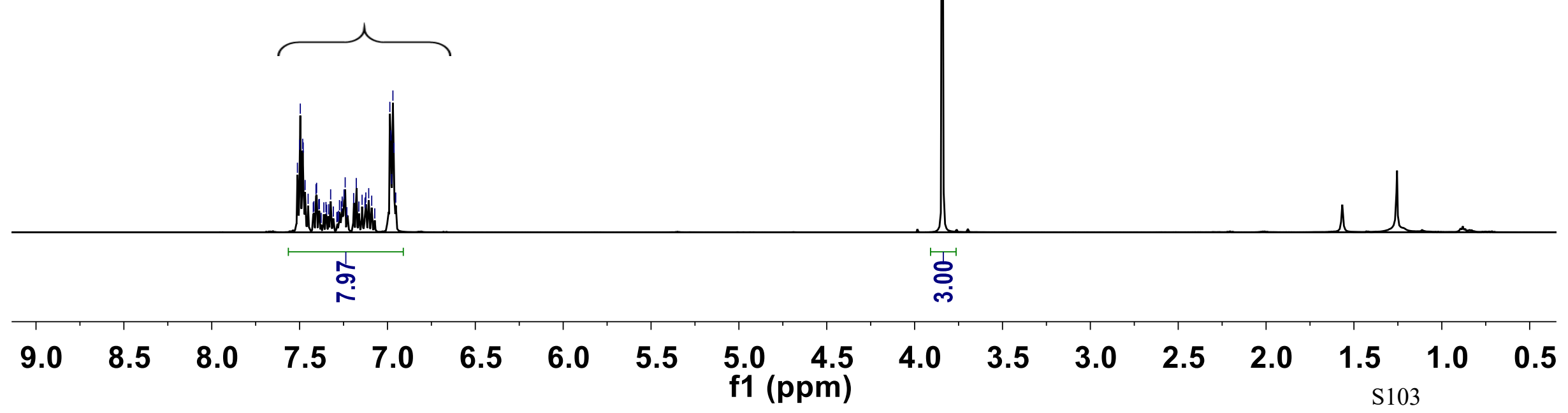




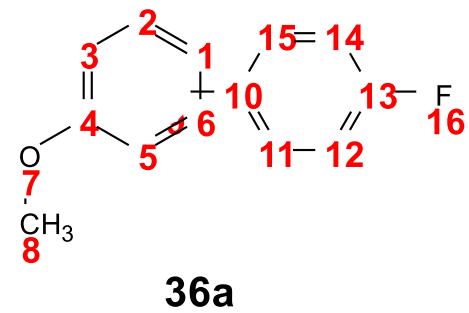

$36 a$

\begin{tabular}{|c|c|c|c|c|c|c|c|c|c|c|}
\hline 200 & 180 & 160 & 140 & 120 & $\begin{array}{l}100 \\
\mathrm{f} 1(\mathrm{ppm})\end{array}$ & 80 & 60 & 40 & 20 & ${ }_{4} 0$ \\
\hline
\end{tabular}




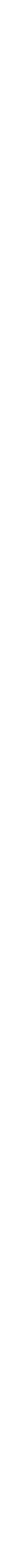



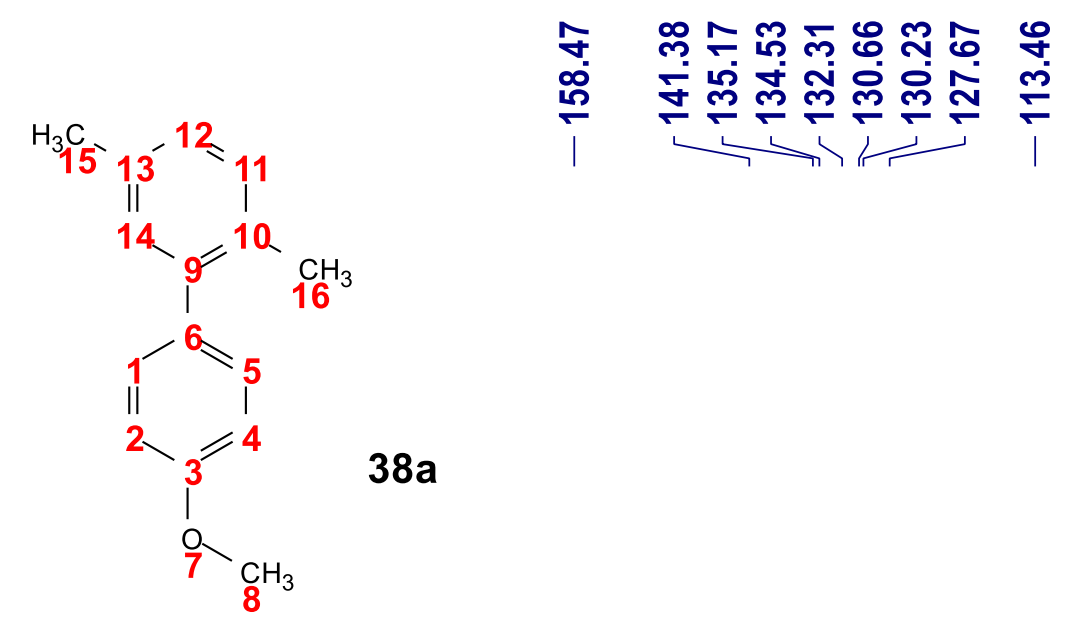

?

ชัษ

กึ่

유

$38 a$

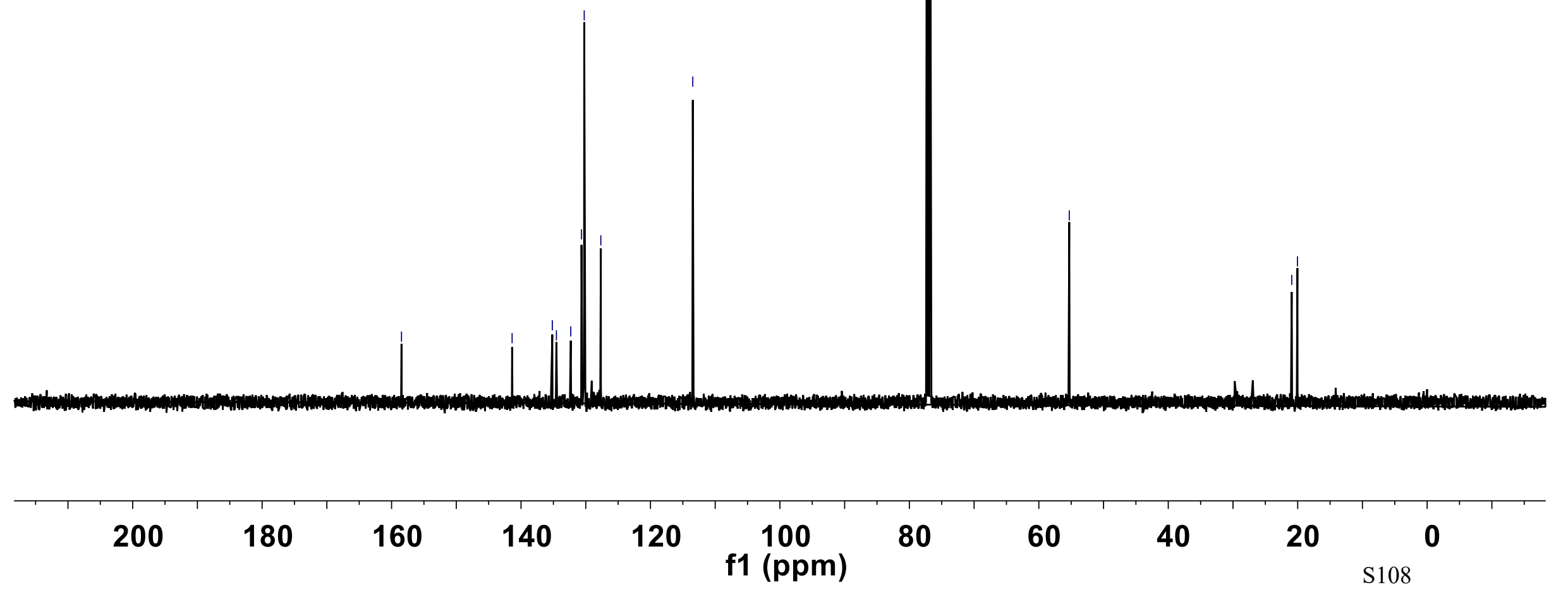




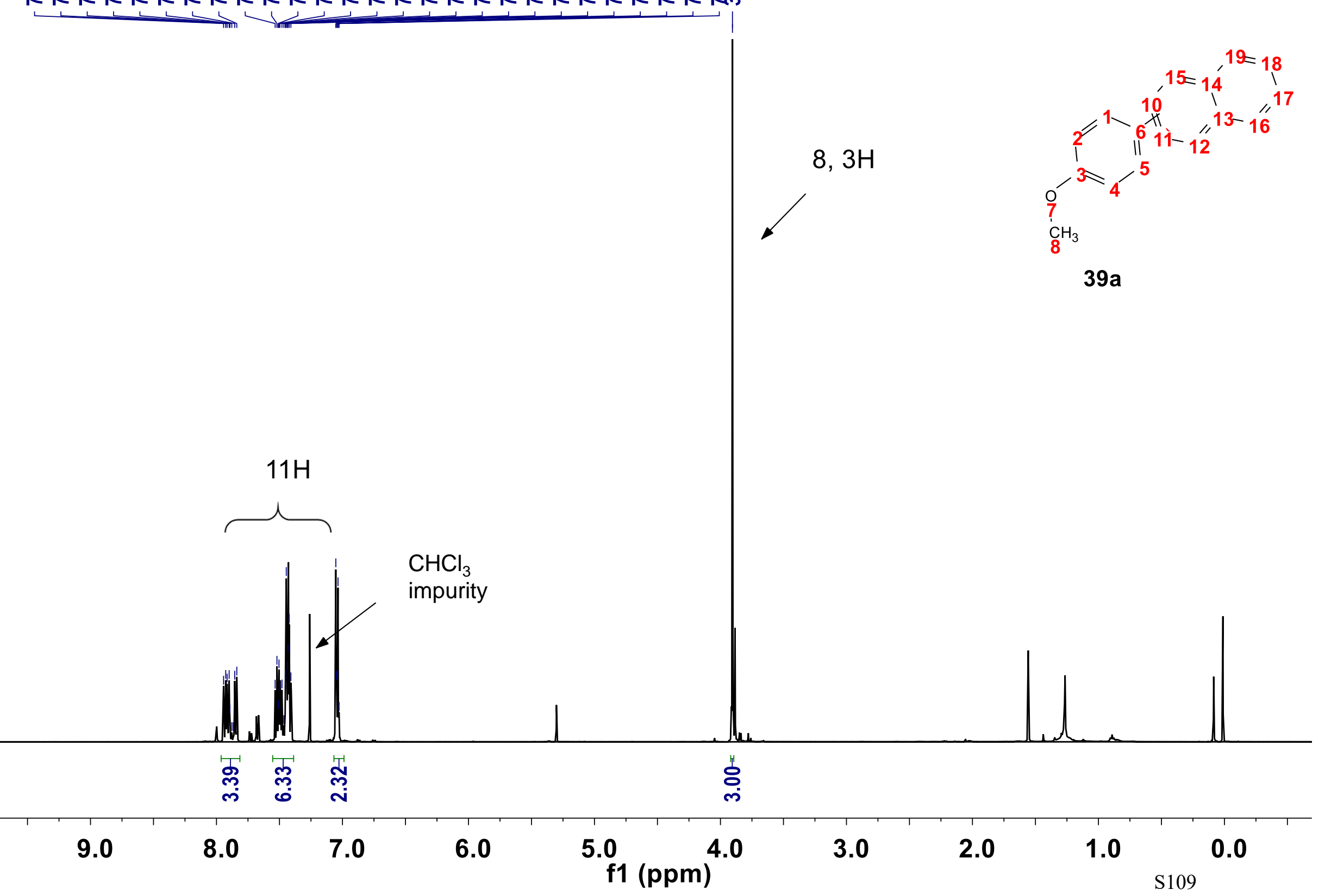




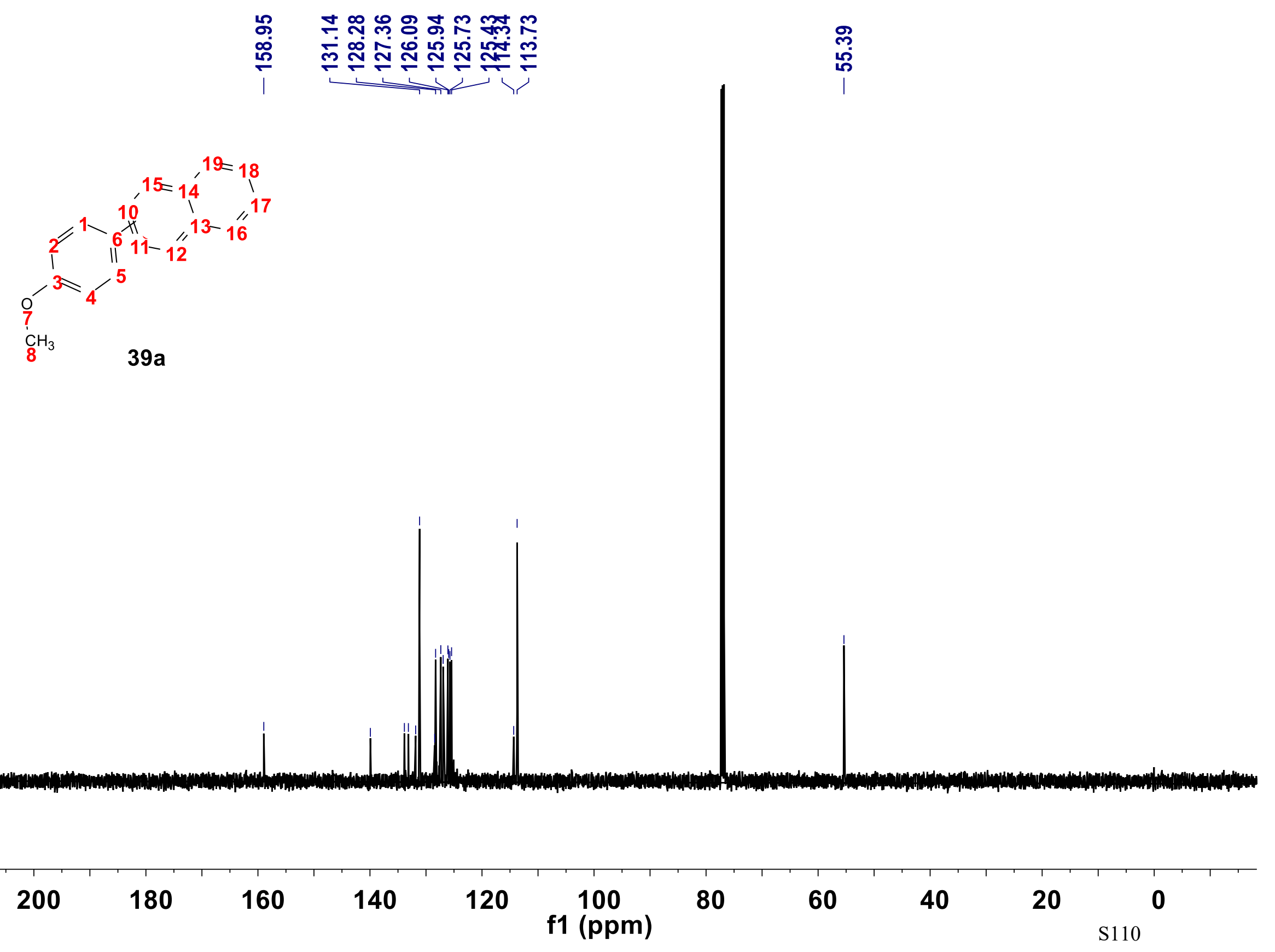




\section{References}

(1) Marcano, D. C.; Kosynkin, D. V.; Berlin, J. M.; Sinitskii, A.; Sun, Z.; Slesarev, A.; Alemany, L. B.; Lu, W.; Tour, J. M. Improved Synthesis of Graphene Oxide. ACS Nano 2010, 4, 4806-4814.

(2) Wei, H.; Huang, K.; Wang, D.; Zhang, R.; Ge, B.; Ma, J.; Wen, B.; Zhang, S.; Li, Q.; Lei, M.; Zhang, C.; Irawan, J.; Liu, L. M.; Wu, H. Iced Photochemical Reduction to Synthesize Atomically Dispersed Metals by Suppressing Nanocrystal Growth. Nat. Commun. 2017, 8, 1490.

(3) Kimling, J.; Maier, M.; Okenve, B.; Kotaidis, V.; Ballot, H.; Plech, A. Turkevich Method for Gold Nanoparticle Synthesis Revisited. J. Phys. Chem. B 2006, 110, 15700-15707.

(4) Wang, Y.; Zhao, D.; Ma, W.; Chen, C.; Zhao, J. Enhanced Sonocatalytic Degradation of Azo Dyes by $\mathrm{Au} / \mathrm{TiO}_{2}$. Environ. Sci. Technol. 2008, 42, 6173-6178.

(5) Liu, Y.; Wang, B.; Qiao, X.; Tung, C.-H.; Wang, Y. Iodine/Visible Light Photocatalysis for Activation of Alkynes for Electrophilic Cyclization Reactions. ACS Catal. 2017, 7, 4093-4099.

(6) Hu, C.; Peng, T.; Hu, X.; Nie, Y.; Zhou, X.; Qu, J.; He, H. Plasmon-Induced Photodegradation of Toxic Pollutants with $\mathrm{Ag}-\mathrm{AgI} / \mathrm{Al}_{2} \mathrm{O}_{3}$ under Visible-light Irradiation. J. Am. Chem. Soc. 2010, 132, 857-862.

(7) Houk, R. J.; Jacobs, B. W.; El Gabaly, F.; Chang, N. N.; Talin, A. A.; Graham, D. D.; House, S. D.; Robertson, I. M.; Allendorf, M. D. Silver Cluster Formation, Dynamics, and Chemistry in Metal-Organic Frameworks. Nano Lett. 2009, 9, 3413-3418.

(8) Ledo-Suárez, A.; Rivas, J.; Rodíguez-Abreu, C. F.; Rodríguez, M. J.; Pastor, E.; Hernández-Creus, A.;

Oseroff, S. B.; López-Quintela, M. A. Facile Synthesis of Stable Subnanosized Silver Clusters in Microemulsions. Angew. Chem. Int. Ed. 2007, 46, 8823-8827.

(9) De Cremer, G.; Coutino-Gonzalez, E.; Roeffaers, M. B.; Moens, B.; Ollevier, J.; Van der Auweraer, M.; Schoonheydt, R.; Jacobs, P. A.; De Schryver, F. C.; Hofkens, J.; De Vos, D. E.; Sels, B. F.; Vosch, T. Characterization of Fluorescence in Heat-treated Silver-Exchanged Zeolites. J. Am. Chem. Soc. 2009, 131, 30493056.

(10) Khutsishvili, S. S.; Vakul'skaya, T. I.; Kuznetsova, N. P.; Ermakova, T. G.; Pozdnyakov, A. S.; Prozorova, G. F. Formation of Stable Paramagnetic Nanocomposites Containing Zero-Valence Silver and Copper in a Polymeric Matrix. J. Phys. Chem. C 2014, 118, 19338-19344.

(11) Popovych, N.; Kyriienko, P.; Soloviev, S.; Baran, R.; Millot, Y.; Dzwigaj, S. Identification of the Silver State in the Framework of Ag-containing Zeolite by XRD, FTIR, Photoluminescence, (109)Ag NMR, EPR, DR UVvis, TEM and XPS Investigations. Phys. Chem. Chem. Phys. 2016, 18, 29458-29465.

(12) Mitrikas, G.; Trapalis, C. C.; Boukos, N.; Psyharis, V.; Astrakas, L.; Kordas, G. Size Distribution and EPR of Silver Nanoparticles in SiO Matrix. J. Non-Cryst. Solids 1998, 224, 17-22.

(13) Sun, T.; Seff, K. Silver Clusters and Chemistry in Zeolites. Chem. Rev. 1994, 94, 857-870. 
(14) (a) Tyrra, W. Silver(I) Fluoride and Related Compounds in Chemical Synthesis. Heteroatom Chem. 2002, 13, 561-566. (b) Giese, S. O. K.; Egevardt, C.; Rüdiger, A. L.; Sá, E. L.; Silva, T. A.; Zawadzki, S. F.; Soares, J. F.; Nunes, G. G. Catalytic Activity of a Titanium(IV)/Iron(II) Heterometallic Alkoxide in the Ring-Opening Polymerization of $\varepsilon$-Caprolactone and rac -Lactide. J. Braz. Chem. Soc. 2015, 26, 59-64.

(15) Mokar, B. D.; Liu, R. S. Regioselective Hydrations of 1-Aryl-3-en-1-ynes Using Gold and Platinum Catalysts: Selective Production of 2-En-1-ones and 3-En-1-ones. Chem. Commun. 2014, 50, 8966-8969.

(16) Beshai, M.; Dhudshia, B.; Mills, R.; Thadani, A. N. Terminal Alkynes from Aldehydes via Dehydrohalogenation of (Z)-1-iodo-1-alkenes with TBAF. Tetrahedron Lett. 2008, 49, 6794-6796. 